\title{
CERAMIC SHALES AND CLAYS OF IOWA
}

$$
\text { by }
$$

CHARLES S. GWYNNE 



\section{CONTENTS}

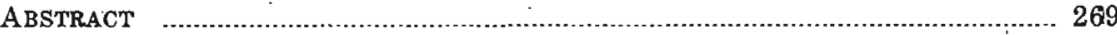

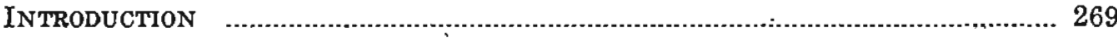

PREVTOUS STUDIES OF SHALES AND CLAYS OF IOWA ......................................... 270

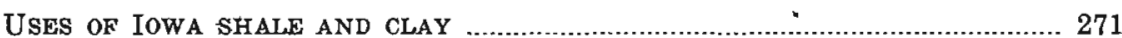

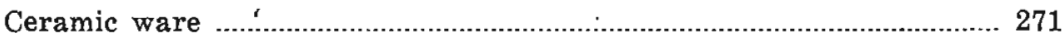

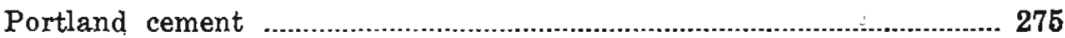

Mortar mix ……........................................................................... 275

Road surfacing and railroad ballast ......................................................... 275

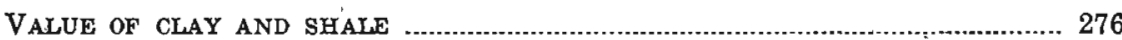

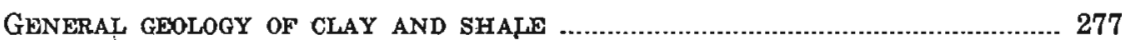

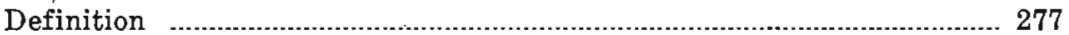

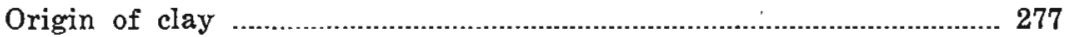

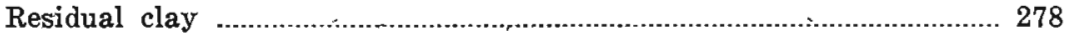

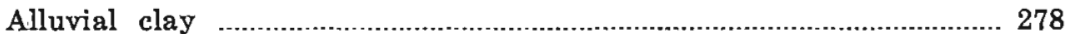

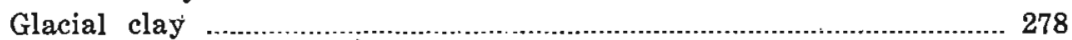

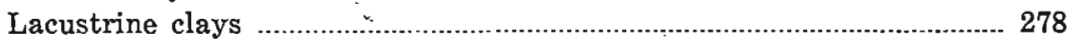

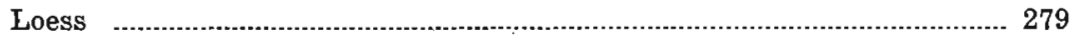

Marine and estuarine clays and shales ............................................ 279

Surface clays ................................................................................... 280

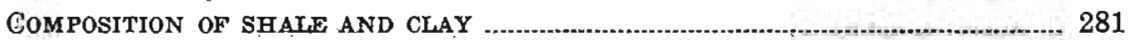

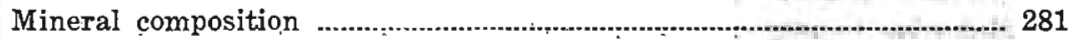

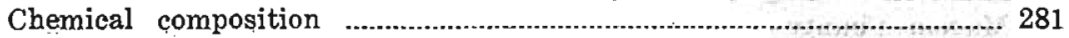

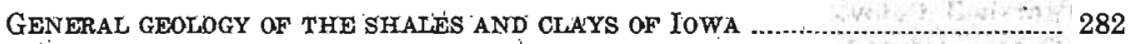

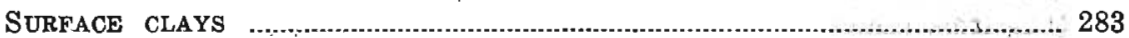

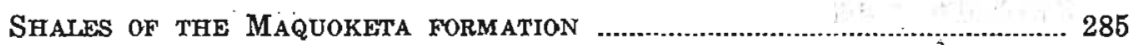

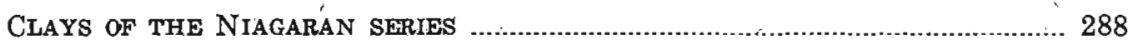

SHALES OF THE UPPER DEvONIAN SERIES .......................................... 289

Juniper Hill member, Lime Creek formation ................................... 289

The Sheffield formation ................................................................ 293

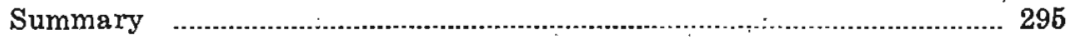

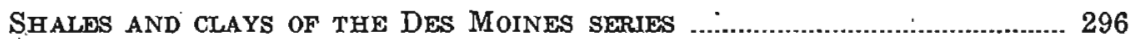

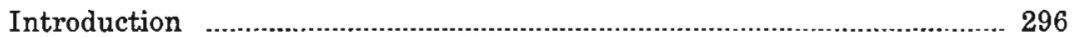

Extent …

Structure and relations ................................................................ 296

Thickness and stratigraphy ............................................................. 296

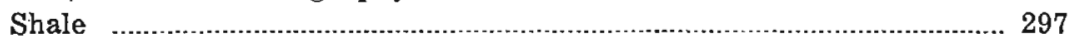

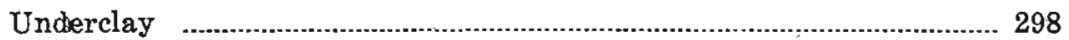

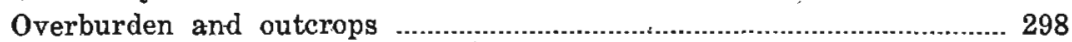




Appanoose County
Audubon County
Boone County $\ldots$
Calhoun County
Carroll County
Clinton County
Crawford County
Dallas County
Des Moines County
Franklin County
Greene County
Grundy County
Guthrie County
Hardin County
Harrison County
Henry County
Humboldt County


Shales and clays of the Cretaceous system

page

Extent

General stratigraphy and structure .................................................. 346

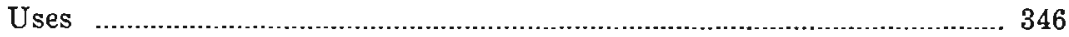

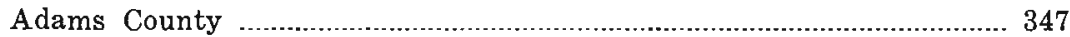

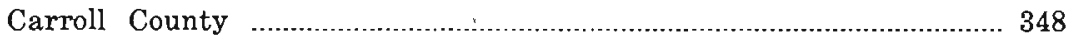

Cass County

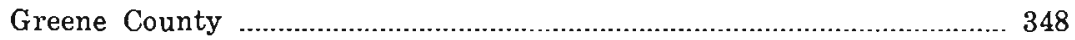

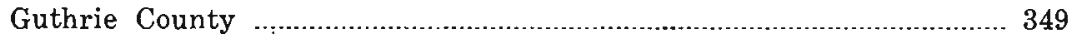

Montgomery County …....................................................................... 350

Plymouth County ........................................................................... 353

Pottawattamie County …................................................................... 353

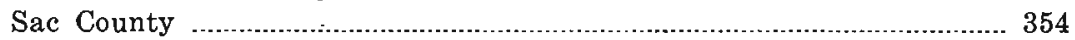

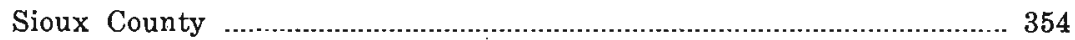

Woodbury County .......................................................................... 355

CeramiC TESTS ON IOWA SHALES AND CLAYS ............................................ 359

TESTS ON UNBURNED CLAYS AND SHALES .................................................... 360

Time of slaking ....................................................................................... 360

Volume shrinkage .............................................................................. 360

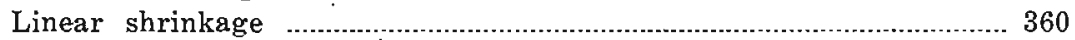

Water of plasticity .......................................................................... 360

Shrinkage water .................................................................................... 361

Pore water .............................................................................................. 361

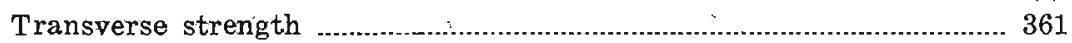

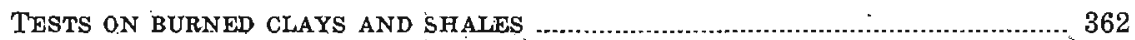

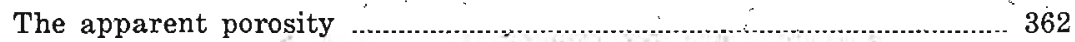

The volume change .............................................................................. 363

Apparent specific gravity …........................................................ 363

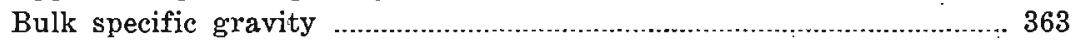

Absorption …............................................................................. 370

Hardness ............................................................................................... 370

Color changes and behavior in burning ..................................... 370

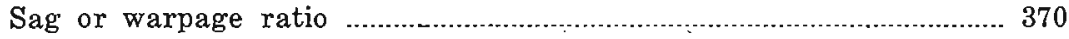

Summary of tests ....................................................................... 370

Chemical aNALYSES OF IOWA SHales AND CLAYS .................................... 371

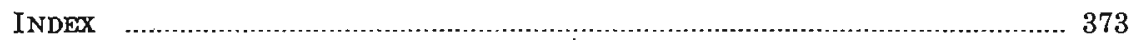


1. Geologic map of Iowa Facing 282

2. Des Moines series in Iowa Facing 296

Figure

1. Shale pit of the Rockford Brick and Tile Company, Rockford, Floyd County

2. Shale pit of the Goodwin Brick and Tile Company, Redfield, Dallas County

3. Channel sandstone at the pit of the Goodwin Brick and Tile Company, Redfield, Dallas County

4. Channel sandstone at the pit of the Goodwin Brick and Tile Company, Redfield, Dallas County. This view is adjacent to that of figure 3.... 306

5. General view north of planer, shale pit of the Adel Clay Products Company east of Redfield, Dallas County

6. Shale pit of the Adel Clay Products Company; east of Redfield, Dallas County, with planer in position against the shale deposit 307

7. Shale pit of the United Brick and Tile Company, Adel, Dallas County, showing characteristic bedding of the Des Moines series

8. Shale pit of the Standard Clay Products Company, now the Oskaloosa Clay Products Company, Harvey, Marion County

9. General view of exterisive abandoned workings in the shale pit of the Morey Clay Products Company, now the Ottumwa Brick and Tile Company, Ottumwa, Wapello County

10. Gypsum above the shale pit of the Vincent Clay Products Company, near Fort Dodge, Webster County

11. Thick glacial drift and channel sandstone in the shale pit of the Kalo Brick and Tile Company, Kalo, Webster County (1935)

12. Interbedded Cretaceous sandstone and clay southeast of Red Oak, Montgomery County

13. Shale pit of the Sioux City Brick and Tile Company, at Sergeant

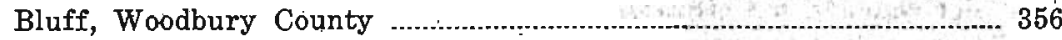

14. Shale pit of the Sioux City Brick and Tile Company at Sioux City, Woodbury County 


\title{
CERAMIC SHALES AND CLAYS OF IOWA
}

\author{
BY - CHARLES S. GWYNNE
}

\begin{abstract}
In this paper fundamentals of the geology and technology of the shales and clays of Iowa are dealt with. The uses, mineral composition, manner of occurrence and origin of these deposits are first considered. The distribution and character of the most important geologic units containing ceramic shales and clays are then described. Most attention is given to the Pennsylvanian Des Moines series, which underlies much of the central and southern parts of the State, and which is accessible at many places. Appropriate attention is given to other shale and clay horizons, the materials of which are used by ceramic plants. These include the surface clays, and the shales occurring in the Juniper Hill member of the Devonian Lime Creek formation, the Devonian Sheffield formation and the Cretaceous system. The shale of the Ordovician Maquoketa formation and the clay of the Silurian Niagaran series of northeastern Iowa are also considered, since these materials have either recently been used or their use considered.

Samples of these shales and clays were secured most of them from the pits of producing plants, and a few from natural outcrops: Thirty-six of these have been tested by methods recommended by the Standards Committee' of the American Ceramic Society and the data are included. While those tested have been found to vary somewhat in their ceramic properties, most of them are shown to be suitable for the manufacture of heavy clay products such as brick and tile. Forty-five chemical analyses of shales and clays are included, through the courtesy of cement manufacturers.
\end{abstract}

\section{INTRODUCTION}

Many of the shale and clay deposits of Iowa are suitable for the manufacture of ceramic ware such as brick, drain tile, building tile and pottery. They were used by the Indians in the making of pottery and by the earliest settlers in the making of brick. Over the past few decades the annual value of the ware produced has averaged well over a million dollars. In more recent decades they have also been used in great amount in the manufacture of portland cement, the annual value of which also runs into millions of dollars. Thus these materials, widespread and easily available, have demonstrated their suitability and their value, and must be considered an important mineral resource of the State. The wealth produced by the brick, tile and pottery plants of the present and the past, and by the cement plants, would be nonexistent were it not for these raw materials.

In spite of their abundance, the origin, the way in which they occur and the physical characteristics of these materials are none too well known to many citizens. Much has been written regarding them in the past. Volume 14 of the Iowa Geological Survey in particular dealt with them exhaustively. This, however, was pub- 
lished 40 years ago. Since that time, while the geology of the shales and clays has not changed, much has been learned concerning them. In addition the clay-working industry has undergone great changes in the number of plants; the raw material used, the methods of manufacture and in other phases. In view of such facts it seems reasonable that a description of these deposits and of associated matters related to their use should be of value to citizens of the State and to others. This paper is intended as such a description.

It is intended to make it rather non-technical, so that persons without acquaintance in the field of geology may acquire a reasonable understanding of the matters under discussion. 'It is hoped that the report will be of value to the clay products manufacturer or worker, to those having. shale or clay deposits on their lands and to those having a general interest in the subject. Many of the shales and clays have been sampled and tested for ceramic properties in the course of this study, and the results of the tests are described. This part of the report, of a more technical nature, should be of particular interest to the manufacturer of clay products.

Following consideration of the previous writings on the shales and clays of Iowa and of the history of their uses, the geology and mineralogy of shales and clays in general will be described. The general geology of the shales and clays of the State will next be considered, followed by sections devoted to each one of the shale or clay producing horizons. In those sections such matters as the extent and thickness, depth beneath the surface, character, and associated rocks for each producing horizon will be considered. Particular attention will be paid to descriptions of the material of the shale pits of the plants which are at present operating. Finally the tests made on samples taken from operating pits will be described, as will the results. Information regarding the extent of the industry will also be introduced.

\section{PREVIOUS S'TUDIES- OF SHALES AND CLAYS OF IOWA}

The Iowa Geological Survey has throughout its existence devoted a proportionate part of its work to consideration of the shale and clay resources of the State. "The results of the studies enter into many of the publications of the Survey, beginning with Volume 1, appearing. in 1892, and continuing through the most recent one, Volume 37, published in 1941.

During these years the Survey has completed reports on the geology of most counties of the State. Each of these describes the 
geology of the county including that of the deposits containing shale and clay. The economic geology is also described, and in these sections of the reports the ceramic industry of the county is dealt with, including a discussion of its raw material, the plants in operation, their equipment and other pertinent subjects:

The mineral production in Iowa from yéar to year has also been reported in various volumes. These mineral production reports are concerned chiefly with matters such as the annual value of the products and changes in the industry.

The most complete report on the clay and shale resources and industry of Iowa is that of Volume 14 of the Survey, published in 1903. This includes the following sections:

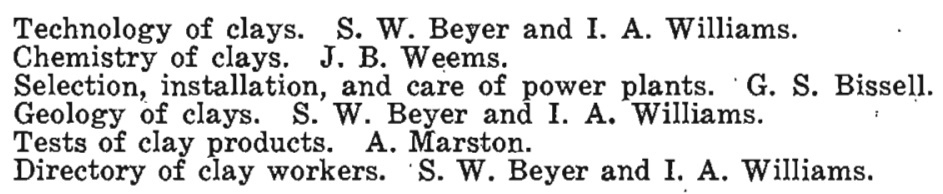

This report was thorough and dealt with some matters which will not be considered here. In particular, no attempt will be made to describe equipment and methods here.

The refractory and semi-refractory shale and clays of Iowa were investigated by Galpin ${ }^{1}$ in an attempt to locate commercial deposits of high grade refractory materials. He has described the occurrence, characteristics and ceramie properties of those shales and clays which were thought to have possibilities in the manufacture of refractory ware. The properties of the known Iowa refractory clays had previously been reported upon by Beecher. ${ }^{2}$

Publications of the Survey have been drawn upon freely in the preparation of this report. In addition to those mentioned above much use has been made of the geologic map of the State. ${ }^{3}$ This map provides the best information with regard to the areal distribution of the shale and clay-bearing formations of the bedrock over most of the State.

\section{USES OF IOWA SHALE AND CLAY}

Ceramic ware. Shales and clays have proven to be an important resource of Iowa almost since its earliest settlement, for.with the settlement there developed a brick and tile industry dependent upon

\footnotetext{
IGalpin, S. L., The geology of the more refractory clays and ghales of Iowa: Iowa Geol Survey, vol. 31, pp. 53-91, 1925.

"Beecher, M. F., An investigation of the Iowa fire clays: Engineering Experiment Station, Iowa State College, Bull. 40, 1915.

'Tester, A. C., Geologic map of Iowa, Iowa Geol. Survey, 1937.
} 
these materials. Tile was needed for drainage, brick for construction of paved city sidewalks and streets, brick and later building tile, for construction of dwellings and other buildings, and sewer pipe for construction of sewage systems. Pottery and stoneware plants also were built. Shale and clay were even burned to produce a rock-like material useful as railroad ballast in parts of the State where other forms of ballast were lacking. The ceramic industry became extensive, and in 1902 there were 329 large and small producers of clay products scattered about the State. Most of these were small plants and usually supplied a restricted local demand, particularly for brick and drain tile.

During the past three decades the number of ceramic plants in Iowa has gradually decreased until at present there are only approximately 28 plants operating or in condition to operate. These are engaged almost entirely in the manufacture of heavy clay products such as brick, drain tile, building tile and sewer pipe. The manufacture of pottery and stoneware has almost ceased. One small plant has, until recently at least, made flower pots and a few others have made art pottery. Occasionally plans arise for extensions of the pottery industry on a small scale, but this is not of great significance in the use of the shale and clay resources.

While the number of companies engaged in the manufacture of clay products has decreased greatly, the value of the annual production has increased and continues large. In 1929 it amounted to a total of $\$ 5,791,195$. It decreased in subsequent years, but has more recently again mounted as shown by the following table: ${ }^{4}$

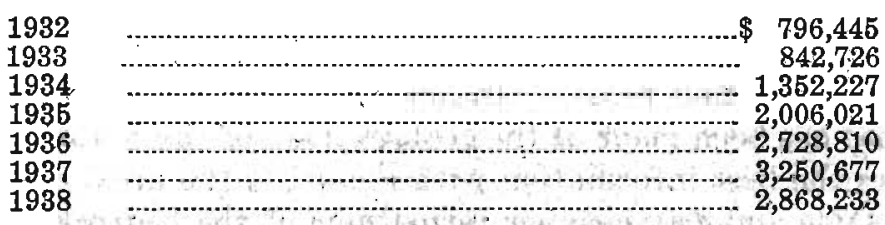

These changes in the distribution and extent of the industry have been accompanied by changes in the raw material used. Thirty years ago the surface clays were most widely used. Gradually the shales and clays of the bedrock have become the principal raw material, although surface clay is used in part at many of the plants.

The decrease in the number of clay products plants has obviously not been due to the exhaustion of supplies of raw materials. Clay and shale suitable for the manufacture of the more common wares

\footnotetext{
1941.

¿Hershey, H. G., Mineral production in Iowa-1988-1988: Iowa Geol. Survey, vol. 87, p. 886,
} 
are available in Iowa, as they are in other states, in enormous quantity. Other factors have played a greater part in the changing structure of the ceramic industry of Iowa. These include the cost of the shale and clay, dependent in turn upon matters such as the amount of overburden which must be moved, the presence or absence of non-ceramic materials sueh as limestone or sandstone interstratified with the shale, and the general cost of pit operation and hauling; location of plant with respect to markets; cost of plant operation; and the quality of the product. The history of the industry in other midwestern states has been in many respects similar to that of Iowa for the same general reasons.

Iowa lacks proved deposits of shale and clay suitable for the manufacture of higher grade products such as fire brick and china. Some localities in other midwestern states possess advantages in the manufacture of the heavy clay products, not of superior shales or clays, but of better transportation facilities or of more extensive markets.

The companies at present (1942) operating in Iowa are listed below, together with the location of their plants, the kinds of ware produced and the monthly capacities where known.

Iowa Brick and Tile Manufacturens, Products and Capacities

\begin{tabular}{|c|c|c|}
\hline Company and Location & Products & $\begin{array}{l}\text { Monthly } \\
\text { Production } \\
\text { Tons }\end{array}$ \\
\hline $\begin{array}{l}\text { Adel Clay Products Co., } \\
\text { Redfield, } \\
\text { Dallas County }\end{array}$ & $\begin{array}{l}\text { Common brick, face brick, struc- } \\
\text { tural clay tile, unglazed facing. } \\
\text { tile, drain tile. }\end{array}$ & $(1+2)=6$ \\
\hline $\begin{array}{l}\text { Carlisle Brick and. Tile Co. } \\
\text { Carlisle, Warren County }\end{array}$ & $\begin{array}{l}\text { Common brick, face brick, struc- } \\
\text { tural clay tile, unglazed facing } \\
\text { tile: }\end{array}$ & 8 \\
\hline $\begin{array}{l}\text { Clermont Brick and Sand Co. } \\
\text { Clermont, Fayette County }\end{array}$ & Common brick; drain tile. .......... & \\
\hline $\begin{array}{l}\text { Des Moines Clay Co.. } \\
\text { Des Moines, Polk County }\end{array}$ & Common brick, faee brick. ........ & 2,500 \\
\hline $\begin{array}{l}\text { Centerville Clay Products Co. } \\
\text { Centerville, Appanoose County }\end{array}$ & Common brick, face brick. & $1 ;, 800$ \\
\hline $\begin{array}{l}\text { Garrison Brick and Tile Co. } \\
\text { Garrison, Benton County }\end{array}$ & Common brick, drain tile. ........... & 400 \\
\hline $\begin{array}{l}\text { Gladbrook Press Brick and } \\
\text { Tile Co. } \\
\text { Gladbrook, Tama County }\end{array}$ & Common brick, face brick. ........ & 1,000 \\
\hline $\begin{array}{l}\text { Goodwin Tile and Brick Co. } \\
\text { Des Moines, Polk County }\end{array}$ & $\begin{array}{l}\text { Common brick, face brick, struc- } \\
\text { tural clay tile, unglazed facing } \\
\text { tile; drain tile. }\end{array}$ & 2,000 \\
\hline
\end{tabular}


Iowa Sewer Pipe and Tile Co. Drain tile, sewer tile, wall copDes Moines, Polk County

Johnston Clay Works

Fort Dodge, Webster County ing.

Common brick, face brick, structural clay tile, unglazed facing tile, drain tile, salt glazed brick and tile.

Kalo Brick and Tile Co.

Common brick, face brick, strucKalo, Webster County tural clay tile, unglazed facing tile, drain tile, salt glazed brick and tile.

Kimballton Brick and Tile Co. Common brick, drain tile.

Kimballton, Audubon County

Lehigh Sewer Pipe Co.

Lehigh, Webster County

Sewer pipe

Mason City Brick and Tile Co. Common brick; face brick, sewer Mason City,

Cerro Gordo County

brick, structural clay tile, unglazed facing tile, drain tile. ....

F. C. McHose \& Son

Nevada, Story County

Common brick, structural clay

Nelso'n Clay Works

What Cheer, Keokuk County

tile, drain tile.

400

Oskaloosa Clay Products Co.

Oskaloosa, Mahaska County

Harvey, Marion County

Common brick, tile and art pottery.

Ottumwa Brick and Tile Co.

Ottumwa, Wapello County

Redfield Brick and Tile Co. Redfield, Dallas County

Common brick, face brick, structural clay tile, salt glazed brick and tile.

1,800

Common brick, face brick, structural clay tile, unglazed facing tile, drain tile.

Common brick, face brick, structural clay tile, unglazed facing tile, drain tile.

Rockford Brick and Tile Co. Rockford, Floyd Countý

Common brick, face brick, sewer brick, structural clay tile, unglazed facing tile, drain tile. ... Common brick, face brick, sewer brick, structural clay tile, unglazed facing tile, drain tile. ....

Sheffield Brick and Tile Co. Sheffield, Franklin County

Sioux City Brick and Tile Co. Common brick, face brick, sewer Sioux City, Woodburry County brick, structural clay tile, unSergeant Bluff, Woodbury County glazed facing brick, salt glazed brick and tile.

United Brick and Tile Co. Adel, Dallas County

Common brick, face brick, unglazed facing tile, structural clay tile, drain tile.

Vincent Clay Products Co. Fort Dodge, Webster County

Common brick, face brick, structural clay tile, unglazed facing tile, drain tile, salt glazed brick and tile.

What Cheer Clay Products Co. Drain tile, sewer tile, wall copWhat Cheer, Keokuk County ing.

Winfield Brick and Tile Co. Common brick, drain tile. 
The structural clay products named in the foregoing are defined below:

Common Brick: A brick made primarily for building purposes and not especially treated for texture or color.

Face Brick: Brick made especially for facing purposes, usually treated to produce surface texture or made of selected clays or otherwise treated to produce a desired color:

Paving Brick: A brick with good abrasive resistance made primarily for street or walk paving.

Sewer Brick: A brick relatively chemically inert made primarily for sewer construction or sewer lining.

Floor Brick: A brick with properties similar to paving brick but manufactured with greater precision and usually treated to produce a desired color.

Structural Clay Tile: A hollow clay tile made primarily for building purposes and not especially treated for texture or color.

Unglazed Facing Tile: A hollow clay tile made primarily for facing purposes, usually treated to produce surface textures or made of special clays or otherwise treated to produce a desired color but without the addition of a surface glaze.

Drain Tile: A circular tile made primarily for land drainage of subsurface water.

Ceramic Glazed Brick or Tile: A brick or tile with surface glazing produced by the direct application of a glazing material to the surface.

Salt Glazed Brick or Tile: A brick or tile with surface glazing produced by condensation of a volatilized metallic salt on the surface.

Portland cement. The shales and clays of the State are also used in making portland cement, in the manufacture of which a considerable percent of argillaceous or clayey substance, as. well as limestone, is required. The composition of the limestone may be such that not much additional shale or clay is needed, but the percentage of shale or clay required may total as much as 25 percent if the available limestone is almost pure. Thus the cement plants of Des Moines, West Des Moines, Mason City and Davenport are important users of shale or clay in cement, although it is difficult to arrive at the value of the raw material used.

Mortar mix. Finely ground shale and clay are also used in the building industry as "mortar mix". This contributes to plasticity when added to the mortar in small amount. The mortar is said to "work" better, to smooth more easily and to fill small holes and crevices more completely. Value of the ground shale sold for this purpose in 1938 is believed to have totaled approximately $\$ 30,000$.

Road surfacing and railroad ballast. The production of railroad ballast by burning clay was a simple one. It consisted of piling up layers of clay and of old railroad ties and similar combustible material, and setting fire to the pile. The use of burned shale and clay as railroad ballast was discontinued many years ago. In recent decades, however, the partially burned shale and other refuse of coal mines has been widely used for road surfacing and for surfac- 
ing the shoulders of conerete highways, and possibly for railroad ballast. This refuse contains not only shale and clay from the mines, but also more or less associated coal. The coal ignites, possibly as a result of the heat generated in weathering of the coal or contained impurities, and the shale and clay are partially vitrified. The material serves usefully when better materials such as gravel and limestone are not available.

\section{VALUE OF CLAY AND SHALE}

The highest quality shales or clays, unprocessed and in bulk, are not expensive materials, and even those of lower quality but still limited in distribution are relatively low-priced. The following table $^{5}$ gives values for the clays which are sold in quantity in the United States.

Average values per short ton of various kinds of clay sold by producers in the United States, 1909-13 and 1925-34.

\begin{tabular}{|c|c|c|c|c|c|c|c|}
\hline Year & & $\frac{\mathrm{E}}{\mathrm{T}}$ & $\begin{array}{l}\text { Kaolin and } \\
\text { Paper Clay } \\
\text { United States }\end{array}$ & $\begin{array}{l}\text { Ball } \\
\text { Clay }\end{array}$ & $\begin{array}{l}\text { Slip } \\
\text { Clay }\end{array}$ & $\begin{array}{l}\text { Fire } \\
\text { Clay }\end{array}$ & $\begin{array}{c}\text { Stoneware } \\
\text { Clay }\end{array}$ \\
\hline $\begin{array}{l}909-13 \\
925-29\end{array}$ & $\begin{array}{l}\text { (average) } \\
\text { (average) }\end{array}$ & 군, & $\begin{array}{l}\$ 5.34 \\
8.45\end{array}$ & $\begin{array}{r}\$ 3.65 \\
7.67\end{array}$ & $\begin{array}{r}\$ 1.81 \\
5.41\end{array}$ & $\begin{array}{r}\$ 1.39 \\
2.76\end{array}$ & $\begin{array}{r}\$ 1.00 \\
2.12\end{array}$ \\
\hline & & & & $7: 91$ & & 2.38 & 1.93 \\
\hline & ……. & . & & & & 2.8 & 2.30 \\
\hline 932 & ........................ & 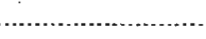 & 5.83 & 6.57 & 9.7 & 2.83 & 1.66 \\
\hline 33 & ……............... & ...................... & & 6.21 & 7.28 & 2.77 & 2.11 \\
\hline & & & & 6.73 & 7.00 & 2.90 & 1.77 \\
\hline
\end{tabular}

These values include cost of quarrying and possibly processing as well, and it is notable that even fire clay of marketable quality, higher in quality than that of Iowa, is not very costly. Stoneware clay, really a low-grade fire clay, has a still lower value.

Common shale and clay suitable for use in making heavy clay products has even less market value than stoneware clay if sold unprocessed. It has a greater market value when ground and sold in small quantities for special purposes, as for mortar mix or clay modeling, but the market for such purposes is limited. Kaolin and ball clay are white-burning clays used in high quality products such as chinaware, and slip clay is a clay of low fusibility used in glazes and as a binder in abrasives. They command a higher price because of their scareity. There is believed to be little or no prospect . of any of these more valuable clays being found in commercial quantity in Iowa.

STyler, P. M., and Metcalf, R. W., Clay: Minerals Yearbook 1985, p. 984, 1985. 


\section{GENERAL GEOLOGY OF CLAY AND SHALE}

Definition. Clay, from the ceramist's viewpoint, is a naturally occurring earthy substance which will mold when wet, retain its shape when dry, and harden to a rock-like substance upon cooling after being subjected to a sufficiently high temperature, a process known as burning or firing. Shale is similar in properties, but is commonly more compact and rock-like, stratified, and occurs in more or less definite layers, usually beneath the subsoil. Shale, to the geologist, ${ }^{\circ}$ is a fine-grained, fissile, argillaceous, sedimentary rock characterized by rather fragile and uneven laminae and commonly a somewhat splintery fracture. In any case shale is generally considered to be a consolidated mud or clay, consolidated by pressure, or cementation, or both. There is obviously no sharp division between the consolidated and the unconsolidated clay.

Origin of clay. Clay originates through the breaking down of other rocks, and the individual particles of clay are the smallest produced in this breaking-down process. Most of the particles of clay originate through the natural process known as weathering. This process is in part a chemical one, brought about by the gases of the atmosphere, water, carbon dioxide, oxygen and possibly other constituents present in minor amount; and by the subsurface water with its content of dissolved carbon dioxide, oxygen, weak organic acids derived from the decay of vegetation, and occasionally weak inorganic acids derived from the weathering of minerals. Weathering is also in part a physical or mechanical process brought about by volume changes induced by chemical weathering and possibly by temperature changes, the freezing of water in cracks, and the splitting and prying action of plant roots.

Most of the minerals of the primary rocks such as granite are changed to other substances by this process. Some of these substances are soluble in water and are leached away. Others, insoluble and inert to further change and in particles of microscopic size remain, unless removed by running water, wind, or glacial ice. Some of the minerals of the primary rocks such as quartz are quite inert and remain essentially unchanged in the midst of the mass of clay-like material ${ }_{\text {th }}$ thus derived from the less inert minerals. The final product is essentially a clay, possibly containing quartz grains and insoluble weathering products such as limonite, a hydrated iron oxide.

\footnotetext{
Fay, A. H., A glossary of the mining and mineral indústry. U. S. Bar. Mines Bull. 95,
} p. 606,1920 . 
Residual clay. This weathering process just described will produce a clay-like mass from most rocks. Unless subjected to active erosion this product will rest upon the rock from which it was derived and will grade to it through less and less weathered material. Such material is known as residual mantle and as residual clay if it is high in clay. Commercial deposits of high grade white residual clay such as occur in North Carolina are derived from rocks lacking in iron-containing minerals. Such clays, in part because of their freedom from iron, can be used in the manufacture of high grade ceramic products such as china ware and porcelain. There are, however, extensive areas underlain by residual clay that have no great value because of the admixture of limonite, and grains and larger fragments of inert minerals and rocks. . Residual clays are unimportant in Iowa, although present above the bedrock in some places.

Alluvial clay. All other clay and shale deposits are derived chiefly from the clay of residual mantle, although a considerable proportion of the particles of clay-like size may have.been derived from the solid rocks, of the streams and bedrock by the erosive agents, particularly running water. Running water has great sorting power, whereby particles of one grain size are laid down together as the running water loses velocity. This leads to the formation of deposits of clay as well as of silt, sand and gravel along the valleys, particularly of the larger streams. Thus, deposits of alluvial clay are present along many of the rivers and smaller streams of Iowa and have been used to some extent in the manufacture of ceramic products. They constitute a type of transported mantle, as do the deposits made by glaciers, lakes and the wind.

Glacial clay. Glaciers, such as those which have in time past covered all of Iowa and much of the upper Mississippi and Ohio River basins, have left great deposits of clay mixed with particles of larger size. This glacial clay, till, or boulder clay, as it is variously called, is comprised chiefly of particles of clay size, but also contains considerable amounts of silt, sand, pebbles, cobbles and boulders in heterogeneous mixture. Much of this material has been freed from the bedrock by weathering but a considerable proportion is the result of glacial wear upon solid rock. Much of the subsoil of Iowa, visible in road and stream cuts, is glacial clay. It may be associated with deposits of sand and gravel formed by glacial meltwater.

Lacustrine clays. Lacustrine clays, another type of transported 
clay, are formed by the deposition of clay on lake bottoms. The lake may gradually be filled and, aided by other causes, finally disappear. The lacustrine clays thus come to be the mantle or subsoil beneath essentially level areas of greater or less extent. Lake plains of this origin are present in many places in the northern United States and Canada, but are of only small extent in Iowa. Such clays are used for ceramic purposes in some places.

Loess. The wind has deposited over great areas of Iowa, adjacent states, and other parts of the world, a blanket of silt and clay called loess. Much of this material in this region is believed to have been derived from glacial meltwater. As the ice melted, the flood plains of the larger rivers were repeatedly flooded. Silt and clay were deposited as the floods subsided. As the surface dried out the particles were swept up by the wind and dropped elsewhere. While the loess grains are for the most part silt size rather than clay, there is nevertheless usually a considerable proportion of clay present, either original or secondary, derived from the weathering: of the deposited material. In any case many occurrences are claylike and are used for ceramic purposes. They have been widely used in Iowa.

Marine and estuarine clays and shales. Most of the argillaceous rock in the bedrock of Iowa, that used by most of the ceramic plants, is marine in origin. It has been formed by deposition in the sea or in estuaries at times when the distribution of land and sea was far different than at present. The beds are interstratified with the hardened products of other sediments deposited in the ancient seas, including limestone, sandstone and conglomerate. The seas during times past have transgressed slowly over the continents many times and in them have been deposited the limy or calcareous ooze, mud or clay, sand and gravel that were subsequently to form the limestone, shale, sandstone and conglomerate respectively of the bedrock of today. Coal, another interstratified material, was formed as peat in ancient swamps. The coal usually lies upon an argillaceous material which is called an underclay. It lacks the stratified character of shale although it may grade to shale, has an irregular blocky or starchy fracture, and differs in its ceramic properties from the shales in that it burns at higher temperatures and produces ware that is some shade of buff rather than red in color. These underclays, or fire clays, as they are often called, have, presumably originated through changes in the subsoil of the areas in which the plants of the peat-forming areas grew. 
They are lower in iron and in elements which lower the fusibility of the ware made from them. They are more highly prized than most of the shales of the bedrock which can be used only in non-refractory, lower-burning products. If lacking in certain undesirable impurities, particularly iron in the form of the minerals limonite and pyrite, they can be used in the manufacture of refractory bricks and buff-colored brick and building tile; products which command a higher price than those made from the shale of the bedrock.

Surface clays. Deposits of any of the foregoing, but particularly those of glacial clay, alluvium, lacustrine clay and loess are changed at the surface by further weathering. Calcium carbonate (lime) is dissolved out, some minerals are changed to clay, and sand and silt grains are reduced in size. The result is a material referred to here as surface clay, which is plastic, usually dries without cracking, and can be burned to reasonably satisfactory brick and possibly tile. It has some advantages over other materials, one of them being that it can be worked practically from the sod down. The deposits, however, are not so thick, and the area which must be worked for clay is relatively large. Much surface clay also undergoes high shrinkage in drying, frequently with much cracking of the ware, and it does not burn as uniformly nor as quickly as shale. 
TABĹE 1

GENERALIZED GEOLOGIC SECTION OF IOWA

\begin{tabular}{|c|c|c|c|c|c|c|}
\hline System & Series & Group & \multicolumn{2}{|r|}{. Formation } & $\begin{array}{l}\text { Approx. } \\
\text { thiokness } \\
\text { (in feet) }\end{array}$ & Character \\
\hline \multirow{5}{*}{ Cretaceous } & \multirow{4}{*}{ Upper Gretaceoos } & \multirow{3}{*}{ Colorado } & \multicolumn{2}{|l|}{ Carlile } & $100+$ & Shale \\
\hline & & & Greenhorn & & $26-50$ & Limestone and shale \\
\hline & & & \multicolumn{2}{|l|}{ Graneros } & $100-200$ & Shale \\
\hline & & \multirow[t]{2}{*}{ Dakota } & & & $100-200$ & Sandstone and sbale \\
\hline & Lomer Cretaceous & & & & & \\
\hline Permian (?) & & & \multicolumn{2}{|c|}{ "Fort Dodge beds" } & Up to 50 & Gypsum and sbale \\
\hline \multirow{9}{*}{ Pennsylvanizan } & \multirow{4}{*}{ Virgil } & Wabaunsee & & & 300 & \multirow{2}{*}{ Limestone and sbale, } \\
\hline & & Shawnee & $\cdot$ & & $110-175$ & \\
\hline & & Douglas & & & $20-120$ & Sandy stale \\
\hline & & Peedee & & & & \\
\hline & \multirow{3}{*}{ Missouri } & Lansing & & & 25 & \multirow{3}{*}{ Limestone, shale and cosl } \\
\hline & & Kansas City & . & & $100-180$ & \\
\hline & & Pleassnton & & & $15-80$ & \\
\hline & \multirow{2}{*}{ Des Moines } & Appanoose-Henrietts & & 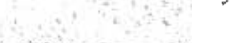 & $125-250$ & \multirow{2}{*}{ Shale, sandstone, coal and limestone } \\
\hline & & Cherokee & & $5^{7}$ & $350-450$ & \\
\hline \multirow{10}{*}{ Mississippian } & \multirow[b]{10}{*}{$?$} & \multirow{3}{*}{ Meramec } & \multicolumn{2}{|l|}{ Ste. Genevieve } & $30-50$ & Limestone, massive, with sandstone beds \\
\hline & & & St. Lonis & s. & $30-65$ & Limestone \\
\hline & & & Spergen $\mathrm{s}$ & 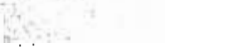 & $0-20$ & Limestone and dolomite \\
\hline & & & Waras & & 70 & Limestone and dolomite, cherty and shaly \\
\hline & & & Keoluk & - & $\cdot 70$ & Limestone and dolomite, cherty \\
\hline & & Osage & Burlington & & 70 & Limestone and dolomite, cherty \\
\hline & & & Gilmore City & & 45 & Limestone, oolitic \\
\hline & & & Hampton. & & $0-250$ & Limestone and dolomite, oolitic and cherty \\
\hline & & Kinderbook & Engliah River & & $0-25$ & Siltstone \\
\hline & & $?$ & Maple Mill & & $0-370$ & Sbale \\
\hline \multirow{6}{*}{ Devonian } & \multirow{5}{*}{ Upper Devonian } & & Sheffield & & 125 & Shale, thin dolomites \\
\hline & & & Lime Creek & 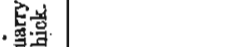 & $120-150$ & Limestone, dolomite and shale \\
\hline & & & Shell Rock & 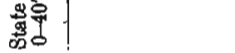 & $30-75$ & Limestone and dolomite \\
\hline & & 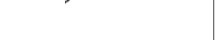 & Cedar Valley & & $90-150$ & Limestone \\
\hline & & 3 & Independence (?) & & $0-20$ & Shale \\
\hline & Middle Devonian & & Wapeipinicon & & $100-120$ & Limestone and dolomite, shale \\
\hline & & & Gower & & 100 & Dolomite \\
\hline & Niagaran & & Hopkinton & & $40-200$ & Doloninite : \\
\hline Sillurian & & & Kankakee & & 40 & Dolomite, cherty \\
\hline & Avexanarian & & Edgewood & & $6-45$ & Dolomite, arpilipceous \\
\hline & Cincinnatian & Richmond & Maquoketa & & $0-300$ & Shale, limestone and dolomite, eherty \\
\hline & - & & Dubu & uque & 30 & Limestone and dolomite \\
\hline & & & Galena & gartville & 80 & Limestone and dolómite \\
\hline & Mohawkian & 1 renton & Pross & & $135-180$ & Limestone and dolomite, cherty \\
\hline & & & Decorah & & 30 & Shale, and limestone \\
\hline Ordovelan & & Black River & Platteville & & 50 & Shale and limestone \\
\hline & Chazyan & & St. Peter & & $50-238$ & Sandg̣tone \\
\hline & & & - & Willow River & $75-90$ & Dolomite, sandy and cherty \\
\hline & Beekmantownian & & Prairie du Chien & $\begin{array}{l}\text { Root Valley } \\
\text { (New Richmond) }\end{array}$ & $20-25$ & Sandstone, dolomitic \\
\hline & & & & Oueots & $140-170$ & Dolomite, sandy and cherty \\
\hline & & & Trempealeau & $\left\{\begin{array}{l}\text { Madison } \\
\text { Jordan } \\
\text { Lodi } \\
\text { St. Lawrence }\end{array}\right.$ & $150-185$ & $\begin{array}{l}\text { Dolomite, sandy } \\
\text { Sandstone, dolomitic } \\
\text { Silitistone to sandstone } \\
\text { Dolomite, sandy }\end{array}$ \\
\hline Cambrian & St. Croixan & & Franconia & & 180 & Sandstone and dolomite, glauconitic \\
\hline & 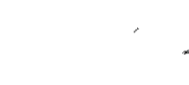 & & Dresbach & $\left\{\begin{array}{l}\text { Galesville } \\
\text { Eau Claire- } \\
\text { Mt. Simon }\end{array}\right.$ & 550 & Sandstone \\
\hline $\begin{array}{c}\text { Pre-Cambrian } \\
\text { (Huronian) }\end{array}$ & & & Sioux & & & Quartzite \\
\hline
\end{tabular}




\section{COMPOSITION OF SHALE AND CLAY}

Mineral composition. Shale and clay consist of grains or particles less than 0.004 millimeter in diameter, derived from many sources and from many kinds of pre-existing rocks and minerals. Shale and clay particles are those below a certain size, and are not of a specific composition or origin. Most of the particles are grains of the "clay" minerals, derived from the chemical weathering of other silicates. These clay minerals are soft, white, scaly minerals in flakes of microscopic size. There are commonly other clay-like minerals in clay deposits, including partially weathered mica and chlorite. Finally there are irregularly shaped grains of minerals such as quartz and feldspar which do not contribute to the clay-like character of the shale and clay. Such minerals commonly form the particles of silt size, ranging up to 0.06 millimeter in diameter which are found in most clay and shale deposits. Particles of sand size; ranging to 2 millimeters, are principally of quartz.

'There are several clay minerals or groups, but most of the common clay and shale is composed of members of the beidellitemontmorillonite group. Red or brown shales or clays contain appreciable quantities of the minerals limonite or hematite. Calcareous or limy shales and clays contain the mineral calcite, commonly referred to as lime. Dark gray and black shales and clays contain carbon derived from plant fragments. Pyrite is present in nodules and small crystals in many shale and clay deposits.

Shales and clays also contain a variable amount of extremely fine material known as colloidal matter. The clay minerals and the colloidal matter are principally responsible for the plastic propexties of these substances.

Chemical composition. The clay minerals are primarily hydrated aluminum silicates composed of the elements hydrogen, oxygen, alyminum and silicon, and some of them contain in addition smali amounts of the elements calcium, magnesium, iron and potassium in their composition. Micas and feldspars are aluminum silicates, containing in addition to silicon; oxygen and aluminum, small amounts of elements such as potassium, sodium, calcium, magnesium and iron. Quartz is silicon dioxide, hematite is iron oxide, and limonite is hydrated iron oxide.

A deposit of shăle or clay may thus range in chemical composition from that of a hydrated aluminum silicate to one containing relatively important amounts of iron, magnesium, calcium, sodium and potassium. The presence of these latter contributes to the low 
burning point of the material. Shales and clays free from those elements have a high burning temperature and produce a white product. Clays high in silt or sand generally are high in silicon dioxide. Chemical analyses of shale and clay are given at the end of this paper.

\section{GENERAL GEOLOGY OF THE SHALES AND CLAYS OF IOWA}

Directly beneath the topsoil of most of Iowa there are the materials making up the soil and subsoil, commonly known as mantle. These include chiefly loess, glacial clay and alluvial clay, but sand and gravel are present in considerable amount. Beneath these is the solid rock or bedrock containing the extensive deposits of shale and clay which are most widely used today. For an understanding of the distribution and relations of the shale and clay of the bedrock, it is believed advisable to consider briefly the geology of the State as a whole.

With the exception of a small area in the northwestern corner, the bedrock beneath the mantle is sedimentary rock. As already noted in the discussion of the origin of shales and clays, the beds

- of which this sedimentary rock is composed were originally laid down as sediments in shallow seas, which at various periods have covered the respective areas. The sediments have since hardened and consolidated to varying degrees due to the pressure of overlying beds and the cementation by substances deposited by ground water.

These sedimentary rocks are in broad sheets or lenses, some of great areal extent, one above the other, and are for the most part limestone, shale and clay, and sandstone. Except for those at the top beneath considerable areas in the western counties, they have the form of a shallow trough, the axis of which plunges gently southwestwardly from Winnebago County. Because of this structure the areas of outcrop or surface distribution of the various units are arranged in irregularly shaped belts of varying width which trend from the northwest to the southeast across central and eastern Iowa. They dip on the average approximately 8 feet to the mile. The older units, those at the bottom of the column, are at the surface in the northeastern corner of the State, and successively younger ones are at the surface toward the southwest. 


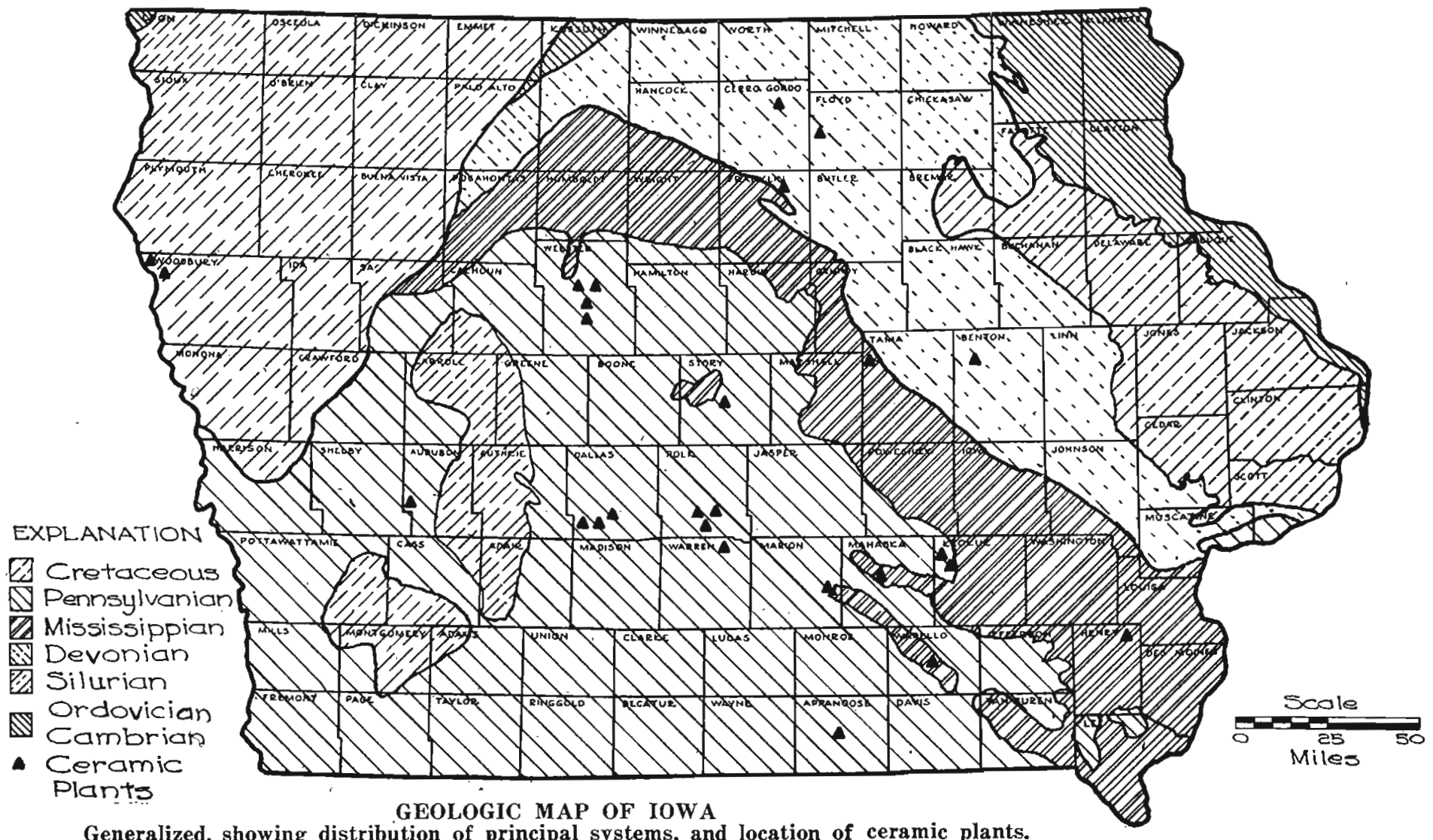

Generalized, showing distribution of principal systems, and location of ceramic plants. 

The geologists have given appropriate names to eras and periods of earth history, and refer to the rocks formed in eras and periods as sequences and systems respectively. The systems are further subdivided into series and formations. The accompanying generalized geologic map, plate $I$, shows the surface distribution of the geologic systems at the top of the bedrock in Iowa. The columnar section, table 1 , gives generalized information regarding the subdivisions, their thicknesses and character.

There are many shale beds in the section beginning near the bottom with the Platteville formation of the Ordovician system. Many of these are not suited to ceramic uses because of high lime content or the presence of interbedded limestone. Others are too thin or lie beneath thick overburden. The particularly important ones, used widely in the ceramic industry and in some cases in the cement industry, are:

The Juniper Hill member of the Lime Creek formation of the Upper Devonian series.

The Sheffield formation of the Upper Devonian series.

The Des Moines series.

The Cretaceous system.

The Maquoketa formation is of less importance, and the Niagaran series is only of interest because of the presence of whiteburning clays. Each of those named in the foregoing will be considered in the following pages.

These formations usually are exploited along valley sides, because the mantle overburden is least in such localities. They are thin because so much has been removed in the process of valley development. Where valleys are numerous, many of them deep, and where the mantle is thin, there may be many outcrops of the bedrock in a single county. Outcrops of the bedrock are absent in other counties in which the mantle is thick and the terrain but slightly eroded. Well records or the records of mining operations are then the only source of information regarding them.

The distribution and character of each of these units containing shale and clay important to the ceramic industry will be described in subsequent pages. The use of surface clays will also be briefly considered.

\section{SURFACE CLAYS}

Surface clays, in a ceramic sense, are clays which lie below the top soil and which can be used in the manufacture of ceramic ware. Geologically, such clays are the products of the weathering of the 
underiying clayey mantle, which may be alluvium, glacial clay or loess. Some so-called surface clay is also derived from the softening and weathering of shale in the bedrock beneath.

The surface clays derived from alluvium, glacial clay and loess are widespread through Iowa. Loess and alluvium formed by the reworking of loess are believed to constitute the parent material of most of the desirable surface clay, although glacial clay is also important. Weathering acts to remove lime, to reduce the amount of silt, by changing silicates to clay and by slowly dissolving inert mineral particles, and to soften larger pebbles and grains.

As stated earlier, ceramic plants using surface clays were once widespread in Iowa, but advantages in the use of shale have led to the pre-emption of the field by larger plants that use shale. Shale occurs in much thicker deposits than desirable surface clays, is more uniform, handles better in pressing and drying, can generally be fired at a somewhat higher temperature, and produces a harder ware. Surface clays are at present being used in the manufacture of heavy clay products at Kimballton, Audubon County; Garrison, Benton County; Gladbrook, Tama County; and Winfield, Henry County.

The plant and pit of the Roxy Clay. Works are located on the south side of the valley of Indian Creek, approximately three-quarters of a mile south of Kimballton, in the NE1/4 SE1/4 sec. 30, Sharon Township, (T. 79 N., R. 36 W.), Audubon County. The pit is being extended into a spur of the valley, into material most of which is loess, approximately 9 feet thick. The loess lowest on the slope, adjacent to and partly underlying a small draw, is stated to be fat and plastic; used alone it has high shrinkage and produces brittle ware. Loess from higher on the slope is too silty for a good product when used alone and is believed less weathered than that from lower down. Six feet of weathered glacial clay, separated from the overlying loess by a sharp irregular contact, is also used; this is red, sandy and pebbly, and grades to yellow below. The proportions of these three materials are varied in accordance with results secured in presses and kilns.

The plant and pit of the Garrison Brick and Tile Works are immediately south of Garrison on the north side of the wide terrace of Hinkle Creek in the NW1/4 SE $1 / 4$ sec. 29, Jackson Township, (T. 85 N., R. 11 W.), Benton County. The raw material is brown silty alluvium, somewhat loess-like in character, up to 6 feet thick, resting upon gravel. It is stated to be not as smooth or soapy as shale, 
and to tend to rub when scraped and to mold well. The kilns are burned at approximately $1700^{\circ} \mathrm{F}$. with temperatures at the bottom as low as $1200^{\circ}$ and as high as $1800^{\circ} \mathrm{F}$. around the pockets. Several acres have been worked over in the winning of clay for this plant.

The plant and pit of the Gladbrook Brick and Tile Co. are on the south side of the valley of Wolf Creek, west of Gladbrook in the NE $1 / 4$ sec. 8, Spring Creek Township, (T. 85 N., R. 16 W.), Tama County. The surface clay in this case also is a yellow loess somewhat reworked by slope wash and leaching. It is stripped of topsoil and then excavated to a depth of 6 feet. The unburned ware produced from clay is said to be very fragile and to crack and check easily in the dryer. The clay is also very sticky, so that it requires more power in handling than shale. The kiln temperature in firing the clay is $1900^{\circ} \mathrm{F}$. Only bricks are made at this plant, as the clay cannot be very successfully used in the manufacture of drain and structural tile.

The Winfield Brick and Tile Co. with plant and pit southwest of Winfield on a tributary of Crooked Creek in the NE $1 / 4$ sec. 16, Scott Township, (T. 73 N., R. 5 W.), Henry County, is using a surface clay to a depth of approximately 8 feet. The material is principally loess with possibly some weathered glacial clay. The loess has been weathered and reworked by fluvial erosion.

\section{SHALES OF THE MAQUOKETA FORMATION}

The Maquoketa is the lowest and oldest formation in Iowa which has recently been used in the manufacture of clay products. It has an approximate maximum thickness of 300 feet, and is described by Beyer and Williams" as consisting of "a series of beds, mainly shales, varying much in color, composition and texture." The lower part is described as made up of thin fissile shales, with some earthy, non-laminated beds carrying fossils. The upper portion consists of plastic clay shales carrying occasional indurated fossiliferous bands near the top and passes into thin layers of impure earthy dolomite. These dolomite layers are transitional to the thickbedded Silurian limestone which lies above them. Most of the Maquoketa shale used recently in the ceramic plants is believed to have come from below the indurated fossil bands near the top of the formation.

This formation directly underlies the mantle in some part or parts of each of the following counties: Allamakee, Bremer, Clayton,

\footnotetext{
TBeyer, S. W. and Williams, I. A., The geology of clays: Iowa Geol, Survey, vol. 14, DD.
} $384-395,-1004$. 
Clinton, Delaware, Dubuque, Howard, Fayette, Jackson and Winneshiek. It is exposed in many places, and close to the surface in many more. It is overlain by the heavy-bedded Silurian limesone, which may be recognized by its buff color and tendency to form cliffs. Thus the steep slopes beneath the limestone ledges are underlain by the shale. A summary of the localities where these shales are or have been rather well exposed, according to Beyer and Wil$\operatorname{liams}^{8}$, is given below:

Clayton County.

Marion Township, in the $\mathrm{NE}^{1 / 4}$ sec. 18, 11/2 miles northeast of Elgin.

Cass Township, 11/2 miles northeast of Strawberry Point.

Lodomillo Township, 11/2 miles north of Edgewood; Bear Creek near Edgewood.

Sperry Township, in the NE1/4 sec. 33, on a tributary of Hewett Creek. Clinton County.

Numerous exposures in the northeastern part of the county.

Spring Valley Township, northern limit of Lyons; in the bluffs along Mississippi River.

Delaware: County.

Elk River Township, various places in the bluffs along Mississippi River.

Colony Township, along Little Turkey River and Elk Creek; sec. 3, the source of clay once used in a pottery at Colesburg.

Dubuque County.

The northeast part of the county in general, and a small area in the northwest.

Center Township, accessible at Kidder and Graf.

Vernon Township, accessible at Peosta.

Fayette County.

Clermont Township, bluff northeast of railway station at Clexmont.

Winneshiek County.

Many outcrops in the southeastern third of the county.

Washington Township, in the SW1/4 sec. 18; and in the SW1/4 see. 13.

One mile northeast of Fort Atkinson.

One and one-half miles southeast of Calmar.

At intervals along Turkey River as far north as Spillville.

Three ceramic plants have until the last decade or so used Maquoketa shale as raw material.

The Bellevue Clay Products Co. has until recent years operated a brick and tile plant at Bellevue, Jackson County. The pit of the company, located on the east side of a small tributary to Mill Creek in the NE1/4 sec. 19, Bellevue Township, (T. 85 N., R. 5 E.), exposed weathered Maquoketa shale, in two openings, for a distance of several rods, and to a height of approximately 25 feet. This was almost entirely a blue-gray argillaceous shale, weathered to clay. The bottom of the pit consisted of a layer of a few inches thick of hard, brown, ferruginous sandstone, with more argillaceous shale, essentially unweathered, below. Gypsum fragments, of the variety satin spar, were numerous on the weathered slopes. Any extension

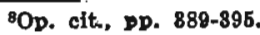


of this pit would encounter thick overburden, as the present workings are at the bottom of the valley and the slopes are steep. Brick, tile and flower pots were made.

The brick and tile plant of the Clermont Brick and Sand Co. is located at Clermont in Fayette County. Shale is trucked (1935) from a pit situated west of Elgin on the north side of the road to West Union and on the north side of a small valley tributary to Otter Creek, in the SW1/4 sec. 15, Pleasant Valley Township, (T. 94 N., R. 7 W.).

The pit face in 1935 was only a few rods wide, and material had been excavated a short distance into the steep hillside to a height of 18 feet. A foot or two of topsoil was removed and the underlying weathered shale, soft and plastic, was used in the plant at Clermont. The unweathered shale was gray brown, plastic when wet and slightly silty. The shale is overlain toward the top of the hill by the massive Silurian limestone which outcrops in thick ledges. It is obvious that this pit would soon encounter thick overburden, including the limestone, and would be difficult to operate.

The Postville Tile Works, which discontinued operations several years ago, also used Maquoketa shale as raw material in its plant as Postville. Surface clay, secured near the plant and believed to be of loessal drigin, was also used.

The shale was hauled by railroad from a pit on the south side of the valley of Otter Creek in the $\mathrm{SE} 1 / 4$ sec. 29, Pleasant Valley Township, (T. 94 N., R. 8 W.), Fayette County. The bottom of the pit was 20 feet above the base of the slope and the pit, which extended approximately 100 feet along the side of the valley, had a height of 20 feet. The material was entirely a blue, slightly silty shále, with a tendency toward fissility. The upper part, nearer the surface, was softened by weathering and stained brown. Here also ledges of Silurian limestone outcropped on the steep hillside above and it was apparent that extension of the pit into the side of the valley would soon encounter difficulty from this source.

The shale in these three pits is a uniform slightly silty material. Somew hat weathered shale near the surface was free of lime. Reasonably good ware could be made from the weathered shale, as demonstrated by the long operation of these and possibly other plants in the northeastern part of the State. Regardless of quality, the use of the Maquoketa shale is handicapped in many places by the presence of the thick ledges of Silurian limestone higher on the valley side. There are however considerable areas wherein the Maquoketa shale 
lies beneath gently rolling country, and from which the Silurian limestone is absent.

\section{CLAYS OF THE NIAGARAN SERIES}

The Niagaran series, although composed almost entirely of massive dolomitic limestone, has been shown to contain sporadic occurrences of high grade clay. These clays have been reported from Jackson, Clinton, Clayton and Linn Counties, which would place the deposits in the Hopkinton, the lower of the two formations comprising the series. They have not been used in the ceramic industry but would almost certainly find use if they were present in sufficient amounts. The deposits have been examined and the clays tested for ceramic properties by Galpin. ${ }^{8}$

Beds of the series in which these clays occur form the top of the bedrock benéath all or parts of Buchanan, Cedar, Clayton, Clinton, Delaware, Dubuque, Fayette, Jackson, Johnson, Jones, Linn, Muscatine, Scott and Winneshiek Counties. They contain, in addition. to the massive dolomitic limestones, small thicknesses of calcareous shale. These shales are unsuited to ceramic uses because of their lime content.

The high grade clay to which reference has been made occurs as crevice and cavity fillings in the limestone, in bodies the dimensions of which are never more than a few or several feet in any direction. According to Galpin this clay consists of material which was originally part of the shale layers of the formation. The layers were leached of the lime content by ground water, and the residual material accumulated in openings thus created in the limestone and in widened joints. The clay is hard, earthy and light gray in color, and burns to a light buff at a relatively high temperature.

Galpin has reported the occurrence of this clay at the following localities:

Clinton County,

Sec. 10, Deep Creek Township, 5 miles northeast of Goose Lake, on what is now the H. P. Heneke farm.

Jackson County.

In the $W^{1 / 2}$ sec. 35 , Iowa Township, $41 / 2$ miles east of Miles, on what is now the Ernest Jepsen farm.

Small amounits of clay from these occurrences were shipped to ceramic plants for trial, but the deposits have not been developed further because of the limited size. Other deposits have been reported from elsewhere in Clinton and Jackson Counties, and some

\footnotetext{
Op. cit., pp. 61-63.
} 
have been reported to the writer from Clayton and Linn Counties. None of these is believed of commercial size. Other occurrences may be discovered, but unless they are in much larger deposits they are not likely to be exploited.

\section{SHALES OF THE UPPER DEVONIAN SERIES}

The Lime Creek and Sheffield formations of the Upper Devonian series contain shale suitable for the manufacture of ceramic products.

Juniper Hill member, Lime Creek formation. The Lime Creek is divided into three members. ${ }^{10}$ The two higher, the Owen and the Cerro Gordo, total approximately 90 feet in thickness, and consist principally of limestone and calcareous shales. The Juniper Hill at the bottom is described by Stainbrook as "a homogeneous dark blue plastic shale, 90 to 100 feet thick and sparsely fossiliferous." Shale from the Juniper Hill member is used by the Mason City Brick and Tile Co. and by the Rockford Brick and Tile Co. for the manufacture of ceramic products. It is also used by the Northwestern States Portland Cement Co. and the Lehigh Portland Cement Co. as a source of the argillaceous material required in the manufacture of portland cement.

The Lime Creek formation forms the top of the bedrock of a broad belt which extends from southwestern Floyd County through Cerro Gordo, Winnebago and Hancock to eastern Kossuth County. The boundaries are not accurately known because of lack of outcrops and well records. The boundaries of the Juniper. Hill member also are not known but the upper surface presumably forms the top of the bedrock of approximately the northern half of this belt over much of the distance. It should therefore be present beneath the mantle in approximately the area of the counties and townships of table 2. The mantle is thick in most of the area, and this, together with the nature of the material, leads to scarcity of outcrops. The formation furthermore varies somewhat in character, so one cannot be very certain of the extent of material suitable for ceramic purposes.

At Mason City the most complete and informative section is the pit of the Mason City Brick and Tile Company in the southwestern part of the city in sec. 17, Mason Township, (T.96 N., R.20 W.). A heavy clay products industry has been operated in this vicinity for

10Stainbrook, M. A., Stratigraphy of the Devonian system of the upper Miselsaippi Valley: Kansas Geol. Soc. Guidebook 9th Ann. Field Conf., pp. 256-258, 1935. 
many years by various companies and a considerable area' of ground has been worked over in the winning of the clay. The section differs somewhat from place to place, due not so much to changes in the character of the shale formation as to the relief of the bedrock surface, the dip of the strata, and the depth of weathering.

TABLE 2

\section{Approximate Distribution of the Juniper Hill Member by Counties and Townships}

Kossuth County

Southern two-thirds of German.

Northern half of Buffalo.

Winnebago County

Southern two-thirds of Grant.

Southern two-thirds of Linden.

Southern half of Forest.

Southern third of Mount Valley.

Hancock County

Northern half of Bingham.

All except southwestern sixth of Crystal.

All of Madison and Ellington.

Northeastern corner of Britt.

Northern half of Garfield.

Northern half of Concord.

Cerro Gordo County

All except northeastern corner of Grant.

Southwestern corner of Lincoln.

Northern two-thirds of Clear Lake.

All of Lake and Owen.

Southern two-thirds of Mason.

Northeastern third of Mount Vernon.

Northern two-thirds of Bath.

Floyd County

Northeastern third of Dougherty.

Western half of Rockford.

Northwestern quarter of Scott.

The section exposed by operations in 1932 is described below :

Section: Masnn City Brick and Tile Company, Mason City, Cerro Gordo County, 1932
Member
Description
Weathered glacial till
Feet Inches
4 Clay, yellow in color and evidently derived from beds containing limestone, as it contains many limestone fragments much softened by weathering.
3 Shale, silty, yellow brown as a result of weathering $(\mathrm{T})^{11}$ Shale, silty, blue gray, very plastic when-wet, contains three layers of calcareous fine-grained sandstone up to 18 inches in thickness. (T)
$1 \quad$ Shale, silty, blue gray, plastic when wet, only vaguely stratified; contains more silt or sand in the lower part.

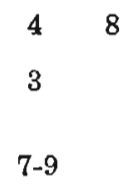

Thickness

11Ceramic tests were made on a sample from this member and from all others marked "(T)". Results of tests are given in the section Tests on Iowa Shales and Clays. 
Members 4 and 5 constituted the overburden at that time. The shale from member 2 could not be salvaged and the entire thickness of this member was therefore discarded and piled back in the pit. Members 1 and 3 were being used in the proportion of eight to one.

By 1942 the workings had been extended several hundred feet approximately southeast of the site of the section already described. The section, described below, was much like the one exposed 10 years earlier.

Section: Mason City Brick and Tile Company, Mason City, Cerro Gordo County, 1942

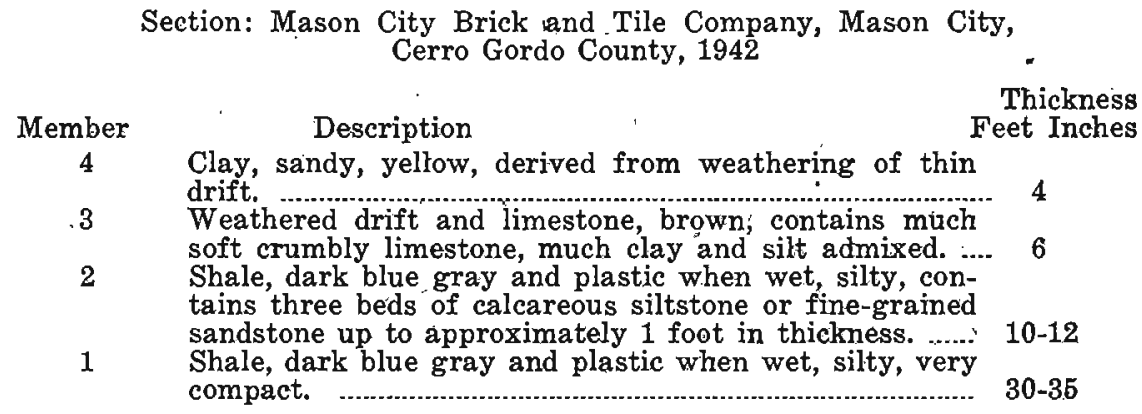

Members 1 and 3 are used in the manufacture of the ceramic ware. Members 2 and 4 are waste. Member 1 is so hard that blasting is employed to break it down. This material is described ${ }^{12}$ as quite plastic. When mixed with water to the right consistency it becomes quite slippery. It goes through the auger machine and dries very easily as compared to most clays. . After forming, the pieces are easily handled without deforming and dry easily without cracking. The clay forms a dense red-brown body when fired from $1900^{\circ}$ to $2000^{\circ} \mathrm{F}$. At temperatures above $2000^{\circ}-\mathbf{F}$., it is apt to deform or melt. Little or no difference in the properties of the shale throughout the section has been found.

Extensive workings at this locality with a large amount of material removed has resulted due to the large industry which has existed in the vicinity. There were at one time seven ceramic plants, whereas there are now (1942) but four in condition to operate, all under one ownership and securing shale from the one pit described above.

The pit in the Juniper Hill member from which the Northwestern States Portland Cement Co. secures its argillaceous material (T) is located in sec. 5, Lime Creek Township, in the western part of Mason City, and north of the pit of the Mason City Brick and Tile Co. The shale was formerly removed by harrowing and dragging,

\footnotetext{
120rally by Mr. Howard Lewis, Ceramic Engineer, Mason City Brick and Tile Co.
} 
and the surface thus exposed was one of plastic silty clay, very light gray on the surface where it had been allowed to dry, but blue gray beneath. It contained abundant gypsum crystals, found lying on the surface. The floor of the present pit, lying approximately 20 feet below the original surface, is of similar material. The working face, from which material is at present (1942) being removed by shovel operations, is made up of 5 feet of gray-buff silty shale overlain by 3 feet of gray silty shale. The difference in color may be due to the water-soaked condition of the lower part, since it probably has been covered with water when the pumps were not working and the pit was flooded.

Analyses of shale from this pit have been furnished by the Northwestern States Portland Cement Co. and are included in the section discussing chemical analyses of Iowa shales and clays.

The shale from the Juniper Hill member is also used by the Lehigh Portland Cement Co. located in the northern part of Mason City. The pit is west of the plant in sec. 32; Lime Creek Township, and the material exposed is much like that described in the foregoing.

These two companies have removed great quantities of shale from extensive acreages in the course of their operations. This may be judged from the fact that the annual capacity of the Northwestern States Portland Cement Co. is $2,000,000^{\circ}$ barrels of cement and that of the Lehigh Portland Cement Co. is $1,750,000 ; 25$ percent shale is used in the raw material or approximately 140 pounds per barrel of cement.

Shale from the Juniper Hill member is also used in the manufacture of heavy clay products by the Rockford Brick and Tile Co. The plant and pit are located southwest of Rockford, Floyd County, on the south side of the valley of Clay Bank Creek in the NE1/4 sec. 16, Rockford Township. (Fig. 1).

Section: Rockford Brick and Tile Co., Rockford, Floyd County.

\begin{tabular}{|c|c|c|}
\hline & Donorintion or & Thickne \\
\hline$\underset{4}{\text { Member }}$ & $\begin{array}{l}\text { Description } \\
\text { Till, intermingled with weathered shaly limestone be- } \\
\text { low, yellow and buff in color, very fossiliferous in }\end{array}$ & \\
\hline 3 & $\begin{array}{l}\text { places, constitutes overburden. } \\
\text { Shale, blue gray, plastic when wet, silty }\end{array}$ & $\operatorname{upp}_{5-8}$ to 15 \\
\hline 2 & $\begin{array}{l}\text { Sandstone, fine-grained, or siltstone, slightly calcare- } \\
\text { ous, poorly cemented, stained irregularly brown with } \\
\text { limonite where overlying material is thin and water }\end{array}$ & \\
\hline 1 & $\begin{array}{l}\text { permeates, forms waste, at least where well-cemented. } \\
\text { Shale, blue gray, plastic when wet, silty, with some } \\
\text { horizons a foot or more thick containing larger amount }\end{array}$ & $1-2$ \\
\hline & & 25 \\
\hline
\end{tabular}




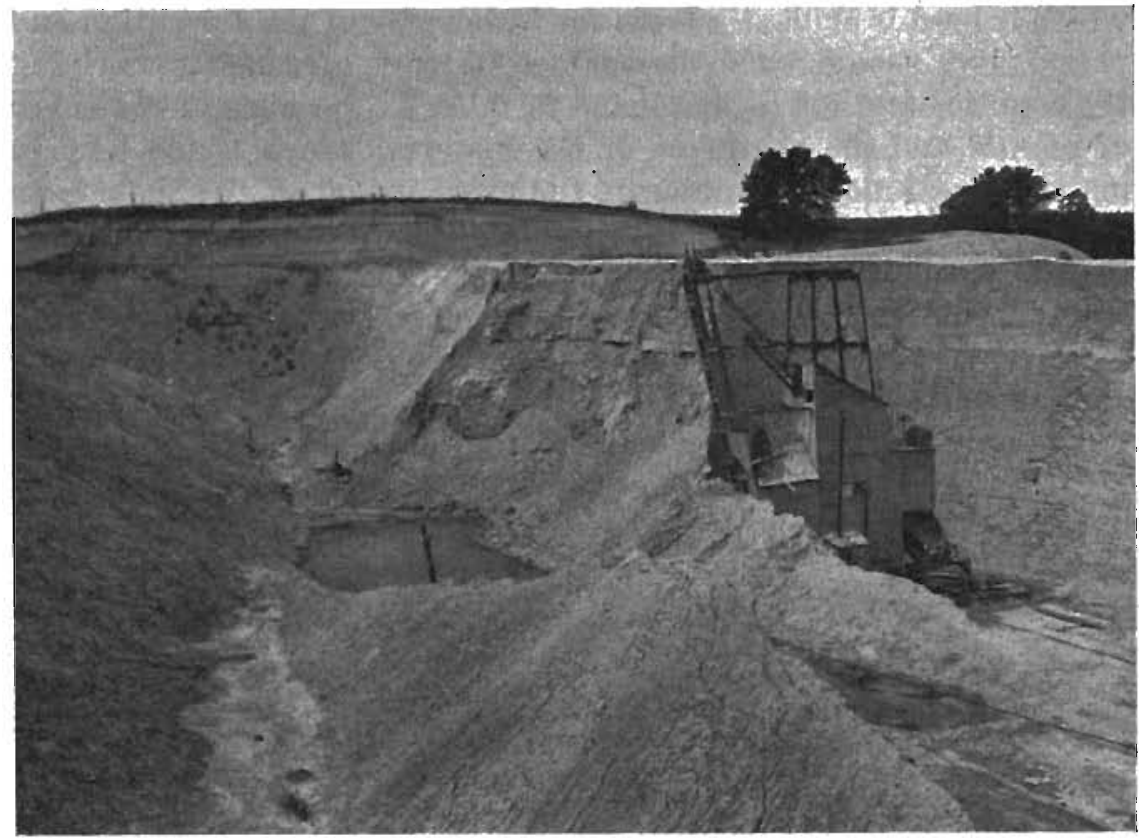

Figure 1. Shale pit, of the Rockford Brick and Tile Company, Rockford, Floyd County.

The highly fossiliferous weathered limestone which forms much of the overburden is believed to be the base of the overlying Cerro Gordo member of the Lime Creek formation. The bulk of the material in this section is much like that of the sections exposed at Mason City. It has here, as there, the advantage from the viewpoint of the heavy clay products manufacturer of being rather uniform in composition. The content of calcite is apparently not great enough to be a detriment.

The Sheffield formation. The Sheffield is believed to form the surface bedrock of a belt extending from western Johnson County northwest through Iowa, Benton, Tama, Grundy, Butler, Franklin and Cerro Gordo to southeastern Hancock County. Stainbrook describes the formation as "predominately shale, soft, blue to gray in color, sparsely fossiliferous in the lower part, with thin intercalated layers of brown dolomite. The upper portion is mostly dolomite, brownish in color, more or less massively bedded with subordinate green and brown shales and thinly bedded gray limestone."

Shale from this formation is used by the Sheffield Brick and Tile Co., Sheffield, in the manufacture of heavy clay products. That 
which is used is evidently from the lower part of the formation and presumably should form the surface bedrock of a belt underlying the counties and townships listed in table 3. Because of the cover of mantle and the character of the material which would tend to make it break down in outcrop, the exact extent of the shale beds is not known. It should be recognized also that the character of the material may differ along the strike of the beds, so that the horizon occupied by satisfactory shale at Hampton may contain a more limy shale or shaly limestone at points some distance away along the strike of the formation.

The only company using shale of the Sheffield formation is the Sheffield Brick and Tile Co., located south of Sheffield, Franklin

TABLE 3

Approximate Distribution of the Sheffield Formation by Counties and Townships

Hancock County

Sections 8, 9, 10,11, 12, 16, 17, 18, of Avery.

Cerro Gordo County

Middle third, trending southeast of Grimes.

Southern third of Pleasant Valley.

Southern quarter of Geneseo.

Franklin County

Southern fifth of Dougherty.

Northeastern corner of Ross.

Northeastern two-thirds of Westfork.

Eastern quarter of Ingharn.

Butler County

Western quarter of Bennézette.

Western third of Pittsford.

One-third of Madison; a strip trending southeast from the northwest corner.

Southwestern third of Ripley.

Northeastern half of Monroe.

Grundy County

Southwestern third of Albion.

Beaver, exclusive of northeastern and southwestern corners.

Eastern two-thirds of Lincoln.

Southwestern third of Grant.

Northwestern quarter of Washnigton.

Tama County

Black Hawk, with the exception of the Northeastern quarter.

Northeastern half of Grant.

Southwestern two-thirds of Buckingham.

Northeastern half of Perry.

Clark, with the exception of the northeastern quarter.

Benton County

Southwestern quarter of Monroe.

Western half of Homer.

Kane, approximately half, from northwest to southeast.

Northeastern fifth of Iowa.

Southwestern fifth of Union.

Southwestern two-thirds of Leroy.

Southwestern sixth of St. Clair. 
Iowa Gounty

Northeastern quarter of Marengo.

Northern half, exclusive of northeast corner, of Washington.

Southern half of Lenox.

Johnson County

Northeastern quarter of Iowa.

Small area, southwestern corner of Monroe.

Northwestern quarter of Oxford,

County, on the south side of the valley of Bailey Creek in the NW1/4 sec. 9, Ross Township (T. 93 N., R. 20 W.). The shale pit is north of the plant; it has been extended west to the point where the thick drift overburden is becoming a problem.

Section: Sheffield Brick and Tile Co., Sheffield, Franklin County.

\begin{tabular}{|c|c|c|c|}
\hline Member & Description & $\begin{array}{l}\text { Thic } \\
\text { Fee }\end{array}$ & $\begin{array}{l}\text { mess } \\
\text { Inches }\end{array}$ \\
\hline 4 & Drift, chiefly till, weathered, a few feet of & & \\
\hline 3 & $\begin{array}{l}\text { top soil } \\
\text { Shale, blue gray to brown where stained with limon-.. } \\
\text { ite, silty, somewhat calcareous, contains slightly cal- } \\
\text { careous fine-grained sandstone or siltstone, brown } \\
\text { with weathering on joint faces at least, up to } 4 \text { inches }\end{array}$ & 3 & 10 \\
\hline 2 & $\begin{array}{l}\text { thick } \\
\text { Sandstone, fine-grained, or siltstone, hard, noncal- }\end{array}$ & 10 & 11 \\
\hline 1 & $\begin{array}{l}\text { careous, weathers buff, joint surfaces dark brown..... } \\
\text { Shale, dark gray where wet, but dries to light gray, } \\
\text { silty, plastic. (T) }\end{array}$ & 23 & 4 \\
\hline
\end{tabular}

Only member 1 is used as raw material. The number of siltstone beds has increased as the pit has been extented west. This is due to the section getting higher.

Summary. From the foregoing, it is apparent that the shales of the Sheffield formation and of the Juniper Hill member of the Lime Creek formation as used by the ceramic plants at Mason City, Rockford and Sheffield and by the cement plants at Mason City, are much alike. In each case the material is a gray-blue, silty shale, in places somewhat calcareous unless leached by weathering.

Horizons or beds of more sandy or silty material are also present in these sections and some of them are cemented with more calcite.

The shale from any one of these pits is quite uniform, which should be an asset in its use. Those of the Des Moines series, the next to be considered, may show considerable variation, at least in color, in a single pit. The ceramic ware made from these Devonian shales is obviously a satisfactory product. -The tests made upon them confirm their suitability for the manufacture of heavy clay products, but do not suggest possibility of their use in higher grade products such as pottery or refractory ware. 


\section{SHALES AND CLAYS OF THE DES ḾOINES SERIES}

Introduction. The shales and clays of the Des Moines series constitute a raw material resource of great value. They form the surface bedrock of an area of many thousand square miles and are accessible at many places.' Some of the largest heavy clay products plants of the State secure their raw material from this series.

Extent. The series forms the top of the bedrock over a large area, extending as a broad curving band (pl. 2) northwestward from Pottawattamie and Harrison to southern Humboldt County, and thence southeastward to the southern boundary of the State in Wayne, Appanoose, Davis and Van Buren Counties. It covers all or practically all of Dallas, Polk, Lucas, Jasper, Monroe, Wayne, and Appanoose; more than approximately half of Harrison, Shelby, Carroll, Crawford, Sac, Calhoun, Hardin, Story, Boone, Greene, Webster, Warren, Marion, Mahaska, Wapello, Jefferson and Van Buren; and less than approximately half of Pottawattamie, Wright, Audubon, Pocahontas, Humboldt, Franklin, Grundy, Guthrie, Poweshiek, Madison and Keokuk Counties. From the presence of scattered outliers northeast of the main belt in Lee, Des Moines, Henry, Louisa, Washington," Johnson, Muscatine, Clinton, Scott and Jackson Counties, it is known that this series at one time extended far to the east of its present boundaries, and was continuous with the Pennsylvanian formations of Illinois.

Structure and relations. The direction of dip of the beds of the series varies, depending upon the position of the locality with respect to the periphery of the structural basin of which they are a part. They dip approximately south in the northern part, southwest and west on the east side, and southeast and east on the west side. The axis of the basin trends approximately $\mathrm{S}$. $25 \mathrm{~W}$. from the vicinity of Fort Dodge. Dips are generally low, of the order of 10 feet per mile. There frequently are reversals of these regional. dips. Faults of small magnitude are also present.

In the central part of the basin, away from the area of outcrop, the Des Moines is covered by the Missouri series of the Pennsylvanian system, by Cretaceous beds, or both. The thickness of surface materials, glacial drift', loess, alluvium, and residual mantle ranges up to a few hundred feet; and varies greatly from place to place. Some counties have very few or no outcrops and in others they are abundant.

Thickness and stratigraphy. The Des Moines series has a maxi- 


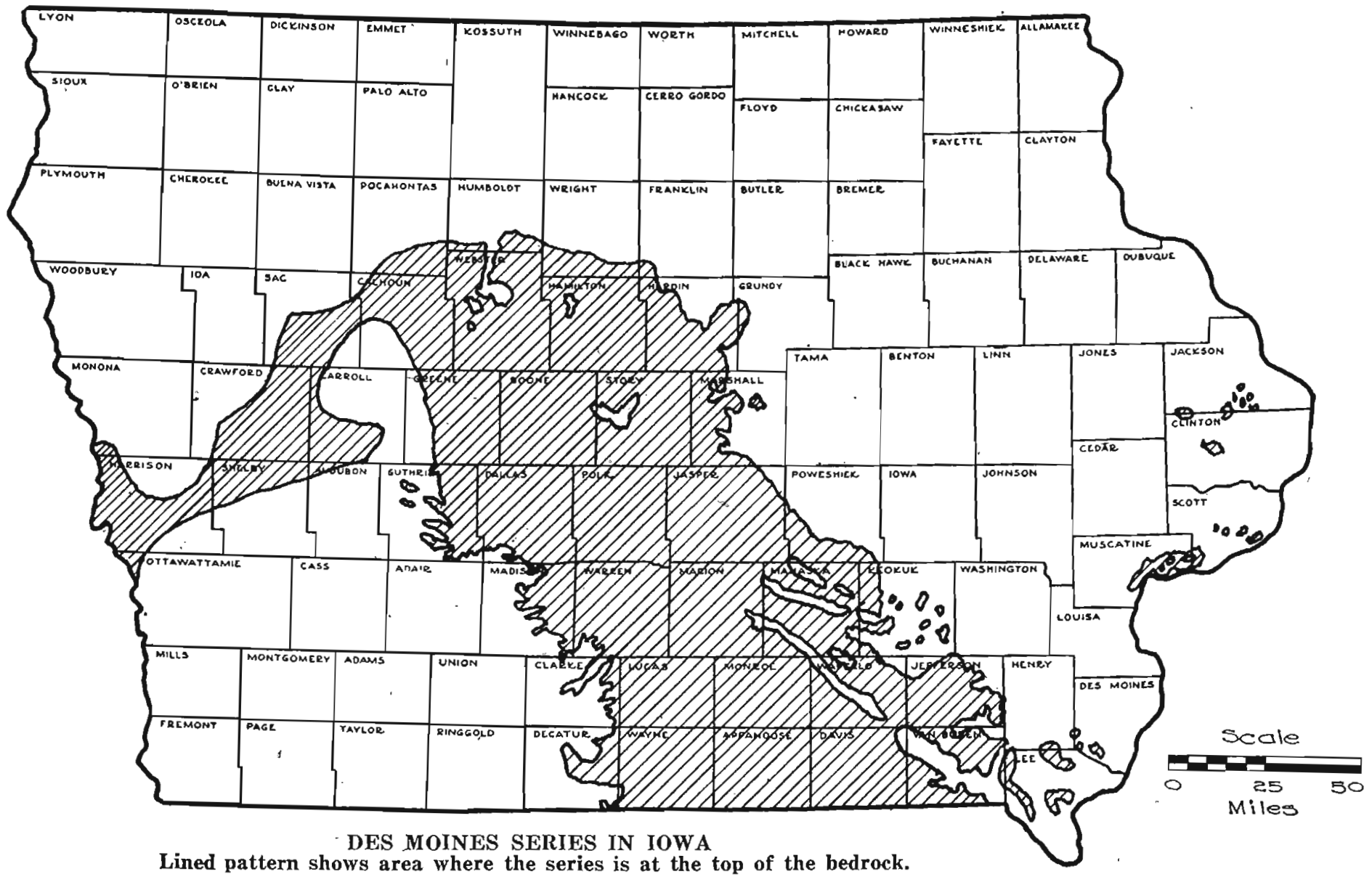




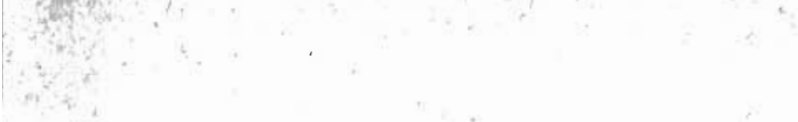

5

,

.

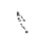


mum thickness of approximately 750 feet, a large proportion of which is shale, with lesser amounts of clay or underclay, sandstone, limestone, conglomerate and coal. Most of the shale is silty, some of it so much so that it might more properly be called siltstone. Such material will however be called shale in this report, since it is generally not discriminated as siltstone by ceramic manufacturers. Some of the shales are sandy, some calcareous or limy and others carbonaceous. Calcareous and carbonaceous shales are less desirable for ceramic purposes than the shales in which they are lacking.

Beds of these different kinds of shale occur interstratified with other rocks and in the upper part of the series the same succession is repeated many times. Such a succession of beds, called a cyclothem, has sandstone at its base and, in order above, silty shale or siltstone, underclay, coal, carbonaceous shale, silty shale, limestone and silty shale. An individual cyclothem may have a thickness of scores of feet.

The individual beds of the series vary greatly in thickness. In places, as at the Ledges State Park, beds of sandstone are approximately 100 feet thick, but this is extreme. Some of the beds are sharply set off from one another; others grade vertically or laterally from one kind of rock to another. Some of the beds have only limited areal extent and others extend over large areas.

Shale. Mast of the shale members of the Des Moines series are some shade of gray in color, many others are maroon and there are others that are various shades of red, brown and yellow. Many of the beds are not of a solid color, but are banded, streaked or mottled. The various shades of red, brown and yellow are due to the presence of iron oxide minerals, usually hydrated, where the iron is in the ferric state; although the iron content of these shales may be no higher than that of the gray shales. These oxidized and hydrated iron-containing minerals may be original, or they may be secondary, formed as a result of the action of oxidizing ground waters upon the shales subsequent to their deposition. A similar change of color upon oxidation is quite apparent in the glacial clays of the mantle; deep road and stream cuts grade from a blue gray, the original color of the glacial clay, upward to some shade of brown at the top.

Calcareous or limy shales, less common in the Des Moines series, have a content of the mineral calcite. The calcite may have been originally present in the sediment, or it may have been brought in by ground water and precipitated. In some places calcareous and ferruginous or iron-containing nodules of various shapes are formed 
in the shale by this precipitating action of ground water. Such masses known as concretions are obviously undesirable in commèrcial shale since they are difficult to crush fine, and the particles burn to free lime.

The carbonaceous shales contain carbonized remains of plants which accumulated with the mud or clay. Accumulation of plant material alone leads to the formation of peat and subsequently coal. A carbonaceous shale will often be found to grade laterally into coal or to lie above it.

Underclay. Coal and coal horizons are usually underlain by clay of variable thickness known as underclay. This clay usually is more refractory than the shale of the series and ranks as fire clay. Fire clay of the best quality is not believed present in any quantity in the Des Moines series in lowa. In many parts of the United States, particularly in the coal fields east of Iowa, the clays beneath the coal are notably more refractory than the great body of shales of the series. They burn only at high temperatures, and the products made from them will resist a high degree of heat, and so can be used in furnace linings and crucibles. The products are also generally white or light buff in color. The unusual character of these fire clays is largely due to the lack or low content of fluxing and coloring oxides such as those of potassium, sodium, magnesium, calcium and iron. These constituents are believed to have been removed from the clays during the growth of the coal-making plants above them. Fire clays in commercial thicknesses, suitable for use in refractories, have not yet been found in Iowa. Most of the underclays of Iowa contain finely divided pyrite which produces brown or "iron" spots of low melting point in the product. Some of them, however, have proven suitable for the manufacture of buff brick, but the deposits are not very thick.

Overburden and outcrops. The thickness of the mantle directly overlying the Des Moines series ranges, as it does over the bedrock of the entire State, to as much as a few hundred feet. It is thickest in the area of the Mankato or youngest drift, which extends from the city of Des Moines north to the northern boundary of the State, where it has a width of several counties. Many of the counties in this area have no outcrops of the consolidated rock beds, others have but few where the mantle is thin. Outcrops and places of thin mantle are along the sides of steep, sharply incised valleys.

Outside of the area of Mankato drift the overlying mantle is on the whole thinner, but even here there are large areas without out- 
crops of indurated materials. Areas with valley systems well developed may have numerous outcrops along the sides of the valleys.

Because so much of the Des Moines series is shale, outcrops and man-made exposures are likely to become covered relatively quickly by slope wash and vegetation, since the shale softens so easily upon weathering. The outcrops are therefore lacking unless steepened and renewed by stream cutting. The limestone and sandstone beds interstratified with the shales are somewhat more resistant to weathering and erosion, and may persist in outcrop. Their presence may thus serve as a guide to overlying or underlying shales or clays which are covered by mantle. Localities having the thick channel sandstones are, however, to be avoided, since they cut irregularly into the shales and attain a thickness of scores of feet.

Bedrock shale and clay pits are comomnly located on the sides of valleys not only in the Des Moines series, but elsewhere. There the mantle is thinnest, therefore the cost of extracting the clay is less because of the smaller amount of overburden to be moved. As the pit is extended into the side of the valley, the thickness of mantle mounts rapidly if the valley is steep-sided, and experience has shown that much difficulty may be experienced if the mantle is waste material, particularly glacial clay, that must be removed.

It is also a matter of common observation that the shale near the surface on the side of a valley has been considerably affected by weathering. It has been softened, leached and somewhat oxidized. As the pit is extended into the valley side, and the distance from the surface becomes greater, the shale is less affected by weathering. The ceramic character of a particular horizon thus changes as the pit is extended, a matter which may lead to difficulty in the treatment of the material unless it is well understood.

The distribution of the Des Moines series in the counties where it occurs, its characteristics, the extent to which it is used and related matters are described in the following pages. County reports of the Iowa Geological Survey dealing with the geology of the respective counties will be cited in cases where they contain information on the series.

Appanoose. ${ }^{13}$ The beds of the Des Moines series form the top of the bedrock throughout Appanoose County. The mantle ranges up to 150 feet beneath the divide areas but is thin or absent in many places along the deeper and larger valleys, as along Chariton River, Walnut Creek, Buck Creek, Shoal Creek, Cooper Creek and their

\footnotetext{
19Bain, H. F., Geology of Appanoose County: Iowa Geol. Survey, vol. 5, pp. 374-897, 1896.
} 
larger tributaries. The character of the beds making up the upper part of the series in the county is well known from natural and artificial outcrops, coal mining records and operations, and the shale pit of the Centerville Clay Products Company. Extensive mining of the well-known Mystic coal has contributed much information regarding the stratigraphy of the series. In addition to the coal, the series contains much shale and underclay, thick and persistent limestone members, and conglomerate.

The shales and clays have been used in the manufacture of heavy clay products at Centerville for approximately 40 years, but so far as is known have not been used elsewhere in the county. The plant of the Centerville Clay Products Company is located on the north side of a small tributary of Manson Creek immediately south of Centerville in the $\mathrm{NW1} / 4$ sec. 1 , Vermillion Township, (T. $68 \mathrm{~N}$., R. 18 W.). Shale has been secured from an opening in the valley side east of the plant and the present operation is in the south end of this pit.

Section: Centerville Clay Products Company; Centerville; Appanoose County.

\begin{tabular}{|c|c|c|c|}
\hline Member & Description & $\begin{array}{l}\text { Thic } \\
\text { Feet }\end{array}$ & less \\
\hline 6 & 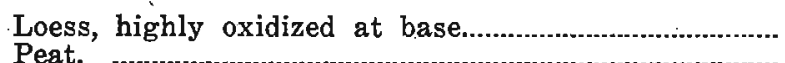 & $\cdot 7$ & 6 \\
\hline 4 & $\begin{array}{l}\text { Shale, dull yellow-brown, slightly silty, lacks definite } \\
\text { stratification, probably a weathered phase of under- } \\
\text { lying material, contains clay ironstone concretions } \\
\text { up to } 3 \text { feet in diameter. }\end{array}$ & 20 & \\
\hline 3 & 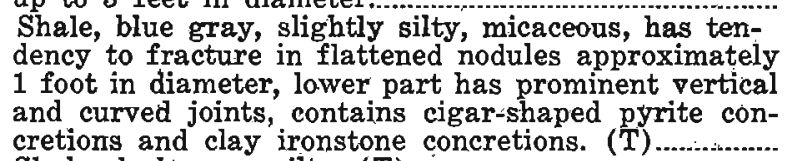 & 26 & \\
\hline $\begin{array}{l}2 \\
1\end{array}$ & $\begin{array}{l}\text { Shale, dark gray, silty. (T) } \\
\text { Limestone }\end{array}$ & 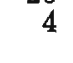 & 8 \\
\hline
\end{tabular}

In older parts of the pit carbonaceous shale and fossiliferous limestone lie above member 4 of the above section.

The section is notable among those in shale pits of the Des Moines series in that it is essentially uniform for the entire thickness of $\mathbf{5 0}$ feet, except for a slight variation in amount of silt and the weathering of the upper part of the section; uniformity of color of the unweathered shale is conspicuous. The entire section, exclusive of 6 inches of topsoil and the clay ironstone, concretions, has been used in the manufacturing process, and suitability of the materials thus made apparent. Variation in the behavior of the material from the various members has been observed, members 3 and 6 being considered notably plastic and member 4 rather short. 
Audubon. Boundaries of the area directly underlain by the Des Moines series in Audubon County are not accurately known. The beds are believed to form the top of the bedrock of an area of many square miles in the northwestern part, in northern Lincoln and northwestern Cameron Township. Elsewhere they are overlain by younger sedimentary rocks. They are not exposed in the area where they form the top of the bedrock because of the thick drift mantle and the lack of deep valleys.

Thickness of the series in this area is presumably not more than a few score feet. Shale and clay are undoubtedly present as in other counties where the series is present but they are hardly of even potential value, because of the generally thick overburden.

Boone. ${ }^{14}$ Beds of the Des Moines series form the surface bedrock of the entire county except for an area of 1 or 2 square miles in eastern Jackson Township. They are exposed or covered with only thin mantle in many places along the Des Moines River and to some extent along the lower parts only of its deeper tributaries. Elsewhere they lie beneath drift that may average more than 100 feet in thickness. Much information regarding them has been gained from coal borings and shafts.

Shales and clays suitable for the manufacture of ceramic products are believed numerous in the section; coal, limestone and sandstone are other constituents. A channel sandstone up to 80 feet thick forms the top of the section along the Des Moines River in: Worth and Clay Townships. Shales and clays from the series were used in a plant at Logansport as recently as 1927 . The pit located west of the plant on the east side of the valley of Des Moines River in the NE1/4 sec. 24, Des Moines Township (T. 84 N., R. 27 W.) eventually encountered excessive overburden. Beyer has described the following section from this locality:

\begin{tabular}{|c|c|c|}
\hline Member & Description & $\begin{array}{l}\text { Thickness } \\
\text { Feet Inche }\end{array}$ \\
\hline 8 & $\begin{array}{l}\text { Drift and talus, varying in thickness, average for } \\
\text { pit at the present time. (1903)........... }\end{array}$ & $\mathbf{5}$ \\
\hline 7 & $\begin{array}{l}\text { Shale, variegated, gypseous, mueh weathered and } \\
\text { shrinks considerably during drying and burning. }\end{array}$ & 15 \\
\hline 6 & $\begin{array}{l}\text { Shale, gray blue, arenaceous below, in places a hard } \\
\text { ledge appears and must be wasted. }\end{array}$ & 4 \\
\hline $\begin{array}{l}5 \\
4\end{array}$ & $\begin{array}{l}\text { Shale, purplish, variegated, osomewhat fissile. } \\
\text { Sandstone, argillaceous in part, hard ledge appears } \\
\text { in places.......................... }\end{array}$ & 4 \\
\hline 3 & $\begin{array}{l}\text { Shale, dense, gray blue to deep blue, but slightly fis- } \\
\text { sile, the most important bed in the pit... }\end{array}$ & 14 \\
\hline 2 & 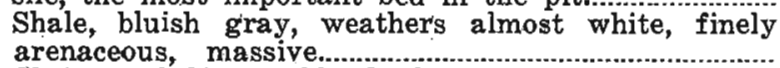 & 4 \\
\hline 1 & Shale, dark blue to bluish black, gypseous. & \\
\hline
\end{tabular}


Calhoun. The Des Moines series is thought to underlie all of Calhoun County with the exception of the northwestern half of Williams Township. It is at the top of the bedrock beneath this area with the exception of that part overlain by younger sedimentary rocks; this includes townships as follows:

All of Jackson and Calhoun.

All except the northern fifth of Elm Grove.

The southwestern third of Twin Lakes.

The western third of Union.

Presumably it contains ceramic shales and clays similar to those in adjacent Webster County. They are believed to be without potential value because of the general thickness of overlying mantle and the absence of deep valleys on the sides of which the mantle might be thin.

Carroll. The Des Moines series is believed to underlie the entire county and to form the top of the bedrock throughout except in southwestern and western townships where it is overlain by Cretaceous beds, the boundaries of which are not certainly known. There are no outcrops and little is known of the series from well records, but it almost certainly contains ceramic shales and clays as it does in nearby Boone, Webster and Dallas Counties. These are also believed to lack potential value as a resource because of the generally thick mantle of glacial drift and the absence of deep valleys.

Clinton. Relatively small outliers or parts of outliers of the Des Moines series, none more than a few square miles in extent, in southwestern Welton. northern Bloomfield, and northern Sharon Townships, consist principally of sandstone. Shale and underclay are also present, but not believed to be thick enough to constitute a potential clay resource.

Crawford. Beds of the Des Moines series form the top of the bedrock beneath all of Crawford County with the exception of the northwestern townships. Boundaries are not definitely known. The beds are everywhere beneath drift averaging 100 feet or more in thickness, and while ceramic shales and clays are presumably present as in other counties, they have no potential value because of the heavy drift cover.

Dallas. Beds of the Des Moines series form the surface bedrock beneath the entire county with the exception of small areas in the southwestern corner, including the approximate south half of Union and the southwest quarter of Adams Townships. The mantle cover is thin and outcrops present in many places along the deeper valleys, 
the Des Moines River in Des Moines Township, the Middle Raccoon River in Linn and Union, the South Raccoon in Union, Adams, Van Meter and Boone Townships, and the lower parts of some of the deeper tributaries to these streams. The character of the beds is known from these outcrops, from the exposures at the shale pits at Adel and Redfield and from coal mining records and operations. Shale and clay are notably abundant in the upper part of the series as represented in the county, although there are also coals and thin limestones, as well as thick sandstones in some places, as along the west side of the Raccoon River at Redfield. Underclays which have the quality of a low grade fire clay are as elsewhere associated with the coal horizons.

The shales and clays have been used in the manufacture of heavy clay products at Adel, Redfield, Van Meter and De Soto. Three plants are at present operating, one at Redfield, one approximately a mile east, and one at Adel.

The sections at these shale pits are believed characteristic of the upper part of the series as it is represented in the southern part of the county. That of the Goodwin Brick and Tile Company (fig. 2) on the east side of the Middle Raccoon River Valley immediately

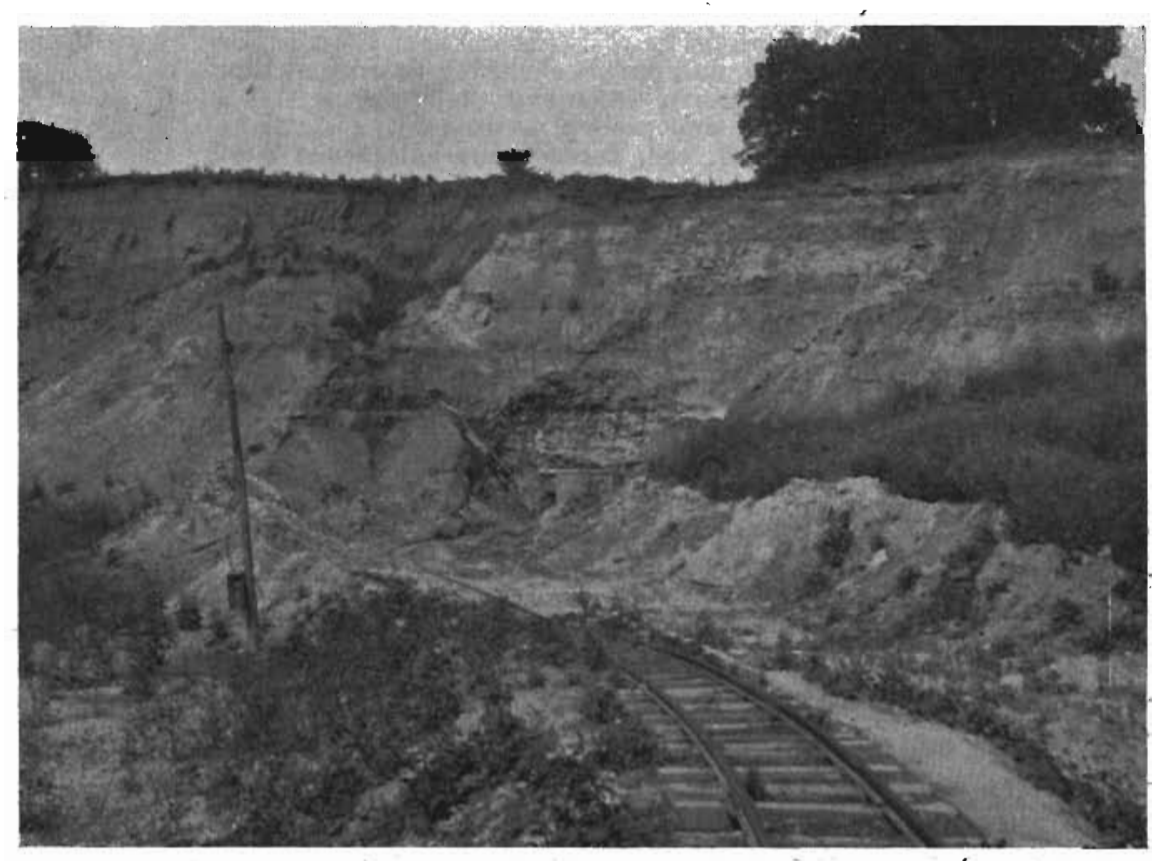

Figure 2. Shale pit of the Grodwin Brick and Tile Company, Redfield, Dallas County. 
west of Redfield in the NW1/4 sec. 5, Union Township, (T. 78 N., R. 29 W.), is the thickest.

Section: Goodwin Brick and Tile Company, Redfield, Dallas County.

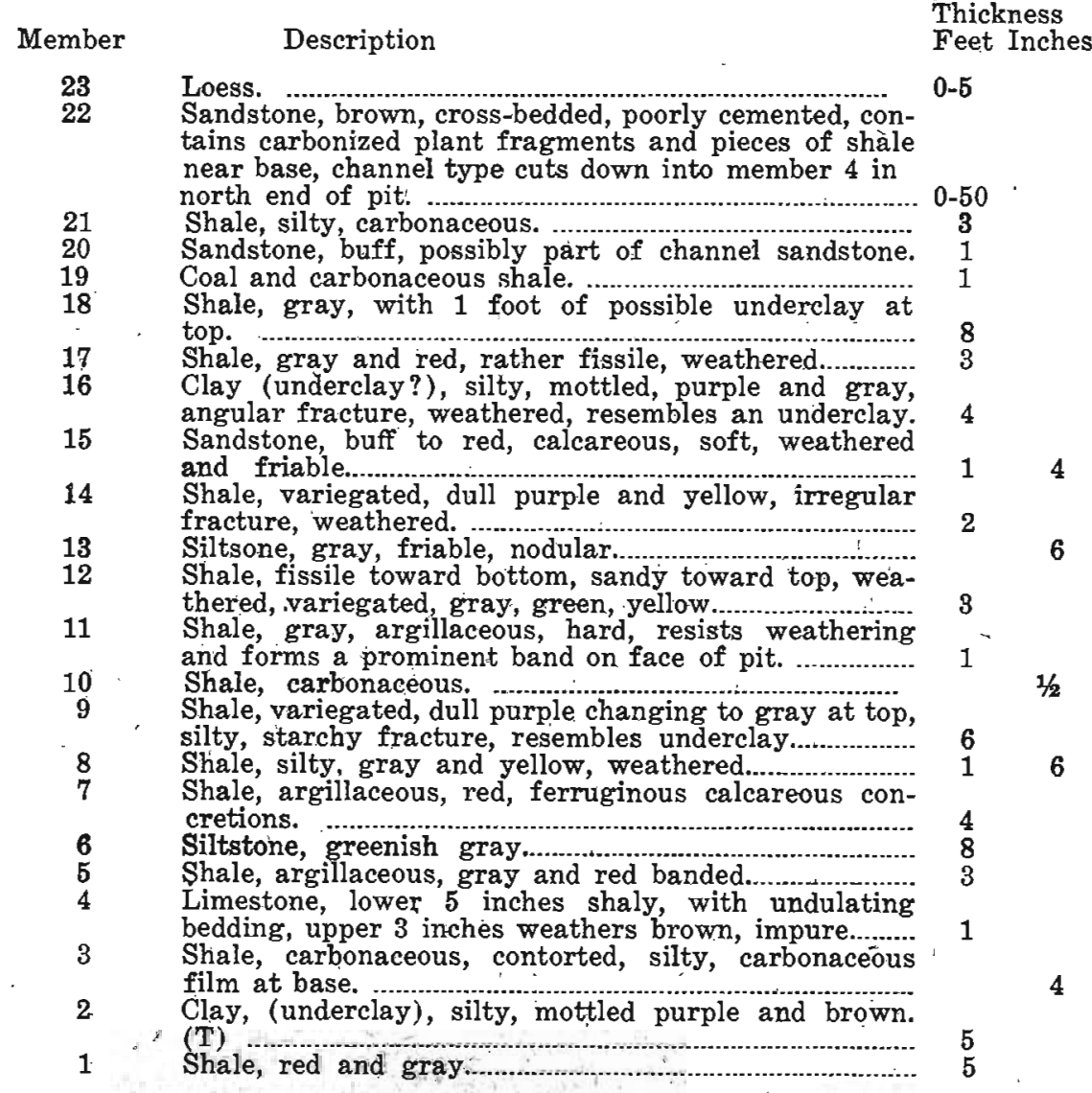

Members 14 to 21 inclusive as exposed in 1942, were all more or less affected by oxidation and solution, causing them to be stained and softened to a varying degree. The material was being taken from the south end of the pit (fig. 3) where the channel sandstone (member 22) was absent, and the entire thickness described above, with the exception of member 4 and calcareous concretions of member 7, was being used. A uniform mix, changing in its ceramic properties only very slowly and over a long period of time, was being obtained by the use of a planer. The relations in this pit are unusual due to the presence of the channel sandstone of varying 


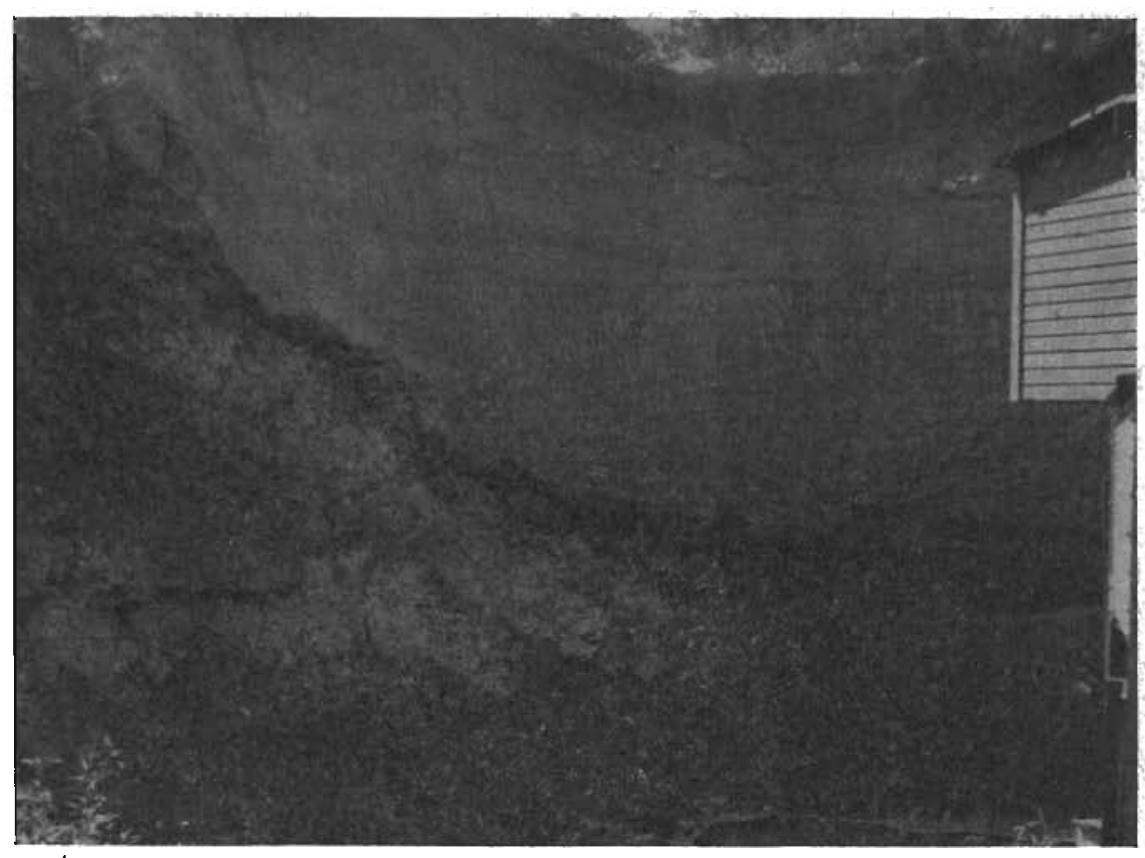

Figure 3. Channel sandstone at the pit of the Goodwin Brick and Tile Company, Redfield, Dallas County.

thickness, (fig. 4) and to the presence of at least one fault which cuts the pit, with downthrow to the north.

The pit of the Adel Clay Products Company. (figs. 5 and 6) is approximately a mile east of that of the Goodwin Brick and Tile Company described above, and three-quarters of a mile east of the village of Redfield. It is also approximately one-half mile north of the plant, on the north side of the valley of Raccoon River in the NW1/4 sec. 3, Union Township, (T. 78 N., R. 29 W.).

\section{Section: Adel Clay Products Company,} Redfield, Dallas County.

\begin{tabular}{|c|c|c|}
\hline Member & Description & $\begin{array}{l}\text { Thickness } \\
\text { Feet Inches }\end{array}$ \\
\hline $\begin{array}{l}8 \\
7 \\
6 \\
5\end{array}$ & $\begin{array}{l}\text { Drift. } \\
\text { Clay (underclay), weathered.................. } \\
\text { Shale, argillaceous, deep maroon throughout............ } \\
\text { Shale, silty, laminated red and gray, a pronounced }\end{array}$ & $\begin{array}{c}1-15 \\
2 \\
4\end{array}$ \\
\hline 4 & $\begin{array}{l}\text { red zone approximately in the middle. (T) } \\
\text { Shale, gray, carboneceous, with member } 3 \text { resists } \\
\text { weathering better than } 2 \text {, and projects from part of }\end{array}$ & $\begin{array}{l}12 \\
\text {, }\end{array}$ \\
\hline 3 & 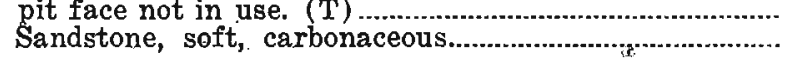 & 2 \\
\hline
\end{tabular}




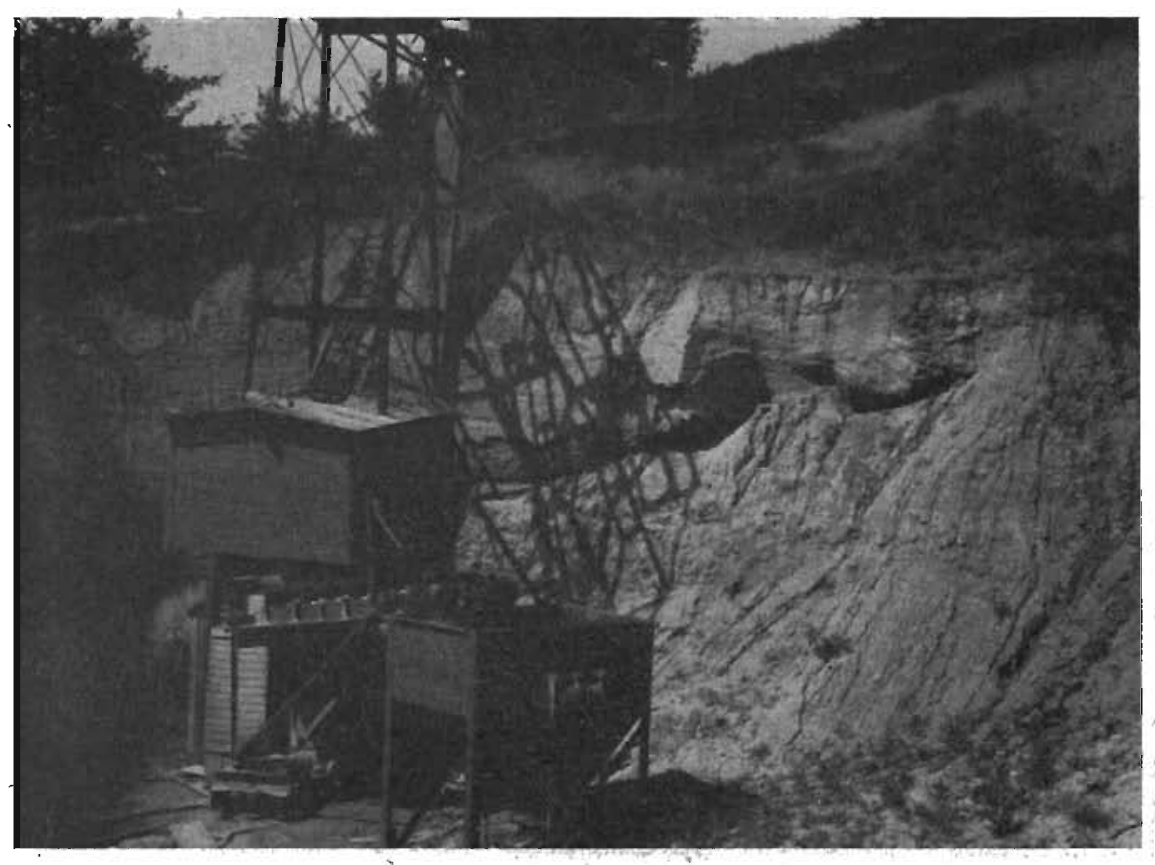

Figure 4. Channel sandstone at the pit of the Goodwin Brick and Tile Company, Redfield, Dallas County. This view is adjacent. to that of fig. 3 .

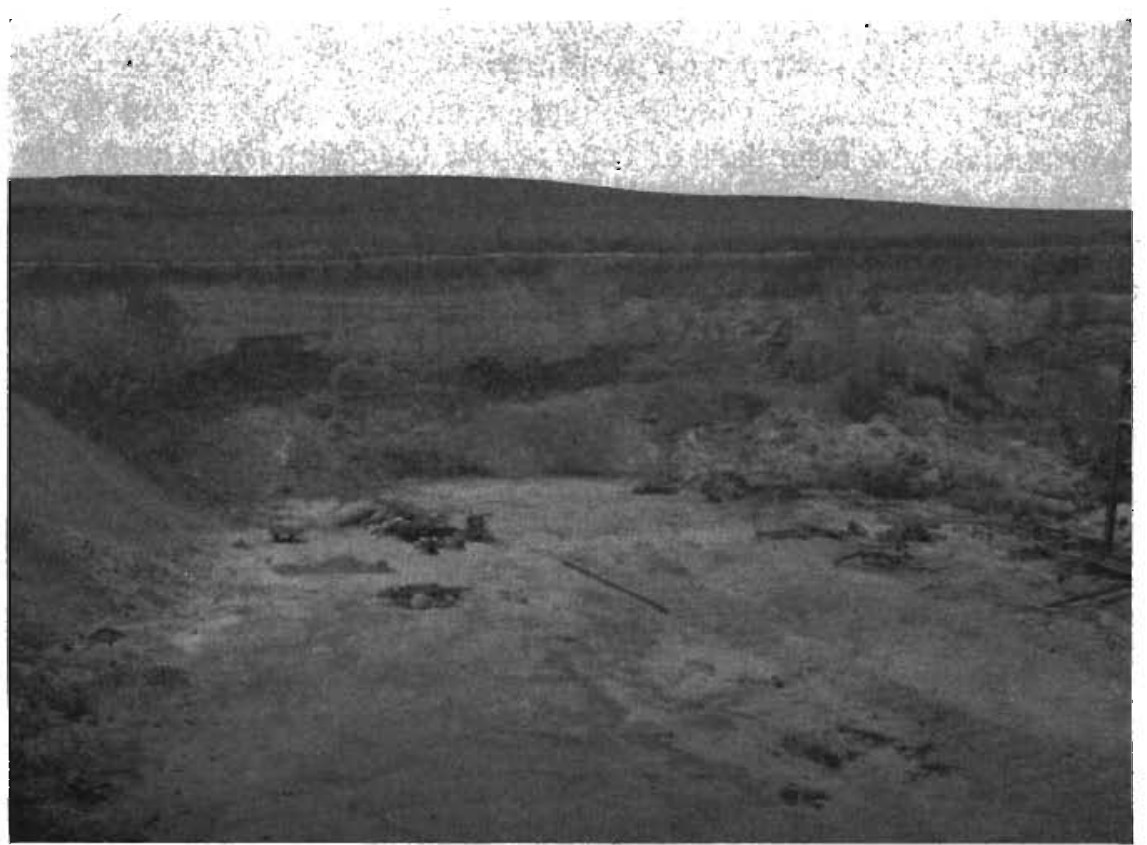

Figure 5. General view north of planer in the shale pit of the Adel Clay Products Company, east of Redfield, Dallas County. 


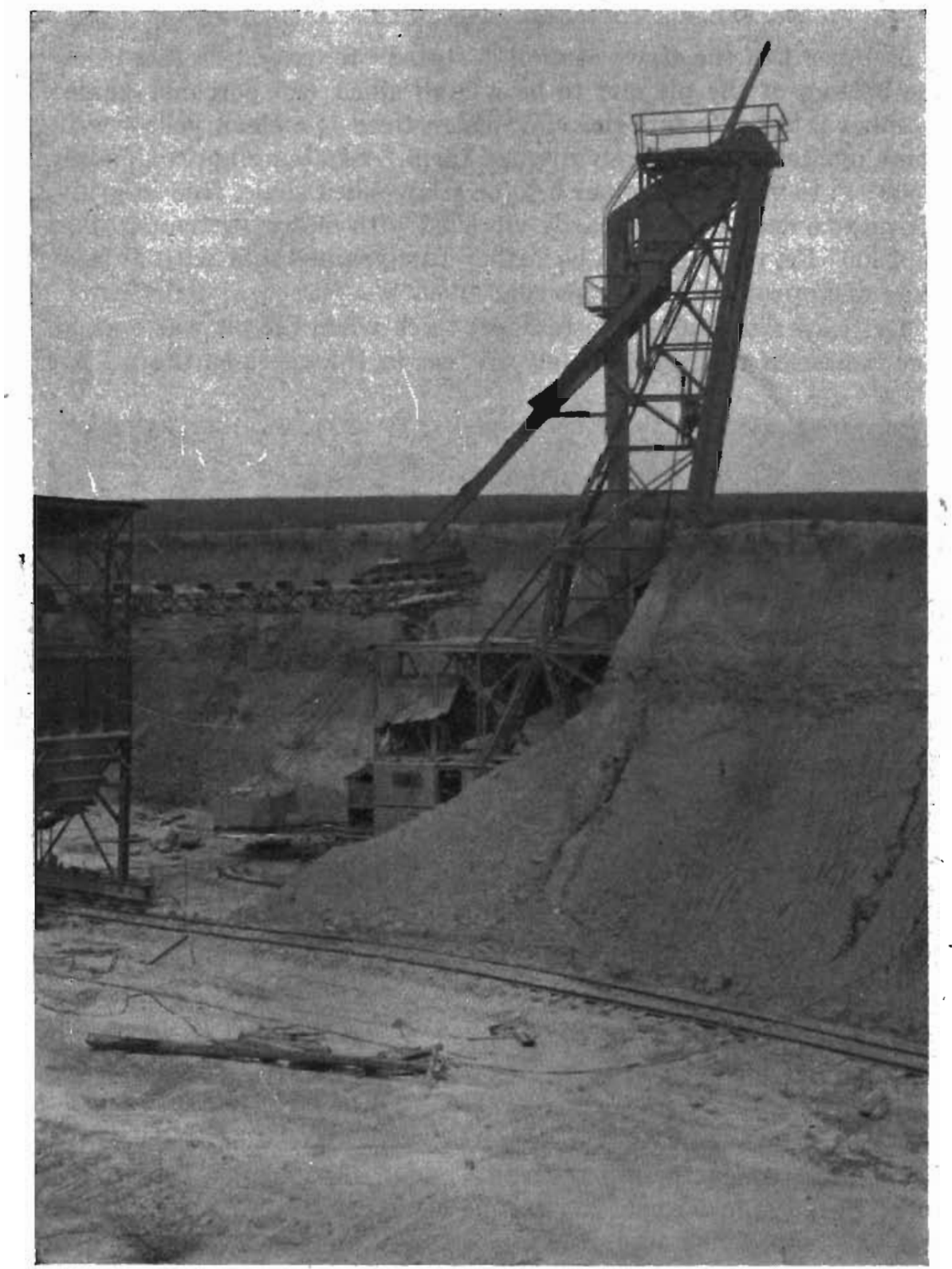

Figure 6. Shale pit of the Adel Ciay Products Company, east of Redfie'd, Da'las County, with planer in position against the shale deposit. 
2 Clay, variegated, purplish, angular fracture, has

1 character of underclay, grades to shale below. (T).... 4

1 Shale, high in silt, greenish gray, splotched with red. (T)

Member 1 of the above section is stated ${ }^{15}$ to extend 28 feet below the bottom of the pit and to be a high silica ( 80 percent) shale; member 2 to be "a fair fire clay which fired is a clean yellow with some pyrites in it in finely divided form," requiring approximately $2400^{\circ} \mathrm{F}$. to vitrify; member 5 to be a low-silica shale, fine in grain, firing to a deep red, and easily vitrified with maturing temperature of $1600^{\circ} \mathrm{F}$. ; member 4 to be rather fine-grained and with an average of approximately 65 percent silica.

Drift overburden, only a few feet thick when the pit was opened, has increased to approximately 15 feet in thickness as the pit has

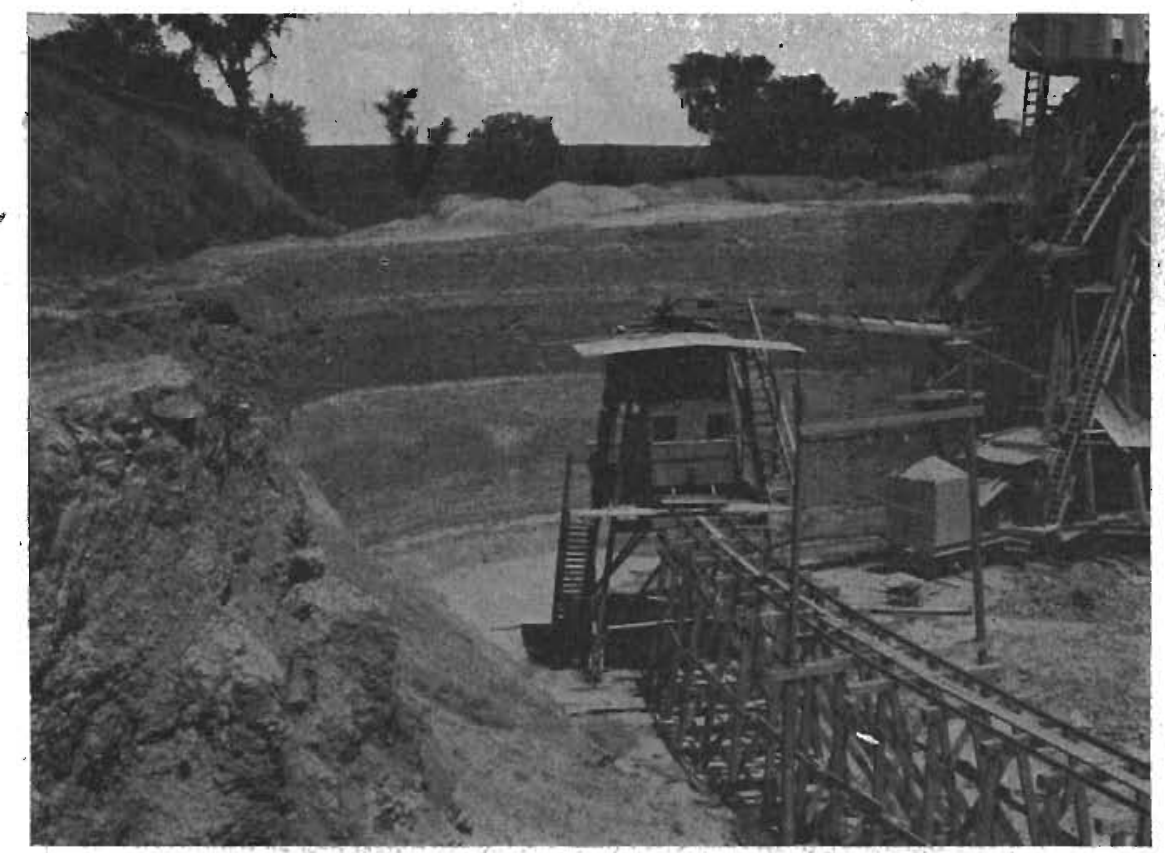

Figure 7. Shale pit of the United Brick and Tile Company. Adel, Dallas County, showing characteristic bedding of the Des Moines series.

been extended north into the valley side. The section is believed to be at the approximate horizon of members 5 to 12 of the pit of the Goodwin Brick and Tile Company. A uniform mix is also at present obtained here through the use of a planer.

\footnotetext{
${ }^{15}$ Correspondence with H. R. Straight.
} 
Material used by the United Brick and Tile Company at its plant in the western limits of Adel is similar to the above. The pit (fig. 7) is approximately one-half mile north of the plant on a small tributary of the North Raccoon River in the SW1/4 NE $1 / 4$ sec. 30, Colfax Township (T. 79 N., R. 27 W.).

Section: United Brick and Tile Company, Adel, Dallas County.

\begin{tabular}{|c|c|c|}
\hline Member & Description & $\begin{array}{l}\text { Thickn } \\
\text { Feet I }\end{array}$ \\
\hline 8 & $\begin{array}{l}\text { Glacial drift, including } 10 \text { feet of rusty sand and } \\
\text { gravel, underlain and overlain by till... }\end{array}$ & $15-20$ \\
\hline 7 & $\begin{array}{l}\text { Shale, red, with gray in middle, argillaceous and only } \\
\text { slightly silty, fissile when dry. }\end{array}$ & $10-20$ \\
\hline $\begin{array}{l}6 \\
5\end{array}$ & $\begin{array}{l}\text { Siltstone, gray, indurated, slightly calcareous.............. } \\
\text { Shale, finely laminated light and dark gray, silty........ }\end{array}$ & \\
\hline $\begin{array}{l}4 \\
3\end{array}$ & $\begin{array}{l}\text { Shale, carbonaceous, sandy } \\
\text { Clay, gray at top, purplish toward bottom, has ap- }\end{array}$ & \\
\hline 2 & pearance of underclay............ & 4 \\
\hline 1 & $\begin{array}{l}\text { red-brown calcareous concretions which are dug out } \\
\text { and rejected, slightly silty. } \\
\text { Shale, gray and red, in thick zones near bottom, }\end{array}$ & 4 \\
\hline & 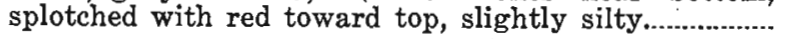 & 12 \\
\hline
\end{tabular}

This section is also believed to be at the approximate horizon of members 5 to 11 of the pit of the Goodwin Brick and Tile Company at Redfield, and a uniform mix is also at present obtained with the use of a planer.

The three sections give a picture of an abundance of shale and clay in this part of the county. The beds furthermore range in character, and constitute a satisfactory raw material when used together. The section in each case is essentially one of shale with a lesser amount of underclay. The shale beds range in the amount of silt and some of them are high enough in silt to be called siltstones. The color varies depending on whether iron compounds have been oxidized, but is of little or no importance from the ceramic standpoint. The total amount of silt and fine sand in the sections varies from one point to another, but with the use of the planer the mix is uniform from day to day, and changes so slowly that there is no difficulty in the operation of the presses and kilns.

Des Moines. The few small optliers of the Des Moines series in northwestern and eastern Augusta, southwestern Danville and western Union Townships total no more than 7 square miles in area. They consist of sandstone, coal, clay and shale known from several outcrops. These outliers contain beds of the more common and less 
refractory shale in some quantity, ${ }^{16}$ but they offer no particular advantage with respect to quantity, location or amount of overburden. Buff-burning semi-refractory clays from the area in Danville Township were at one time used in the manufacture of pottery at Burlington. ${ }^{17}$

Franklin. The beds of the Des Moines series form the surface bedrock of most of Oakland and of the southwestern third of Morgan Townships. They are probably much like those of the series in Webster County to the west but lie beneath such thick mantle that the use of shale and clay from them is in any case not likely.

Greene. All except the western townships are believed directly underlain, beneath the mantle, by beds of the Des Moines series. Presumably quite like those of Boone County to the east. Cretaceous rocks overlie the Des Moines series in the following western townships:

All of Kendrick, Scranton and Willow.

A strip up to 3 miles wide in western Bristol, Jackson and Green Brier. All except the northeastern quarter of Cedar.

Here also drift overburden is thick and there is an absence of deep valleys in which the beds might be exposed or close to the surface. For this reason alone any shales or clays of the series in the county have little or no potential value.

Grundy. Beds of the Des Moines series are believed to form the top of the bedrock of western Shiloh and northwestern Melrose Townships. They are not exposed but presumably resemble those along the Iowa River near Eldora to the west. They are beneath such thick overburden and the area is so lacking in deep valleys in which they might be exposed or near the surface that any shales and clays which might be present are considered to have little or no potential value.

Guthrie. ${ }^{18}$. Beds of the Des Moines series directly underlie the mantle of drift and alluvium in most of the eastern townships and in narrow areas along the valleys of the larger streams in the western part, such as the Raccoon and Middle Raccoon Rivers, including townships as follows:

Richland with the exception of approximately a square mile in the southwest corner.

Cass with the exception of an irregularly shaped strip not more than a mile wide along the west side.

Jackson with the exception of a belt a few miles wide on the divide between the Middle and South Raccoon Rivers.

Penn with the exception of an irregularly shaped area of a few

${ }^{10} \mathrm{Op.}$ cit. (Beyer and Williams), p. 430

${ }^{17} \mathrm{Op}$. cit. (Galpin), p. $67-68$.

${ }^{10}$ Baiv, H. F., Geology of Guthrie County: Iowa Geol. Survey, vol. 7, pp. 428-446, 1897. 
square miles beneath the divides of the western half.

An area of a few square miles in eastern Stuart. Approximately the northeastern quarter of Dodge.

A belt up to approximately a mile in width along the course of the Middle Racoon River in Victory.

A belt up to approximately a mile in width along the course of the South Raccoon River in eastern Valley.

A belt up to approximately 2 miles in width along the course of Beaver Creek in Beaver.

$A$ belt up to approximately a mile or more in width along the course of the valley of the Middle Raccoon River in eastern Orange and the western half of Highland.

A belt up to a mile in width along the course of the valley of Brushy Fork in northern Seeley.

Elsewhere they are covered by the Cretaceous beds. They outcrop or are overlain by only thin mantle in many places along the deeper valleys and their shorter and deeper tributaries, including those of the Raccoon, Middle Raccoon, Wichita, Beaver and Brushy Fork. In these outcrops and in the coal mining operations the series has been found to contain much shale and sandstone. Much of the shale presumably is suitable for the manufacture of heavy clay products but offers no particular advantage as to quality, location or ease of extraction. It was at one time used in a plant at Panora.

Hardin. ${ }^{19}$ Beds of the Des Moines series are believed to lie directly beneath the drift in all of Hardin County with the exception of the following township areas:

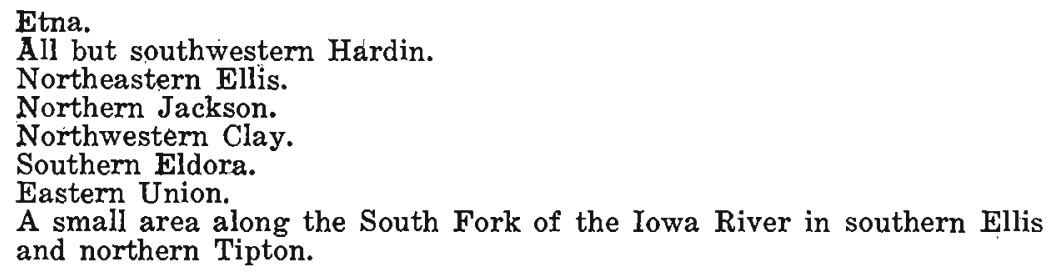

The drift cover is so thick over most of the area that the series is not exposed except along the Iowa River south of Steamboat Rock, along the lower part of some of the larger tributaries to the river in this part of its course, and along the South Fork in Ellis and Tipton Townships.

The series is known to consist of sandstone, up to 80 feet thick, and lesser amounts of shale, underclay and coal. The shale and underclay are generally beneath a considerable thickness of sandstone, thus making the shale and clay difficult to exploit.

The shale and clay have been used in the manufacture of heavy clay products at Eldora and other localities, and they have also been

${ }^{10}$ Beyer, S. W., Geology of Hardin County: Iowa Geol. Survey, vol. 10, pp. 271-278, 1900. 
used in the manufacture of pottery. There is no doubt of their suitability for these products but they are handicapped by their great depth beneath drift and sandstone, and possibly by unfavorable geographic location. From the fact that pottery was at one time successfully manufactured at Eldora the conclusion is drawn that some of the underclay is buff-burning and might be classed as a No. 2 or medium quality fire clay. Areas most likely to have least drift overburden are outside of the Wisconsin moraine, in Eldora, Pleasant, Providence and Union Townships. The shales and clays should be nearest the surface along the sides of the deeper valleys in this area.

Harrison. The extent of the Des Moines series in Harrison County is not accurately known because of the thick mantle and absence of well records. It is believed to underlie all of the county except the southeastern townships, but to be overlain in the northcentral townships by Cretaceous formations in addition to a thick layer of drift and loess. Presumably it contains abundant shales, similar to those of counties east of Harrison. The thickness of - overlying materials everywhere in the county makes them of little or no potential value.

Henry. ${ }^{20}$ Small scattered areas of the Des Moines series are present in the following township areas of southern Henry County:

\footnotetext{
Southern, western and northern Salem.

Southern and western Tippecanoe.

Southern Jackson.

Eastern Baltimore.
}

Much of the material is sandstone, although coal, shale and clay are present. The surface of the Mississippian limestone upon which the series lies is very uneven and the greater thickness of the sandstone, where it amounts to some tens of feet, is evidently due to the disposition in channels in the limestone. The areas underlain by the series are so small and the beds so thin that any shales or clays present hardly seem a likely source of raw material for a ceramic - industry.

Humboldt. The lower part of the Des Moines series extends as a narrow strip through southern Humboldt County and forms the top of the bedrock beneath the drift of the following townships :

The southern sections of Weaver and Corinth.

Most of Beaver exclusive of the northwestern sections.

The greater part of Norway.

${ }^{20 S}$ Savage, T. E., Geology of Henry County: Iowa Geol. Survey, vol. 12, pp. 284-288, 1902. 
Presumably the series here resembles that in Webster County to the south. It may also; if the same in character as the lower part of the series in Hardin County, be comprised more largely of sandstone. In any case it lies beneath such thick drift that any shales or clays present would appear to have but little potential value.

Jackson. ${ }^{21}$ This county lies east of the main area of the Des Moines series and only small outliers, none more than a few square miles in extent are present, in southern Monmouth, southern and eastern Maquoketa, and southwestern Fairfield Townships. They do not exceed 60 feet in thickness, are of the lower part of the series, and consist principally of sandstone. Small thicknesses of shale and clay are present. These are presumably suitable for the manufacture of a range of clay products, but there is nothing in their quantity, quality or location that would make their use likely.

Jasper. ${ }^{22}$ With the exception of the eastern part of Hickory Grove Township in the northeastern corner of Jasper County, the surface of the bedrock throughout is of the Des Moines series. The places where it is at the surface or close to it are, as Williams has described it, "not numerous but fairly well distributed over the southern half of the county." The best sections are along the valleys, but outcrops occur well-up toward the upland also. In the following localities it is rather well exposed:

Elk Creek Township, sec. 32.

Lynn Grove Township, sec. 31 .

Southern Richland and northern Lynn Grove Townships, along the North Skunk River and tributaries.

Mound Prairie. Township, along the Skunk River in the NW1/4 sec. 4.

There is an abundance of shales and clays in the series in these and other places in the county, of properties similar to those of Story County to the northwest, Polk County to the west, Warren County to the southwest, and Marion County to the south, in all of which they are at present being used. They were also formerly atilized in the manufacture of heavy clay products at Monroe.

Jefferson..$^{23}$ Beds of the Des Moines series form the surface bedrock beneath mantle of varying thickness throughout most of Jefferson County. The largest areas from which it is absent include parts of several townships:

Several square miles in northwestern Polk.

Approximately the northeastern quarter of Penn.

Walnut with the exception of areas of a few square miles each in northeastern, northwestern and central parts.

risavage, T. E., Geology of Jackson County: Iowa Geol. Survey, vol. 16, pp. 625-630, 1906. twilliams, I. A., Geology of Jasper County: Iowa Geol. Survey, vol. 15, pp. 810-816, 1905 .

Udden, J. A., Geology of Jefferson County : Iowa Geol, Survey, vol. 12, pp. 892-416, 1902. 
A belt up to several miles in width in northern and eastern Lockridge. A belt up to a few miles in width along Cedar Creek in Cedar. A belt up to a few miles in width along Cedar Creek and tributaries in southern Round Prairie.

The area lies along the eastern boundary of the main deposit of Des Moines rocks and only the lower part of the series totalling approximately 150 feet at the most is thus represented. Outcrops, many of them meager, are present in numerous places along the larger valleys, and the rocks of the series are mostly covered with only thin mantle along these deeper valleys. Shale and clay are present in abundance in the series in Jefferson County but there are also, in common with the lower part of the series elsewhere, comparatively large thicknesses of sandstone, with lesser amounts of limestone and coal. Several coal beds and underclays up to a few feet are known.

The brick and tile plant which formerly operated at Fairfield secured some of its clay from a pit $2 \frac{1 / 2}{2}$ miles west of Fairfield in the NE1/4 sec. 28, Center Township (T. 72 N., R. 10 W.). From the limited exposures recently available at this location it is apparent that there is present at least 5 feet of light gray to yellow shale, with a black coaly layer intercalated about 3 feet from the bottom. There may also be a thin coal on top of this shale. The material is in part an underclay and undoubtedly has the properties of a low grade fire clay. It is said to have been tried and found suitable for pottery by the plant at Fairfield.

Johnson. ${ }^{24}$ Small outliers of the Des Moines series, none of them more than a few square miles in extent, are present in Monroe, Graham, Newport and East Lucas Townships. In these areas the series is thin and there is much sandstone. Shale and clay may be present but presumably not in great thickness or of unusual quality, and the series is not considered to have potential value as a source of raw material for a ceramic industry.

Keokuk. ${ }^{25}$ This county lies along the eastern border of the main area of the Des Moines series, which directly underlies the mantle of the following township areas:

The western two-thirds of Prairie and Washington.

A belt a few miles wide extending through central Warren into Sigourney.

Southern Richland.

Southeastern Jackson.

The southwestern third of Benton.

Outliers up to a few square miles in area are found in Washington,

aCalvin, Samuel, Geology of Johnson County: Iowa Geol. Survey, vol. 7, pp. 79-88, 1897.

-2rain, H. F., Geology of Keoknk Gounty: Iowa Geol. Survey, vol. 4, pp. 283-287, 1895. 
Van Buren, Plank, East Lancaster, Clear Creek and Steady Run Townships. Only the lower part of the series having a thickness no greater than a few score feet is present. The cover of drift and loess in the county is stated to be as much as 200 feet thick in places, and it probably averages approximately 100 feet. The beds of the series are only exposed or close to the surface along the deeper valleys, but are also known from coal mining operations and from their use in the ceramic industry at What Cheer.

They contain important thicknesses of shale and clay as well as coal, sandstone and limestone. The surface upon which they lie has a relief of approximately a few hundred feet, so that individual beds are not continuous at a given horizon.

The principal and almost only use of the shales and clays of the series has been by two plants at What Cheer. The What Cheer Clay Products Company is one-half mile south of What Cheer in the NE $1 / 4$ sec. 15, Washington Township (T. 76 N., R. 13 W.). Raw material has been secured for many years from pits in the valley of Coal Creek, the present workings lying north of the plant on the east side of the valley.

\begin{tabular}{|c|c|c|}
\hline \multirow{3}{*}{$\begin{array}{c}\text { Member } \\
4 \\
3 \\
2\end{array}$} & $\begin{array}{l}\text { Section: What Cheer Clay Products Co., } \\
\text { What Cheer, Keokuk County. }\end{array}$ & \multirow{3}{*}{$\begin{array}{l}\text { Thickness } \\
\text { Feet Inches } \\
5-10 \\
2-4\end{array}$} \\
\hline & $\begin{array}{l}\text { Description } \\
\text { Alluvium and till... }\end{array}$ & \\
\hline & Coal, weathered & \\
\hline 2 & $\begin{array}{l}\text { Clay, has fracture and appearance of underclay, } \\
\text { vague stratification, somewhat silty, very tough when } \\
\text { wet, contains a few large limestone concretions up to }\end{array}$ & \\
\hline 1 & $\begin{array}{l}4 \text { feet across } \\
\text { Shale, dark blue gray, silty, sharp contact on top with }\end{array}$ & \\
\hline
\end{tabular}

These materials (members 1 and 2) are at present (1942) being removed with a dragline shovel and mixed in accordance with results desired. Yellow surface clay, presumably loessal in origin, has at times been obtained from Eddyville and used in the mixture.

Higher strata are exposed in older workings, pit No. 1, in the $\mathrm{SE}^{1 / 4}$ sec. 10.

Section: What Cheer Clay Products Co., Pit No. 1, What Cheer, Keokuk County. (1933)

\begin{tabular}{|c|c|c|}
\hline $\begin{array}{c}\text { Member } \\
\mathbf{5} \\
\mathbf{4}\end{array}$ & 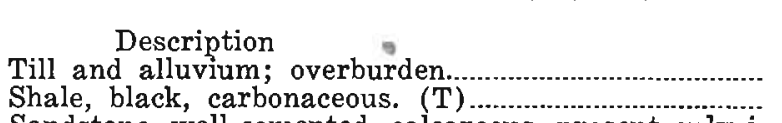 & $\begin{array}{l}\text { Thickness } \\
\text { Feet Inches } \\
5-30 \\
8-10\end{array}$ \\
\hline 3 & Sandstone, well-cemented, calcareous, present only in & \\
\hline 2 & $\begin{array}{l}\text { Coal present in south end only, apparently was cut } \\
\text { out by sandstone at the north, contains concretions }\end{array}$ & \\
\hline 1 & $\begin{array}{l}\text { up to } 5 \text { feet in diameter, this was mined by stripping. } \\
\text { Clay, underclay in character, light gray, silty. (T)... }\end{array}$ & $\begin{array}{l}5 \\
8\end{array}$ \\
\hline
\end{tabular}


Member 1 of this' section is correlated with the upper part of member 2 of the section of the present pit. It was at one time the principal raw material; member 4 was used to some extent in admixture with it. A fault of not more than a few feet throw crosses this pit in an east-west direction.

The shale or clay mix from these pits burns buff and fires to a harder product at a higher temperature than much of the shale from the series. This is related to the underclay character of part of the material. It is believed not sufficiently free of small pyrite grains to find a satisfactory use in the manufacture of fire brick or buff face brick.

The plant of John Nelson on the west edge of What Cheer also uses a few feet of weathered shale from the Des Moines series, along with surface clay, in the manufacture of tile and art pottery.

Lee. ${ }^{28}$ The Des Moines series forms the top of the bedrock beneath parts of several townships, as follows:

The western half of Cedar.

The western half of Harrison.

A belt extending northwest-southeast through Van Buren into southwestern Charleston and northwestern Des Moines.

An irregular area extending across northwestern Marion and through central Pleasant Ridge.

An irregular area which includes most of southern Marion and northwestern West Point.

A belt extending northwest-southeast through eastern Charleston.

The beds are of the lower part of the series, are believed to be not over a few score feet in thickness, and generally lie in depressions in the surface of the older rocks which has a relief of a few hundred feet. In common with the lower part of the series elsewhere there is much sandstone. Shale, coal and accompanying underclay are also present. So far as known the deposits of shale and clay are not thick or extensive and have no advantage as to quality, location or ease of exploitation.

Louisa. ${ }^{27}$ This county has two small outliers of the series only a few square miles in extent in central Oakland and southern Elm Grove Townships. They do not exceed approximately 20 feet in thickness and contain some shale, clay and coal as well as abundant sandstone. The shales and clays have little or no potential value as ceramic materials because of their limited quantity, as well as their lack of favorable geographic location.

Lucas. ${ }^{28}$ The Des Moines series forms the top of the bedrock of

${ }^{20}$ Keyes, C. R., Geology of Lee County: Iowa Geol. Survey, vol. 8, pp. 352-356, 1895

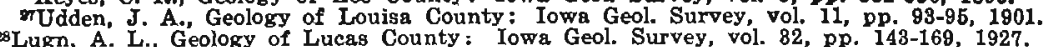


the entire county and is well known from surface exposures, drill records and coal mining operations. Good outcrops and places where the formation is covered by only thin mantle are numerous along deeper valleys in the northeastern six townships, and are also present, although to a lesser extent, in western and southern townships. The drift ranges up to 400 feet in thickness. There are no exposures of the series in Union Township and few in Otter Creek. The series increases in thickness from northeast to southwest and most of the entire thickness of approximately 750 feet is present in the southwestern part. The surface of the series and the underlying unconformity have considerable relief.

The series contains an abundance of shales and clays, as well as much sandstone and lesser amounts of coal and limestone. There are certainly shales and clays suitable for the manufacture of ceramic ware near the top of the series in the county. Whether any given locality possesses a sufficiently thick section of clay and shale, without undesirable interbedded sandstone, limestone, or coal, and lying beneath only' thin waste overburden, can only be determined by prospecting the site. There is at present no ceramic industry within the county.

Madison. ${ }^{29}$ The Des Moines series underlies all of Madison County but is overlain by beds of the Missouri series as well as by mantle over much of the area. The eastern boundary of the overlying Missouri series is very irregular. It extends east into the Des Moines area as tongues along major divides. Township areas where the Des Moines series is not covered by the Missouri series and where the Des Moines series is the top of the bedrock are as follows:

All of.Lee and Crawford.

The eastern half of Jefferson and broad belts up to a few miles wide along the major stream valleys in the western half, extending into Madison, Union and Douglas.

The eastern third of Union and broad irregular belts up to a few miles wide in the western and southern parts along North River, Cedar Creek and Middle River.

An irregular belt up to a few miles wide along North River in the eastern half of Douglas.

A belt less than a mile wide along Mìddle River in Lincoln.

An irregular area up to a few miles wide in the northern part of Scott, principally along Middle Rives and small tributaries.

$A$ belt up to approximately a mile wide along Jones Creek in the eastern half of Scott.

All of South except for tongues extending a few miles east from the western and southern boundaries between Middle River, Jones Creek and Clanton Creek.

29ilton, J. L., and Bain, H. F., Geology of Madison ,County: Iowa Geol. Survey, vol. 7, pp. 504-508, 1897 . 
An irregular area along tributaries to Clanton Creek in northern Ohio, and an irregular belt along South River and tributaries in the southeastern part.

Rocks of the series outcrop in many places over the eastern half of the county, particularly along deeper valleys such as that of Clanton Creek, and must also lie close to the surface along the sides of many of the valleys. Sections described by Tilton and Bain predominate in shale and clay; there are small thicknesses of limestone and coal, and a negligible amount of sandstone.

The following section from a ravine south of Patterson in the NW $1 / 4 \mathrm{SE}^{1 / 4}$ sec. 32, Crawford Township, (T. 76 N., R. 26 W.), is considered representative.

Member
14
13
12
11
10
9
8
7
6
5
4
3
2
1

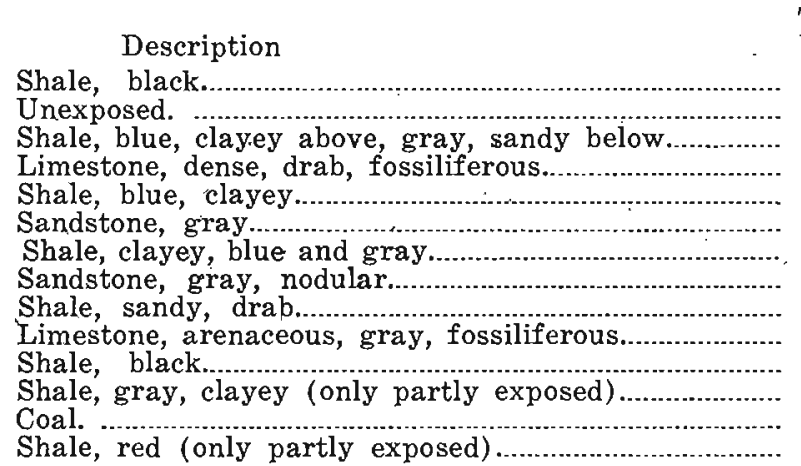

$\begin{array}{cc}\text { Thickness } \\ \text { Feet } & \text { Inches } \\ 2 & \\ 21 & \\ 16 & \\ 1 & \\ 3 & \\ 27 & 5 \\ 1 & \\ 27 & \\ 2 & 9 \\ 30 & \\ 32 & 6\end{array}$

Beyer and Williams ${ }^{30}$ have described sections on a small branch of Chariton Creek in secs. 27, 34 and 35, and north of St. Charles in sec. 11 of South Township; 2 miles southwest of Bevington on the south bank of the Middle River and south of Patterson in the NW1/4 SE $1 / 4$ sec. 32, Crawford Township.

From these outcrops it is known that the series contains an abundance of shales and clays, but apparently none is of unusual quality. The shale and clay are reasonably certain of being' as suitable for ceramic purposes as those of Dallas County to the north where they are used at Adel and Redfield. Their use involves particularly the securing of locations lacking excessive overburden or beds of useless material such as sandstone, limestone and coal. So far as known there has been no use of the Des Moines shales and clays within the county.

Mahaska. ${ }^{31}$ The top of the bedrock of this county is formed of the Des Moines series with the exception of northwest-southeast

${ }^{20} \mathrm{Op}$. cit., (Geology of Clays), pp. 447-450.

31Bain, H. F., Geology of Mahaska County: Iowa Geol. Survey, vol. 4, pp. 836-342, 1895. 
belts up to a few miles wide along the course of the North Skunk River Valley through Monroe, Pleasant Valley and Union Townships; along the course of South Skunk River Valley through White Oak, Spring Creek, Adams, Madison, Black Oak and Richland Townships; along the course of the Des Moines River through Des Moines, Jefferson and Scott Townships; and along the course of Cedar Creek in Cedar Township. The series is absent only from beneath the valley bottoms of these streams, and only the lower part, up to approximately 60 feet in thickness, is present. Outcrops and places where the shales are close to the surface are present only on the sides of the larger valleys above the beds of the Meramec series. Elsewhere the mantle of glacial drift and loess is generally thick. Coal mine workings, of which there have been many in the past, serve as an indication of the presence of these Des Moines shales below the surface. The series is known from numerous outcrops, particularly along Muchackinock Creek, and from mine shafts and records. It is known to contain argillaceous gray shale up to 30 feet thick and carbonaceous shale up to 50 feet thick, as well as considerable sandstone, coal and limestone.

The shale has been used in the manufacture of heavy clay products at Oskaloosa for many years. The plant of the Oskaloosa Clay Products Company is located immediately east of the city in the SW $1 / 4$ sec. 17, Spring Creek Township. (T. 75 N., R. 15 W.). The pit, located north of the plant on the east side of Spring Creek, exposes over 25 feet of the Des Moines series:

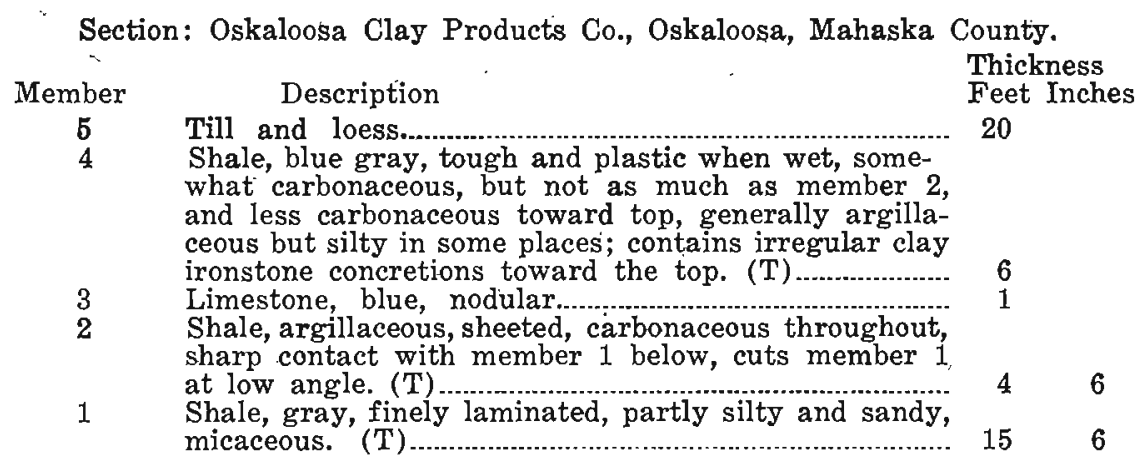

Members are used in different proportions, dependent upon the results in pressing and firing. A few years ago the blend consisted of approximately 50 percent of member 1 of the above section, 25 percent of member 2 , and 25 percent of member 3 and member 5 together. 
Clay secured in the vicinity of Eddyville in this county was at one time used in the manufacture of pottery, and no doubi clay suitable for this purpose is present elsewhere in the county within the Des Moines series. There is certainly also an abundance of shale and clay suitable for the manufacture of heavy clay products. The sections at other places, even at the same horizon, may not be the same as that described above, but is likely to contain an equally large amount of shale or clay.

Marion. ${ }^{32}$ The Des Moines series forms the top of the bedrock of Marion County except for belts up to a few miles wide along the Des Moines and Skunk Rivers and some of their larger tributaries in Lake, Clay, Prairie and Polk Townships. In the deeper parts of the valleys of these areas the Des Moines series has been removed by erosion, and the underlying beds of the Meramec series, chiefly limestone, form the top of the bedrock. Outcrops and places where rocks of the Des Moines series are close to the surface are found along sides of the deeper valleys.

The stratigraphy is known from outcrops, coal mining operations and well records. Sandstone is believed present in greater amount than in some of the surrounding counties but shales and clays of the usual range are present in abundance and have been used in the manufacture of heavy clay products at Harvey and Knoxville.

The plant of the Oskaloosa Clay Products Co., located north of Harvey on the north side of the valley of English Creek in the SW $1 / 4$ sec. 3, Clay Township (T. 75 N., R. 18 W.), is the only plant at present operating in Marion County. The pit (fig. 8) is northwest of the plant and is being extended to the west.

\begin{tabular}{|c|c|c|}
\hline & $\begin{array}{l}\text { Section: Oskaloosa Clay Products Co., } \\
\text { Harvey, Marion County. }\end{array}$ & \multirow{2}{*}{$\begin{array}{l}\text { Thickness } \\
\text { Feet Inches }\end{array}$} \\
\hline Member & Description & \\
\hline 10 & Loess and topsoil, possibly thin drift at base............... & 10 \\
\hline 9 & $\begin{array}{l}\text { Sandstone, dark red brown, weathered and crumbly, } \\
\text { contains plant impressions and carbonized fragments, } \\
\text { and weathered red sandstone fragments... }\end{array}$ & 8 \\
\hline $\begin{array}{l}8 \\
7\end{array}$ & $\begin{array}{l}\text { Coal, weathered.. silty, joint cracks near top, stained } \\
\text { Clay (underclay), }\end{array}$ & 1 \\
\hline 6 & powder, tendency toward stratification in lower part. & 3 \\
\hline 5 & $\begin{array}{l}\text { Sandstone, slabby, ferruginous, mottled, grades to } \\
\text { member } 4 \text { below and member } 6 \text { above. }\end{array}$ & $4-6$ \\
\hline 4 & $\begin{array}{l}\text { Shale, gray brown, silty, laminated, grades to dark } \\
\text { blue argillaceous zone at base..................... }\end{array}$ & 6 \\
\hline 3 & Limestone, light reddish buff, deep red brown stain & \\
\hline
\end{tabular}


a.

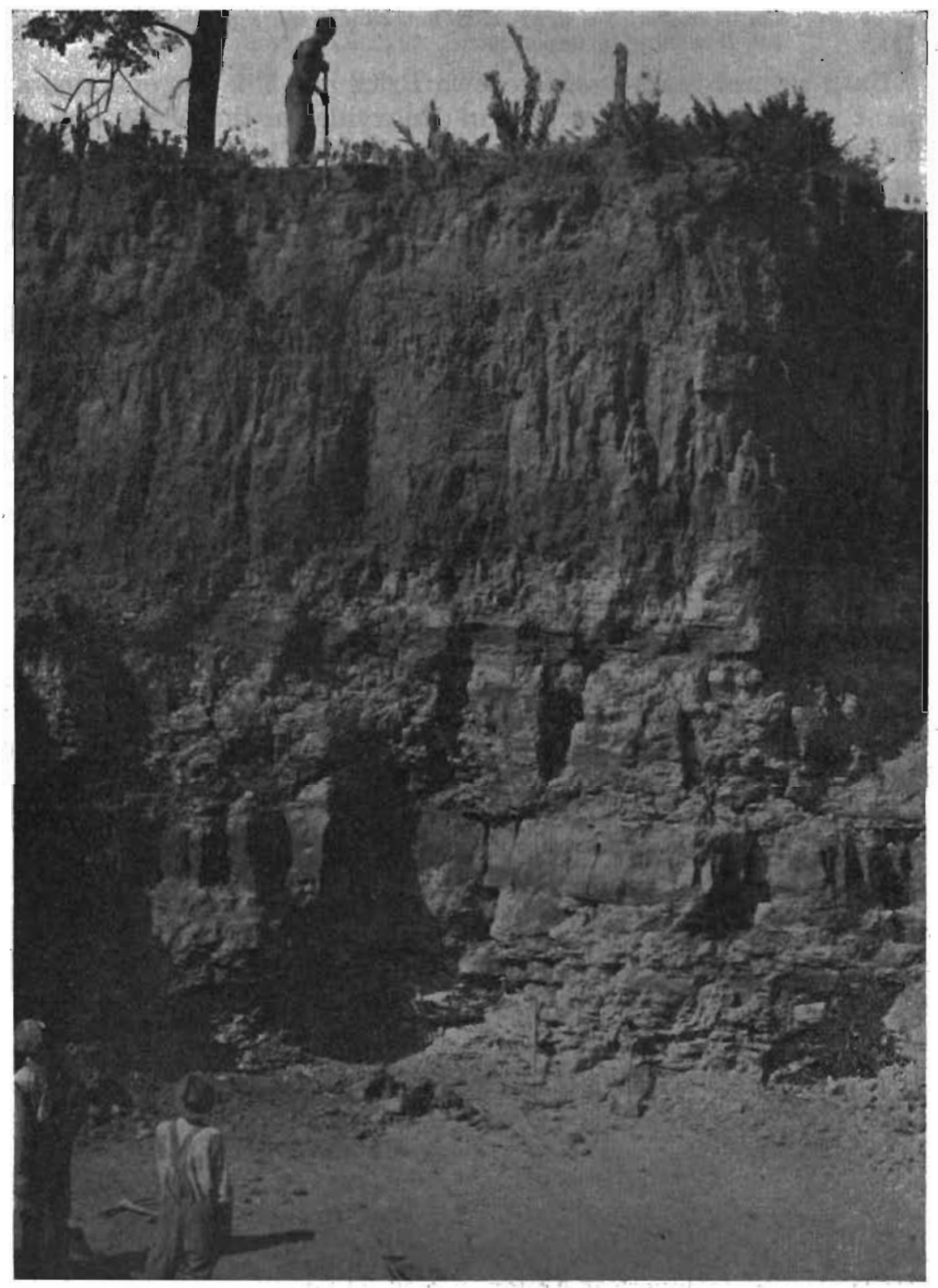

Figure 8. Shale pit of the Standard Clay Products Company, now the Oskaloosa Clay Products Campany, Harvey. Marion County. 


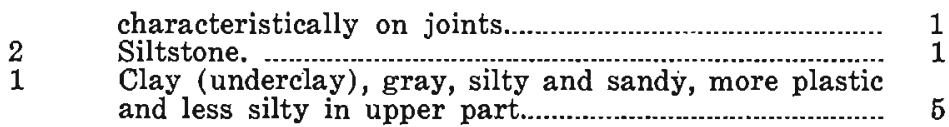

Until several years ago, the Iowa Brick and Tile Co. operated a plant in the northeastern part of Knoxville, in the NW1/4 sec. 6, Knoxville Township, (T. 75 N., R. 19 W.). The section can only be approximately described, since because of disuse the pit face had slumped considerably and become covered with slope wash.

\begin{tabular}{|c|c|c|}
\hline Member & $\begin{array}{l}\text { Section: Iowa Brick and Tile Company, } \\
\text { Knoxville, Marion County. } \\
\text { Description }\end{array}$ & $\begin{array}{l}\text { Thickness } \\
\text { Feet Inches }\end{array}$ \\
\hline & & 2 \\
\hline 3 & $\begin{array}{l}\text { Shale, gray, weathered, contains limestone concre- } \\
\text { tions and contains thin coal beds.......................... }\end{array}$ & \\
\hline $\begin{array}{l}2 \\
1\end{array}$ & $\begin{array}{l}\text { Goved. } \\
\text { Shale, light gray on weathered face, fresh material } \\
\text { in part a brownish gray, some streaks of carbona- } \\
\text { ceous shale... }\end{array}$ & 25 \\
\hline
\end{tabular}

Fire clay, according to former workmen at the plant, lies below the section given above and the buff color of ware which had been produced confirmed this. Some of the covered upper part of the section is also an underclay with fire clay characteristics.

Marshall. ${ }^{33}$ The Des Moines series forms the top of the bedrock beneath the surface materials of the following township areas:

All of Liberty, Minerva, State Center, Eden and Logan.

All of the upland area away from the valleys of the Iowa River and Honey Creek-in Bangor.

An area several square miles in the southwestern corner of Liscomb. Practically all of Iowa.

A strip approximately a mile wide in the northwestern part of Taylor.

All except a belt up to a few miles wide along the valley of the Iowa River in Nianetta.

A strip less than a mile wide along the western boundary of Linn.

The upland in the western part of Timber Creek between Linn and North Timber Creeks and between North Timber and South Timber. Creeks.

All except a few square miles in the northeastern cormer of Jefferson.

A few square miles in the southwestern cormer of Green Castle.

There is also an isolated outlier in the southwestern corner of Vienna Township, and there may be other small patches beneath the drift.

The surface materials form such a thick cover that the rocks are exposed only in a few places along some of the valleys, as along Honey Creek northwest of Albion in secs. 34 and 36, Iowa Township, (T. 85 N., R. 19 W.). According to Beyer, shales and clays are

\$8Beyer, S. W., Geology of Marshall County: Iowa Geol. Survey, vol. 7, pp. 227-229, 1897. 
numerous, but so far as known they are like those elsewhere in the series. They have not been used in the ceramic industry, and lie beneath such thick cover of drift and possibly also of sandstone that there is no incentive for using them.

Monroe. ${ }^{34}$ The Des Moines series forms the top of the bedrock beneath most of Monroe County, being absent only from an area of a few square miles in the northeastern corner of Pleasant Township. Although generally concealed beneath the mantle of drift, alluvium and loess, there are many outcrops and many places along valley sides where it is close to the surface, particularly in the northeastern townships. Definite outcrops are in part sandstone or limestone as only beds resistant to weathering are likely to appear in outcrops, and the presence of these may, as elsewhere, be taken as an indication of the possible presence near the surface of associated shale or clay. It is quite apparent, from the outcrops and coal mining records, that the Des Moines series in Monroe County contains an abundance of shale and clay suitable for the manufacture of heavy clay products. Fire clay is included in the section described by Beyer and Young ${ }^{35}$ from the vicinity of Foster. These are believed to be underclays typical of the Des Moines series, and so far as known, of the same general quality as elsewhere.

Section beneath upland near Foster, Monroe County.

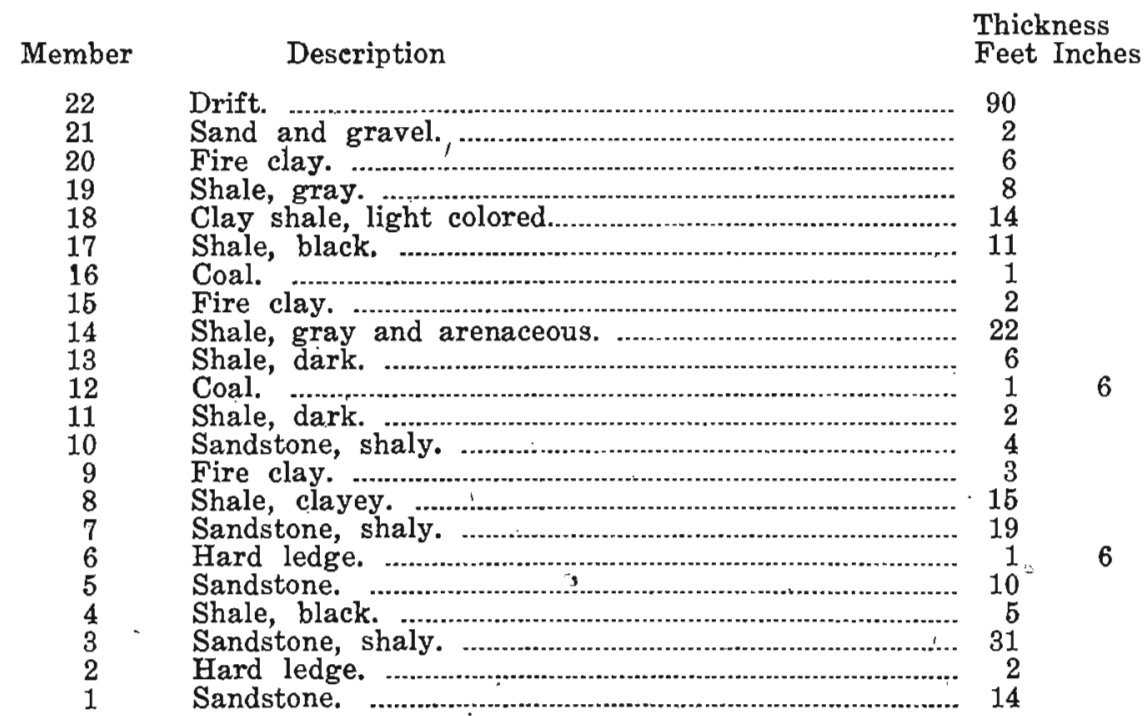

31Beyer, S. W. and Young, L. E.; Geology of Monroe County: Iowa Geol. Survey, vol. 13, pp.

$365-877,1908$.
30 Op. cit., p. 378. 
The county has at present no clay products industry and evidently has never had one which made use of the Des Moines shales and clays to any extent. Shale and clay suitable for ceramic purposes are accessible along many valleys, particularly in northeastern townships.

Muscatine. ${ }^{36}$ The rocks of the Des Moines series form the top of the bedrock over an area which includes parts of several townships:

A strip approximately a mile in width across northern Fruitland.

The southeastern half of Bloomington.

Sweetland with the exception of a narrow strip along the Mississippi River.

Montpelier with the exception of a narrow strip along the river and small areas up to approximately a square mile in extent in the northwestern part.

The southern sixth of Wilton.

The southern sixth of Fulton.

The series ranges up to approximately 100 feet in thickness and decreases rapidly in thickness toward the north. Outcrops are numerous along the deep valleys tributary to the Mississippi and are present in the bluffs, as at Wyoming Hill east of Davenport. Sandstone is prominent in many of these, attaining a thickness of as much as 100 feet. This is in keeping with the character of the lower part of the Des Moines series, of which beds in this county are a part. Shale and clay are also present and that utilized in potteries which formerly operated at Fairport was presumably underclay from the series. The thick sandstone and the lack of reasonable thickness of shale and clay in the series weighs against the possibility of extensive use of any of the materials in a ceramic industry. There is at present no clay products industry in the county.

Pocahontas. Beds of the Des Moines series are believed to underlie directly surface materials of the southeastern townships. The series boundary is not definitely known but is thought to pass northeast through Colfax and Lincoln Townships, and east through central Garfield Township. The beds do not outcrop and little is known regarding them from drilling records, but they are believed to contain shales and clays similar to those elsewhere in the northern part of the Des Moines area, as at Fort Dodge, Webster County.

Polk. ${ }^{37}$ Beds of the Des Moines series underlie the entire county. North of Des Moines the mantle is 100 feet or more in thickness and the beds outcrop only in places along the Des Moines River. In

\footnotetext{
-Udden, J. A. Geology of Muscatine County : Iowa Geol. Survey, vol. 9, pp. 808-316, 1898.
}

Orain, H. F., Geology of Polk County: Iowa Geol. Survey, vol. 7, pp. 292-302, 1897. 
the southern part of the county outside of the area of Mankato glaciation, they are exposed or are close to the surface in many places along the deeper valleys, such as those of the Raccoon and Des Moines Rivers and their deeper tributaries. Their character is known from these exposures and from many coal mining records and operations. Shales and clays are abundant close to the top of the section underlying most of the county. Thick beds of sandstone, coal in commercial thickness, and thin limestones make up the remainder.

The shales and clays have been extensively used in the clay products industry at Des Moines, and to some extent elsewhere in the county, for many years. They are at present (1942) used in the manufacture of structural clay products by the Des Moines Clay Co. and the Goodwin Tile and Brick Co., and in the manufacture of sewer pipe and tile by the Iowa Pipe and Tile Co.

The sections exposed in the shale pits of the three companies give a clear picture of the materials available in the upper part of the series in Polk County, except for places where they are cut out by channel sandstone. Two of the pits are in the northern part of Des Moines', that of the Des Moines Clay Co. on the west side of the Des Moines River Valley in the NW1/4 sec. 21, Saylor Township (T. 79 N., R. $24 \mathrm{~W}$.) and that of the Iowa Pipe and Tile Co. on the east side of the valley in the $W^{1 / 2}$ sec. 22, Saylor Township. The plant of the Des Moines Clay Co. is immediately south of its pit, while that of the Iowa Pipe and Tile Co. is a mile south of the pit and on the east side of the Des Moines River Valley at East Fourth and Hayes Streets, Des Moines.

Section: Des Moines Clay Co., Des Moines, Polk County, (1933).

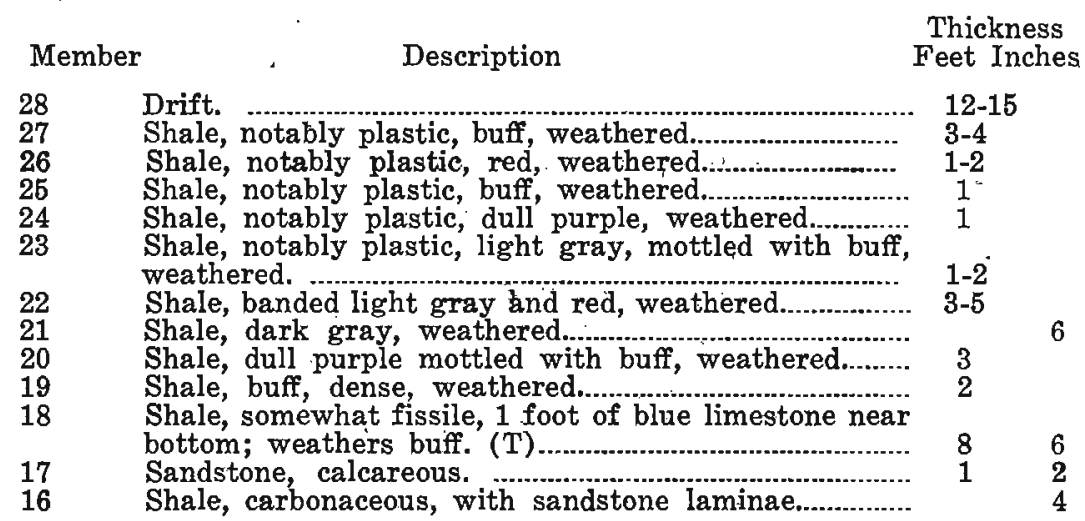


9

7

5

Clay (underclay), lower 6 inches dark blue and brown, gray above, top 1 tí feet dark gray, angular fracture, generally plastic and argillaceous but silty toward top. (T)

Shale, dull red with irregularly gray streaks, partly silty.

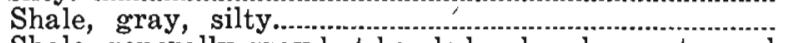
Shale, generally gray but banded red and gray toward top, fissile, weathers to flakes.

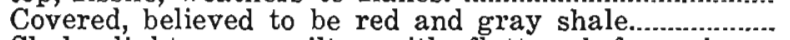
Shale, light gray, silty, with flattened ferruginous concretions.

Shale, red.

Covered, believed to be gray silty shale.

Shale, dark gray, carbonaceous, sheeted.

Coal, carbonaceous shale and sandstone irregularly interbedded.

Feet Inches

Coal.

Clay (underclay), dark gray, weathering light gray, lighter toward bottom, starchy fracture, silty, particularly in upper part. ( $\mathrm{T}$ )

Shale, carbonaceous, silty.

Shale, gray, silty, angular fracture, hard. (T)

Sandstone, noncalcareous.

3

8

The sandstone member 17 formed the floor of the pit as it was being operated in 1933, and members 18 to 27 exclusive of the limestone of 18 were being used as raw material. There were at that time two lower benches in the pit, one on top of member 7 and the other on top of member 10 . The upper members lying close to the surface are believed to have been rendered more plastic through leaching incident to weathering. Beds of this part of the section are notably different in color but believed rather alike as regards plasticity, silt content, and similar features. The various shale members of the section differ more in color than they do in properties important to the manufacturer such as plasticity and silt content. The properties of the raw material used at the plant are controlled through proper admixture of shale from different parts of the section.

The pit of the Iowa Pipe and Tile Co. had the best exposed section in 1942, standing in a vertical wall from the floor of the pit to the base of the drift. The section is much like that at the pit of the Des Moines Clay Co. and the sandstone (member 17) and the limestone of member 18 serve as horizgn markers.

The third plant is that of Goodwin Tile and Brick Co. at Southeast Eighteenth Street and Hartford Avenue in southeastern Des Moines. This is on the south side of the Des Moines River Valley in the $\mathrm{S} 1 / 2$ sec. 11 , Lee Township, (T. 78 N., R. 24 W.). A plant has operated at this locality for many years and workings from which 
shale was secured have extended. along the valley side for a few hundred yards. The present opening is immediately south of the plant.

Section: Goodwin Tile and Brick Co., Des Moines, Polk County.

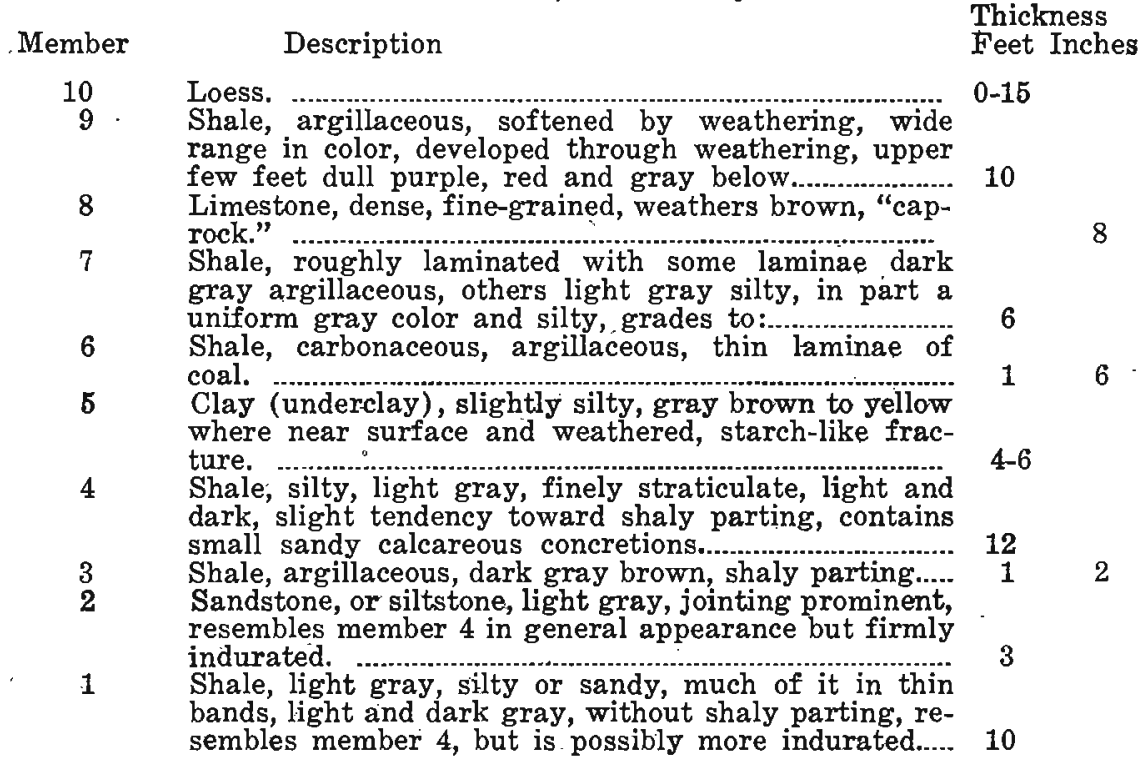

The limestone member 8 is the limestone of member 18 of the section at the pit of the Des Moines Clay Co. The three pits are thus working at approximately the same horizon in the Des Moines series. The beds above and below the limestone are, as one would expect, much alike at the three pits but vary somewhat with the character of the original deposition and the degree of weathering. The unweathered materials of the three pits, taken as a whole in each case, differ in the percentage of silt or fine sand in the composite, and in the amount of carbonaceous shale, thin coal laminae and underclay.

At the plant of the Goodwin Co. as at others, shale and clay from different horizons are mixed in proportions such as secure the most desirable results in pressing and burning. In making face tile, for example, a mixture of 30 percent of member 9 and 70 percent from below member 9 is used. Member 9 helps to produce a red color. The ware is burned at $1900^{\circ}$ to $2000^{\circ} \mathrm{F}$.

By way of summary, shale and clay suitable for heav́y clay products purposes are abundant in Polk County. They are particularly 
accessible in the vicinity of Des Moines, and their suitability there is shown by the extent to which they have been used by the industry.

Poweshiek. The Des Moines series forms the top of the bedrock beneath a considerable part of the southwestern townships, including :

The southwestern third of Grant.

All except a strip up to a mile or more in width in the northeastern corner and along the east side of Washington.

An area of less than a square mile in southwestern Pleasant.

All of Sugar Creek except a strip a mile or more in width adjacent to the course of the Skunk River Valley.

All of Union with the exception of a few square miles in the northeastern corner.

Approximately two-thirds of southern and western Jackson.

Approximately the southwestern fifth of Deep River.

The series ${ }^{38}$.is covered with thick drift beneath most of the area, but is exposed in many places along North Skunk River and Buck Creek, and it is also known from well records. The thickness of the series decreases toward the east and lies upon a surface having a relief up to as much as approximately 200 feet.

The section described by Stookey from the south bank of the Skunk River in the NW1/4 SW1/4 sec. 36, Sugar Creek Township, (T. 78 N., R. 16 W.) shows much shale and some clay, along with lesser amounts of sandstone, coal and limestone:

\begin{tabular}{|c|c|c|c|}
\hline Member & Description & $\begin{array}{l}\text { Thic } \\
\text { Feet }\end{array}$ & $\begin{array}{l}\text { mess } \\
\text { Inches }\end{array}$ \\
\hline 9 & Drift. & 8 & \\
\hline 8 & Shale. & & 6 \\
\hline 7 & Coal. & & 10 \\
\hline 6 & Limestone. & 1 & \\
\hline 5 & 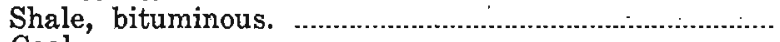 & $1 \overline{8}$ & \\
\hline 4 & Coal, & 1 & \\
\hline 3 & 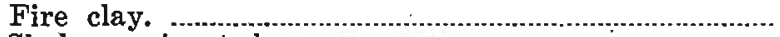 & 2 & \\
\hline $\begin{array}{l}2 \\
1\end{array}$ & $\begin{array}{l}\text { Shale, variegated. } \\
\text { Sandstone, brown. }\end{array}$ & $\begin{array}{l}7 \\
2\end{array}$ & \\
\hline
\end{tabular}

So far as known shale and clay from the Des Moines series have not been used in the manufacture of clay products in Poweshiek County. There is nothing in the quality of the shale and clay in the series, or in its location with respect to markets to make its use particularly attractive.

Sac. The boundaries of the area underlain by the Des Moines series in Sac County are not'very definitely known because of the thick drift cover and absence of outcrops, but the series is known to underlie much of the southern part. There are also large areas where it is overlain by Cretaceous beds in addition to the mantle.

\footnotetext{
88Stookey, S. W., Geology of Poweshiek County: Iowa Geol. Survey, vol. 20, pp. 258-260, 1910.
} 
It is thought to lie directly beneath the mantle of the following Township areas :

A strip less than a mile wide along the southern boundary of Boyer Valley.

A third of Jackson, in the southern and southeastern parts.

All except the northwestern approximate fifth of Cedar.

Clinton with the exception of a strip approximately one-half mile wide along the western border.

All of Wall Lake.

The northwestern two-thirds of Coon Valley.

The southeastern quarter of Wheeler.

All of Levey.

All of Viola with the exception of the southeastern quarter.

A small area not more than a square mile in extent in northwestern Sac.

The series does not outcrop in the county and but little is known of it from well records. It seems reasonable: to 'believe, however; that it has much the character of the lower part of the series elsewhere. Shale and clay probably constitute much of the upper part of the series as it is represented in the county. The material lies beneath such heavy overburden, that if for no other reason there seems little possibility of its economic use.

Scott. Only outliers or parts of outliers of the Des Moines series are present in Scott County. The largest area is part of the large outlier which extends from Muscatine County to the west; this forms the top of the bedrock beneath all of Buffalo Township except for a narrow strip a mile or two in width along the Mississippi River, with minor extensions eastward into northwestern Rockingham and southwestern Davenport Townships, and northward into southwestern Blue Grass Township. Other small outliers, none of them more than a mile or two in extent, are present in the northern and eastern parts of Sheridan and in central Lincoln, southern Le Claire and eastern Pleasant Valley Townships.

The series ${ }^{39}$ known from natural outcrops, shale pits, coal mining records and well records, totals as much as 200 feet in some places, lies upon a surface having relief of a few hundred feet, and contains, much shale and clay with lesser amounts of sandstone, limestone and coal. Until a few decades ago shale and clay secured from a pit immediately northeast of the village of Buffalo in the $\mathrm{NE}^{1 / 4} \mathrm{sec}$. 22 , Buffalo Township (T. 77 N., R. P E.) were used by the Davenport Brick and Tile Co. at its nearby plant east of Buffalo. The section as described by Norton is as follows:

soNorton, W. H., Geology of Scott County: Iowa Geol. Survey, vol, 9, pp. 463-469, 1899. 


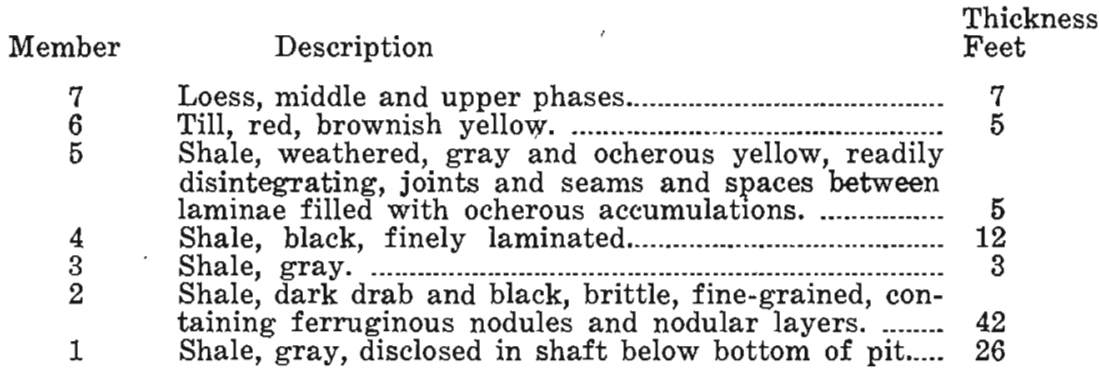

This section is believed typical of the series in the county.

Shale from this series has recently been used; along with some overlying drift, as the argillaceous constituent in the manufacture of Portland cement by the Dewey Portland Cement Co. at its plant $1 \frac{1}{2}$ miles east of Buffalo. In the clay pit, about one-half mile north of the plant, there is exposed only approximately 6 feet of a bluegray plastic clay, $(T)$, formed by the weathering of shale, and overlying drift of varying thickness.

These Des Moines shales were also used for many years in the manufacture of clay products at Island City, 3 miles southwest of Le Claire.

Shelby. Boundaries of the Des Moines series in Shelby County are not certainly known because of the thick drift and absence of outcrops. They have been located largely on the basis of well records and the southern boundary is believed to run approximately from the southwestern corner of Washington Township on the west to below the middle of the eastern boundary of Jefferson Township on the east. The series would thus form the bedrock beneath all of Grove, Union and Greeley Townships; and the northern parts of Washington, Westphalia, Douglas and Jefferson Townships. Nothing definite is known regarding the stratigraphy, but the series presumably contains shales and clays similar to those elsewhere. The beds lie, however, beneath such heavy overburden that they have little potential value.

Story. ${ }^{40}$ The county is underlain with the Des Moines series except for an area adjacent to the confluence of Squaw Creek and Skunk River valleys in the western part. While the boundaries are none too certainly known, the series is believed absent from the following township areas:

${ }^{40}$ Beyex, S. W., Geology of Story County: Iowa Geol. Survey, vol. 9, pp. 190-195, 1899. 
All of Franklin with the exception of the southwestern corner and an area of several square miles in the north.

Several square miles in the northeastern corner of Washington.

Several square miles in the northwestern corner of Grant.

A strip up to a few miles wide along the western side of Milford.

Several square miles in southwestern Howard.

Approximately a square mile of southeastern Lafayette.

Beds of the series are exposed to some extent along the Skunk River and the lower parts of some of its tributaries in the vicinity of Story City and Roland, and along West Indian Creek in the vicinity of Nevada and Maxwell. Sandstone, shale and clay make up the material of these exposures, and the shale and clay have been used in the manufacture of ceramic products at Nevada, Roland and Maxwell. The most definite information regarding the character of the shale and clay of the series has been obtained from the shale pit of F. C. McHose and Son on the west side of West Indian Creek west of Nevada in sec. 1, Nevada Township (T. 83 N., R. 23 $\dot{W}:)$, where the shales and clays have been used in the manufacture of heavy clay products for many years.

\section{Section: F. C. McHose and Son} Nevada, Story County

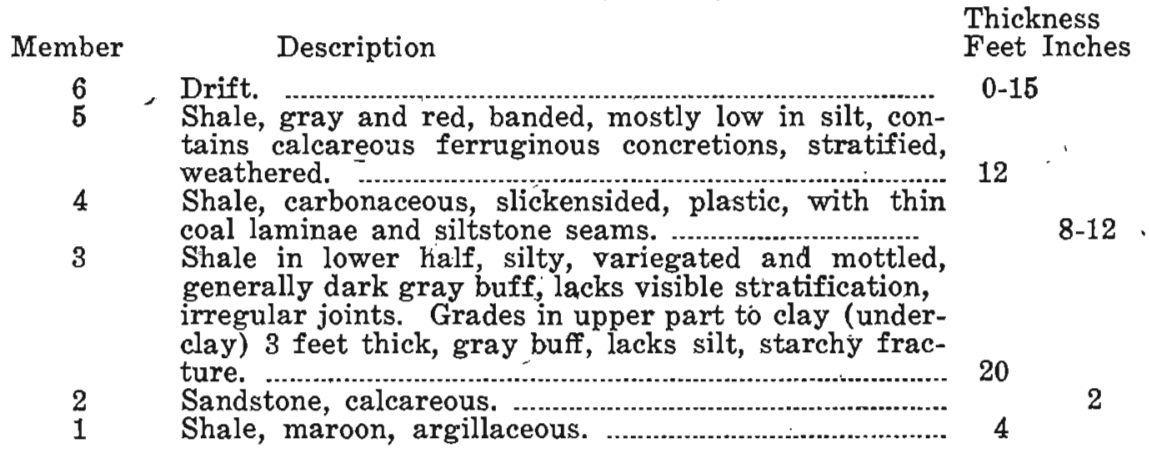

The shale and clay are undoubtedly abundant in the Des Moines series in Story County, but are almost everywhere beneath thick overburden.

Van Buren. The main area of the Des Moines series extends into Van Buren County and underlies all of the county with the exception chiefly of the country adjacent to the courses of the larger valleys. It forms the top of the bedrock of the following township areas:

Village except for a northwest-southeast strip a few miles wide adjacent to the course of Des Moines River Valley.

All of Lick Creek except a strip up to a mile or two wide along the course of Des Moines River Valley.

All of Chequest except an area of several square miles along Chequest Creek in the eastern part. 
Areas up to several square miles each in northwestern, northeastern, southwestern and extreme southern Van Buren.

The northern half of Washington.

All of Des Moines with the exception of an area of approximately a square mile in the northeastern corner.

Areas of a few square miles each in the southwestern and southeastern cormers of Henry.

Several square miles in the southwestern part of Bonaparte and a few square miles along the eastern border.

All of Union except an area of less than a square mile in the southwestern quarter.

Cedar with the exception of several square miles along the valley of Cedar Creek in the northeastern corner and an area of a few square miles in the southeastern corner.

The western third of Harrisburg except for the southwestern corner, and a strip less than a mile wide along the eastern side.

The western half of Farmington.

All of Vernon and Jackson.

Shales or clays of this series ${ }^{41}$ outcrop or are close to the surface along many of the valleys underlain by the formation. Shale similar to that in the series elsewhere is present in appreciable thickness. The thickness ranges to approximately 75 feet but is much less beneath much of the area.

Of the numerous sections described by Gordon, the following from a mine in eastern Village Township, is rather typical..

\begin{tabular}{|c|c|c|}
\hline Member & Description & $\begin{array}{l}\text { Thickness } \\
\text { Feet Inches }\end{array}$ \\
\hline 12 & Concealed. & 20 \\
\hline 11 & Shale, blue, argillaceous. & \\
\hline 10 & $\begin{array}{l}\text { Coal. } \\
\text { Shale arenaceous filled with nlant remains }\end{array}$ & 6 \\
\hline $\begin{array}{l}9 \\
8\end{array}$ & $\begin{array}{l}\text { Shale, arenaceous, tilled with plant remains... } \\
\text { Coal, }\end{array}$ & $\begin{array}{r}10 \\
6\end{array}$ \\
\hline $\begin{array}{l}7 \\
6\end{array}$ & Shale, becoming more argillaceous below.......................... & 3 \\
\hline 5 & Sandstone, filled with plant remains. & 1 \\
\hline $\begin{array}{l}4 \\
3\end{array}$ & $\begin{array}{l}\text { Fire clay, } \\
\text { Shale, black, fissile above, more compact below filled } \\
\text { with ironstone concretions, the basal portion con- }\end{array}$ & $1-2$ \\
\hline 2 & $\begin{array}{l}\text { tains lenticular masses of black calcareous rock. } \\
\text { Coal, sometimes partially cut out by the nodular }\end{array}$ & $4-5$ \\
\hline 1 & $\begin{array}{l}\text { masses above. } \\
\text { Fire clay. }\end{array}$ & $\begin{array}{c}3-4 \\
2\end{array}$ \\
\hline
\end{tabular}

More than one coal horizon, with accompanying underclay, is commonly present where the series has appreciable thickness, as in the above section. Attention has frequently been attracted to the occurrence of light colored, buff-burning clays suitable for the manufacture of pottery and formerly used in its manufacture in this part of Iowa where the lower part of the series is represented. The county is in the area included by Galpin in his exploration for satisfactory No. 1 fire clay. ${ }^{42}$ The underclays from Van Buren and

'Gordon, C. H., Geology of Van Buren County: Iowa Geol. Survey, vol. 4, pp. 222-229, 1895. 20p. cit., pp. 67-75. 
adjoining counties tested by Galpin were found not sufficiently refractory for the manufacture of high grade refractories although a buff-colored product was secured. These clays are believed to be more common in the lower part of the series and to be more accessible in southeastern Iowa than in areas farther west.

Beds of the series have been exposed in a ravine approximately 1 mile north of Farmington in the NW1/4 sec. 36, Farmington Township, (T. 67 N., R. 8 W.), in a locality where there has been considerable coal mining. Five and one-half feet of light gray sandy clay of the type tested by Galpin is exposed beneath black carbonaceous shale. It is stained yellow with limonite along cracks, has many streaks of carbonaceous material in the upper part, is quite sandy in places, and free from sand or silt and very plastic in others; it is partially indurated and almost a sandstone in places; stratification is vague. The material lies upon a black, sheeted shale and this in turn upon St. Louis limestone. This is believed to be of approximately the same quality as other light colored clays reported by Galpin.

Similar clays are also present along a ravine in the vicinity of coal mine workings about 2 miles northeast of Bonaparte in the NW1/4 sec. 4, Bonaparte Township, (T. 68 N., R. 8. W.), on a farm operated in 1935 by Guy and Joe Lydolph.

\begin{tabular}{|c|c|c|}
\hline Member & Description & $\begin{array}{l}\text { Thickness } \\
\text { Feet }\end{array}$ \\
\hline 6 & $\begin{array}{l}\text { Sandstone, not visible, reported to form good roof for } \\
\text { coal mining. }\end{array}$ & 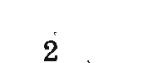 \\
\hline $\begin{array}{l}5 \\
4\end{array}$ & Clay (underclay), light gray, plastic, slightly silty, & $2-232$ \\
\hline 3 & $\begin{array}{l}\text { Shale, carbonaceous, thin seams of coal at bottom in } \\
\text { some places. }\end{array}$ & $5-6$ \\
\hline 2 & $\begin{array}{l}\text { Clay (underclay), very light gray, blue gray, dove, } \\
\text { or gray brown, slightly silty, plastic, nodular frac- } \\
\text { ture, pyrite in grains, large limestone concretions } \\
\text { in places at top. }\end{array}$ & $4^{1 / 2-6}$ \\
\hline 1 & 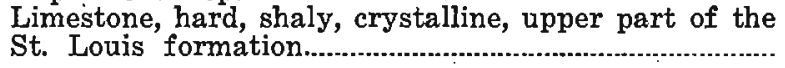 & \\
\hline
\end{tabular}

These underclays are believed similar to others tested by Galpin, to be unsuited to the manufacture of refractories because of the presence of pyrite, and to rate as a No. 2 or No. 3 fire clay.

Clay once used in a pottery at Bonaparte, and secured approximately a mile north of the locality of the above section, in the NE1/4 sec. 33, Harrisburg Township (T. 69 N., R. 8. W.), is believed to have come from this horizon.

Summarizing, it is apparent from Galpin's tests and from further 
exploration that buff-burning clays of fair quality occur in this county. They are not believed sufficiently free from impurities to be usable in the manufacture of refractories. They are also generally beneath considerable overburden and offer no particular advantage from the standpoint of markets or transportation.

Wapello. The Des Moines series underlies most of the county. The largest area from which it is absent is a strip up to several miles in width extending adjacent to the course of the Des Moines River Valley from the northwestern corner of the county to below Ottumwa. In this area it is absent from the following township areas:

All of Columbia except for areas of several square miles in the southwestern and northeastern corners.

An area of a few square miles in the vicinity of Avery Creek in northern Cass.

A few square miles in southwestern Richland.

A northwest-southeast strip up to a few miles wide through Center.

Other areas from which it is absent include one of a few square miles about the headwaters of Cedar Creek in Richland Township, and a strip up to two miles in width along the north border of Competime Township.

The series ${ }^{43}$ is believed to have a maximum thickness of 250 feet in Wapello County and to average approximately 175 feet. There are many outcrops of the beds of the series along the larger valleys and many places where they are covered with only thin overburden along such valleys. Artificial exposures made for railroads, highways and ceramic plants have also been numerous. Much massive sandstone, channel in character, is known, particularly from outcrops along the Des Moines River. Black carbonaceous fissile shale makes up a considerable pereentage of the shale beds near the surface. Other shales and clays, both, silty and argillaceous, and of considerable range in color, are also known to make up an appreciable part of the near-surface.Des Moines series.

Ceramic plants using material from the Des Moines series have at one time or another operated elsewhere in the vicinity of Ottumwa, but at present there is only the plant of the Ottumwa Brick and Tile Co. just west of the city limits. This plant has operated since 1890. Shale and clay, were secured until recent years from a pit north of the plant on the east side of a small valley tributary to that of the Des Moines River in the NE1/4 sec. 14, Center Township. The company is at present (1942) securing raw material from a pit on the southeast side of a small valley tributary to the Des Moines

43Leonard, A. G., Geology of Wapello County: Iowa Geol. Survey, vol. 12, pp. 458-471, 1902. 
River in the NW1/4 sec. 2, Center Township, (T. 72 N., R. 14 W.). The sections at these localities are given below:

Section: Ottumwa Brick and Tile Co., Ottumwa, Wapello County. (Pit in sec. 14, immedately west of city limits, 1933.)

\begin{tabular}{|c|c|c|c|}
\hline Member & Description & & Iness \\
\hline $\begin{array}{l}5 \\
4 \\
3\end{array}$ & $\begin{array}{l}\text { Loess and thin drift. } \\
\text { Shale, light gray, silty, softened by weathering.... } \\
\text { Shale, banded gray and red, (T), black, sheeted at } \\
\text { bottom. }\end{array}$ & $\begin{array}{r}4 \\
10\end{array}$ & \\
\hline $\begin{array}{l}2 \\
1\end{array}$ & $\begin{array}{l}\text { Coal. (underclay), light gray, silty, carbonized plant } \\
\text { fragments near top, upper } 10 \text { inches contain coal } \\
\text { laminae. }\end{array}$ & 2 & 4 \\
\hline
\end{tabular}

The workings at this pit (fig. 9) are extensive and the bottom of the unused portion lies approximately 30 feet below the above section, indicating that shale and clay were once used from that depth. In 1935 material was being secured from the south end of the pit, and only members 3,4 , and 5 of the above section were being used.

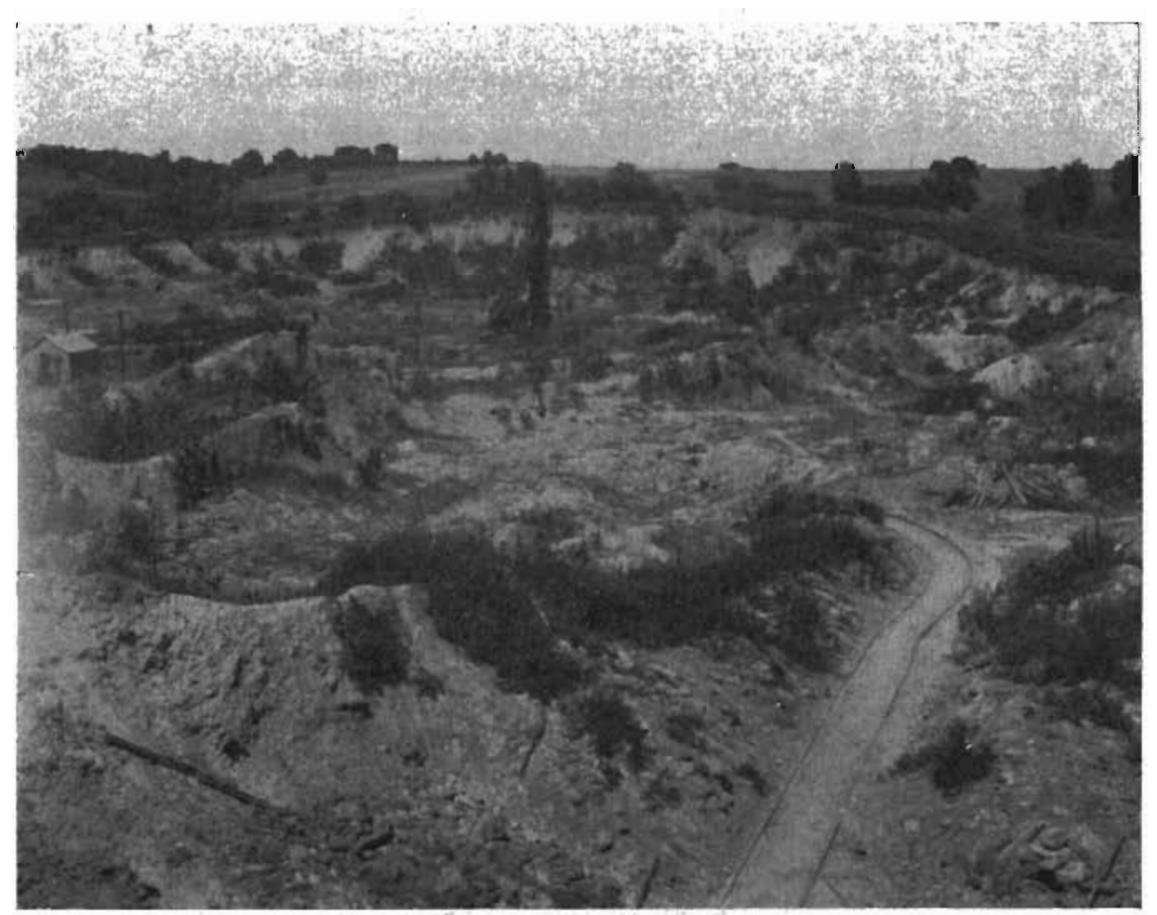

Figure 9. General view of extensive abandoned workings in the sbale pit of the Morey Clay Products Company, now the Ottumwa Brick and Tile Company, Ottumwa, 
Bricks from member 1 were buff, speckled with brown spots from the burning of pyrite; these were said to have given satisfactory service as fire brick at the plant and in bakery ovens at Ottumwa. The upper part of member 4 is stated to have once been used in the manufacture of pottery.

Section: Ottumwa Brick and Tile Co., Ottumwa, Wapello County.

(Pit in sec. 2, Center Township, northwest of Ottumwa).

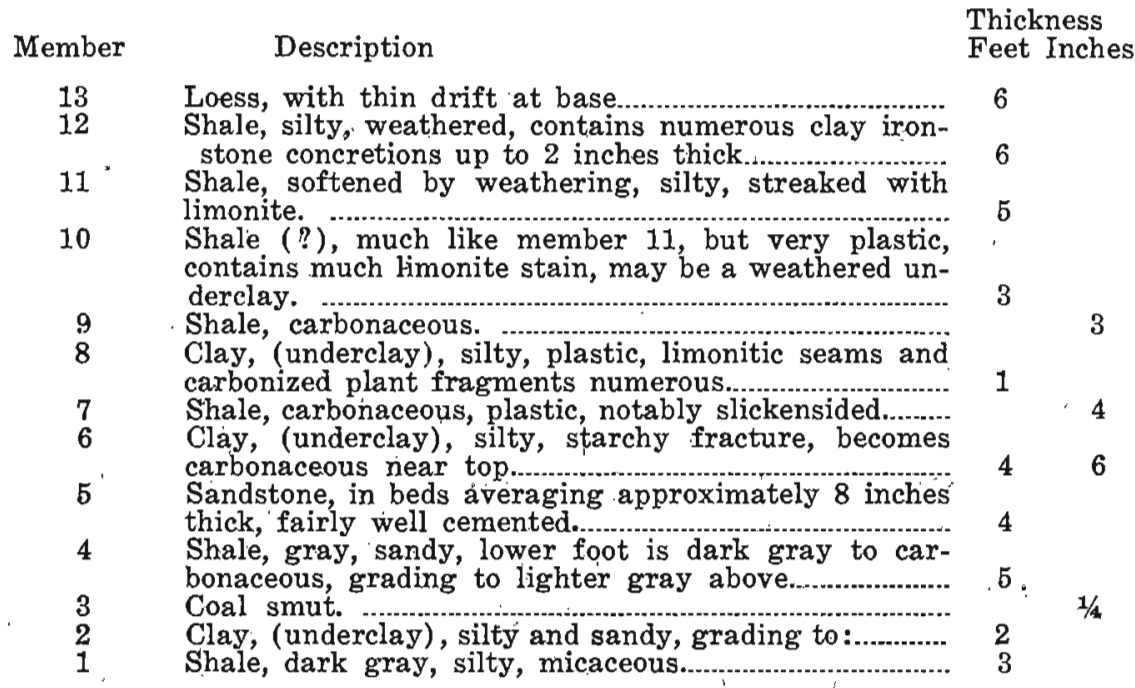

Members 12, 13, and part of 11 constitute stripping; the sandstone member 5 , is also rejected. This section contains sufficient clay of an underclay type so that buff-burning ware can be produced from it. The material is trucked to the plant in Ottumwa.

There is abundant shale and clay suitable for ceramic uses in the Des Moines series of Wapello County, and there are undoubtedly many localities, determinable only by exploration, where they lie beneath thin overburden. Whether beds of undesirable sandstone, carbonaceous shale and limestone are present can also be determined only by exploration.

Washington. Only a few small outliers of the Des Moines series, none more than a few square miles in extent, are present in Washington County; one in southern Clay Township; one in northern Oregon Township; and two in Highland Township, one in the central and the other in the southeastern part. The extreme southwestern corner of Clay Township is also underlain by a few square miles of the main area of the Des Moines series. These areas, in 
common with the lower part of the series in southeastern counties, contain notable amounts of sandstone and underclay as well as lesser amounts of shale and coal. So far as known the shales and clays have not been used for ceramic purposes and the occurrences appear to hold no particular promise of profitable use.

Warren. The Des Moines series forms the top of the bedrock beneath all of Warren County. It outcrops ${ }^{44}$ or is beneath only thin overburden in many places along the valleys of North, Middle and South Rivers and their larger tributaries, in places where the drift has been removed by fluvial erosion.

Sections described by Beyer and Williams ${ }^{45}$ are given below.

Sec. 15, Allen Township.

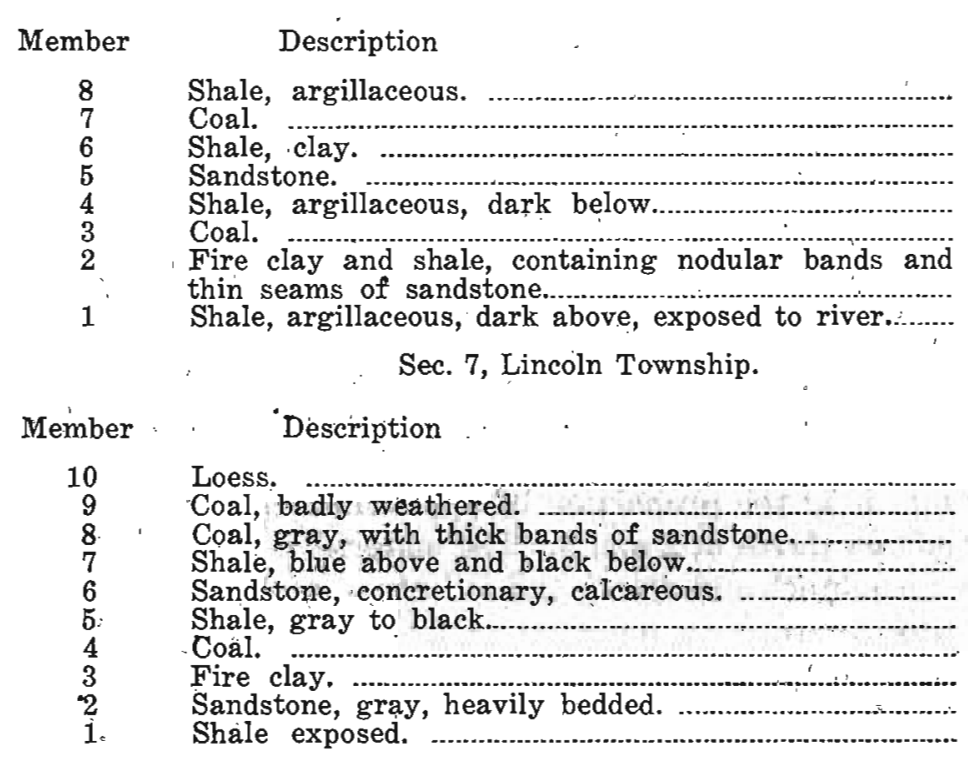

Thickness

Feet Inches

Shale, arg

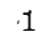

Shale clay.

10

$1 \quad 6$

Shale, argillaceous, dark below

Sec. 30, Greenfield Township.

Member Description

Thickness Feet Inches

Coal, impure and weathered.

Shale, compact above and soft below.

2

Sandstone, gray.

Shale, argillaceous, blue, exposed.

From these outcrops, from others described by Tilton, and from mining records and well records, the series is known to consist

4Tilton, J. L., Geology of Warren County: Iowa Geol. Survey, vol. 5, pp. 303-358, 1896. 40 p. cit., pp. $490-493$. 
chiefly of shale with lesser amounts of clay, sandstone, coal and limestone, totalling several hundred feet.

The shales and clays of the series were at one time used in the manufacture of ceramic ware at Hartford and are at present used at Carlisle in the manufacture of heavy clay products by the Carlisle Brick and Tile Co. Raw material is secured from a pit on the east bank of North River Valley, in the NE1/4 sec. 4, Allen Township, (T. 77 N., R. 23 W.). The following is an approximate section at the face of the pit.

Section: Carlisle Brick and Tile Company, Carlisle, Warren County (1935).

\begin{tabular}{|c|c|c|}
\hline Member & Description & $\begin{array}{l}\text { Thickness } \\
\text { Feet Inches }\end{array}$ \\
\hline 8 & Loess. & $0-3$ \\
\hline 7 & Drift. & $0-3$ \\
\hline $\begin{array}{l}6 \\
5\end{array}$ & $\begin{array}{l}\text { Shale, gray, laminated. } \\
\text { Coal and carbonaceous shale. }\end{array}$ & 4 \\
\hline 4 & $\begin{array}{l}\text { Clay (underclay), light gray but streaked with yel- } \\
\text { low brown on weathered face, silty, plastic......................... }\end{array}$ & 5 \\
\hline 3 & $\begin{array}{l}\text { Shale, gray, very silty and sandy, almost sandstone } \\
\text { in places. }\end{array}$ & 3 \\
\hline 2 & $\begin{array}{l}\text { Shale, gray, laminated; silty, contains irregular cal- } \\
\text { careous concretions. }\end{array}$ & 6 \\
\hline 1 & Covered, to river level. & 50 \\
\hline
\end{tabular}

Coal mined nearby evidently lies within the covered part of the above section and is believed underlain in turn by light gray underclay.

The raw mix is in the proportion of approximately one-third of member 4 and two-thirds of 2 and 3 . The material is said to handle well in auger machines and driers and is burned at $1960^{\circ} \mathrm{F}$.

- Summarizing, there is an abundance of shale and clay suitable for the ceramic industry in the Des Moines series in Warren County, and there are many places on the sides of the deeper valleys where it lies beneath comparatively thin overburden.

Wayne. ${ }^{46}$ The Des Moines series forms the top of the bedrock beneath the entire county. The drift cover is thick, however, and the only outcrops, chiefly limestone, are in the northeastern corner. From well records and coal mining operations, however, the series is known to contain an abundance of shale and underclay. They are everywhere so thickly covered with drift that their use is not considered a likely one.

Webster. The exact boundaries of the area of the Des Moines series in Webster County and the extent to which it is overlain by

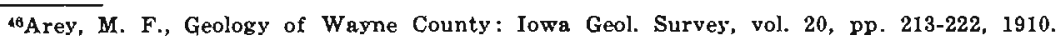


the Fort Dodge gypsum beds are not accurately known because of the considerable thickness of glacial drift over most of the county and the absence of outcrops except along the valley of the Des Moines River. The series is believed to form the top of the bedrock of mast of the county, but is absent from a strip a mile or more in width adjacent to the Des Moines River and the lower part of some of the larger tributaries from the northern boundary to a point a few miles south of Fort Dodge. It is thus absent from eastern Deer Creek Township, northwestern and southwestern Badger, northwestern Douglas, and eastern Cooper. It is also believed absent from an area of a few square miles in southern Elkhorn and northern Clay Townships.

The Des. Moines series is overlain by gypsum beneath an area of several square miles in the vicinity of Fort Dodge, which includes southeastern Douglas, southwestern Fulton and northwestern Elkhorn; and from a larger area which includes much of central and southwestern Cooper; and small areas along the western side of Colfax and the northern side of Otho Townships.

The series ${ }^{47}$ is exposed only along the Des Moines River and some of its larger tributaries south from the vicinity of Fort Dodge. Only the lower part of the series is present, with thickness of as much as 100 feet. Much information regarding the series has been obtained from the natural exposures, coal mining and clay working operations and well records. The series here includes thick beds of shale and underclay, as well as much sandstone and coal, and some limestone. The sections at the shale pits of the ceramic plants at present operating, of which there are four, serve to illustrate the materials present and used by the ceramic industry.

The three plants in the vicinity of Fort Dodge are the Vincent Clay Products Co., with plant and pit a few miles southeast of Fort Dodge on the east side of Des Moines River Valley in the SW1/4 sec. 6, Pleasant Valley Township, (T. 88 N., R. 28 W.) ; the Johnston Clay Works with plant and shale pit approximately 4 miles southeast of Fort Dodge on the west side of Des Moines River Valley in the SW.1/4 sec. 8, Otho Township (T. 88 N., R. 28 W.) ; and the Kalo Brick and Tile Co., with plant approximately 5 miles southeast of Fort Dodge on the west side of Des Moines River Valley in the SE $1 / 4$ sec. 17, Otho Township and the pit across the river in the NE $1 / 4$ sec. 17, Pleasant Valley Township (T. 88 N., R. 28 W.). These sections, though not located more than a few miles apart, have not been definitely correlated because of the lack of persistent key beds.

ITWilder, F. A., Geology of Webster County: Iowa Geol. Survey, vol. 12, pp. 83-99, 1902. 
Section: Vincent Clay' Products Co., Fort Dodge, Webster County.

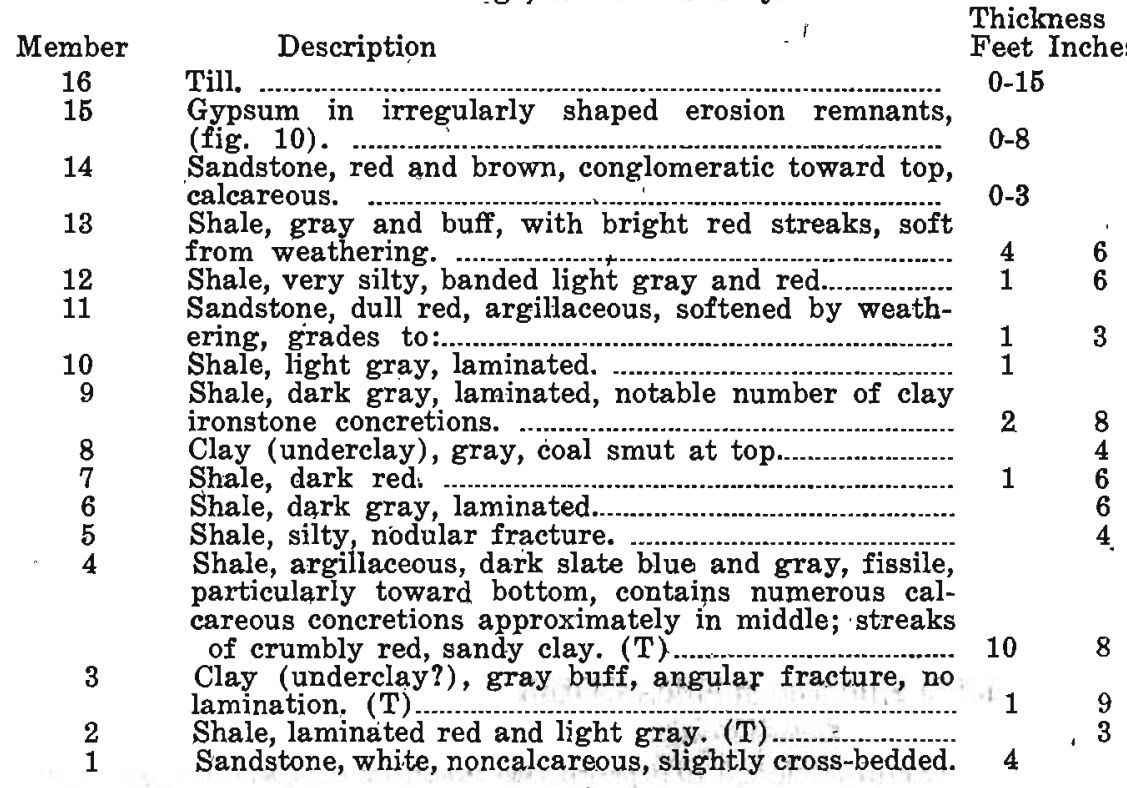

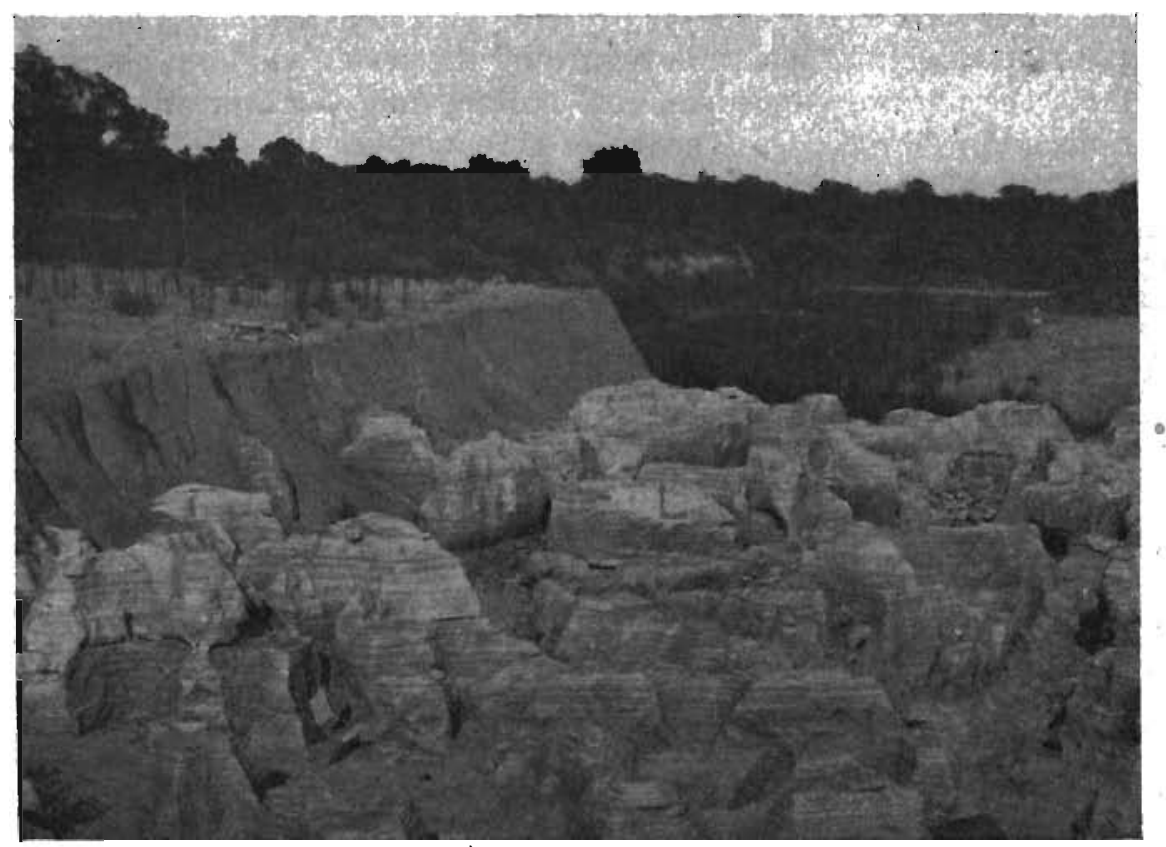

Figure 10. Gypsum above the shale pit of the Vincent Clay Products Company, near Fort Dodge, Webster County. 
Abandoned parts of the pit in 1932 showed 1 foot of coal above member 2 of the above section, in turn overlain by black sheeted shale. The described section contains a large number of members for the thickness involved. These are based largely upon color differences which are very clear, since the pit is operated by a planing machine, but these shale members do not differ appreciably in ceramic properties. The upper part of the section exposed in 1942 is somewhat different from that described above since the pit has been extended north and east, and is thinner and more affected by weathering. In 1935 members 2 to 13 inclusive were being used in the mix.

During the past two years the company has been using a No. 3 fire clay or potter's clay, secured from a drift mine in the hillside north of the plant, in the production of a cream- to buff-colored ware. The shale from the pit and the clay from the mine are treat, ed by the same methods, ${ }^{48}$ are considered equally plastic, and are burned at approximately $2000^{\circ} \mathrm{F}$., with total shrinkage of 14 percent.

The section at the pit of the Johnston Clay Works is believed to lie at approximately the same horizon as that of the Vincent Clay Products Co.

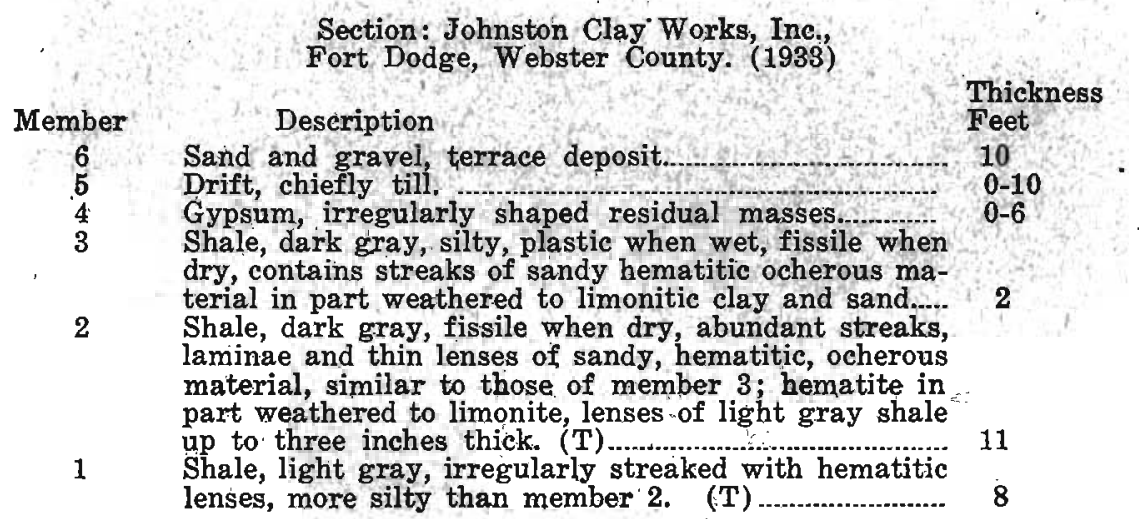

The differences between the members of the foregoing are probably minor from the clay worker's viewpoint. Working at approximately the same level, the section today (1942) is believed to differ somewhat from the above. This is to be expected since the original character and thickness of members may be expected to vary somewhat, the effect of weathering varies, the pit face may be higher or lower in the section, and faults may cross the area.

${ }^{40}$ Communication from Mr. O. J. Whittemore. 
In 1942 the base of the pit face was somewhat lower than in the section described, so that 4 inches of coal and carbonaceous shale overlying 6 inches of underclay were exposed. Two faults along which there had been movement of a few feet, were also apparent, although not clearly exposed. The sandstone (member 1) of the Vincent Clay Products Co. section is believed to lie below the section of the Johnston pit.

In 1933 members 1, 2 and 3 of the section were being used in the plant mix. In addition, material from an opening east of the above and nearer the plant, was added to reduce shrinkage in the product. It was a light gray and sandy shale, with the hematitic and orcherous streaks of the foregoing section, believed to be a weathered phase of member 2. At present ${ }^{40}$ (1942) approximately 50 percent each of members 1, 2 and 3 together, are used. The ware is burned at $2100^{\circ}$ to $2300^{\circ} \mathrm{F}$., with shrinkage of approximately 12 percent.

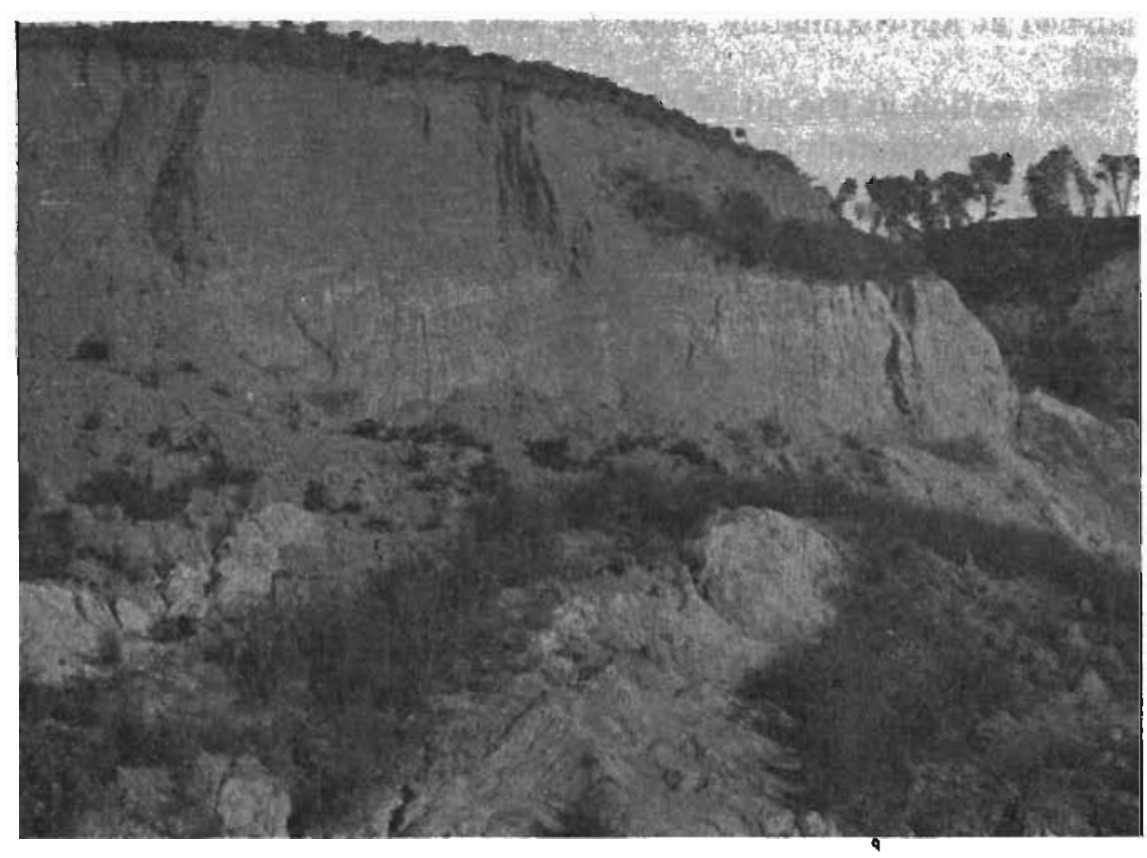

Figure 11. Thick glacial drift and chainnel sandstone in the shale pit of the Kalo Brick and The section at the pit (fig. 11) of the Kalo Brick and Tile Co., although but approximately a mile to the southeast, bears little resemblance to that of the Johnston Clay Works.

${ }^{49}$ Communication from Mr. G. L. Johnston. 
Section: Kalo Brick and Tile Company, Kalo, Webster County. (1933)

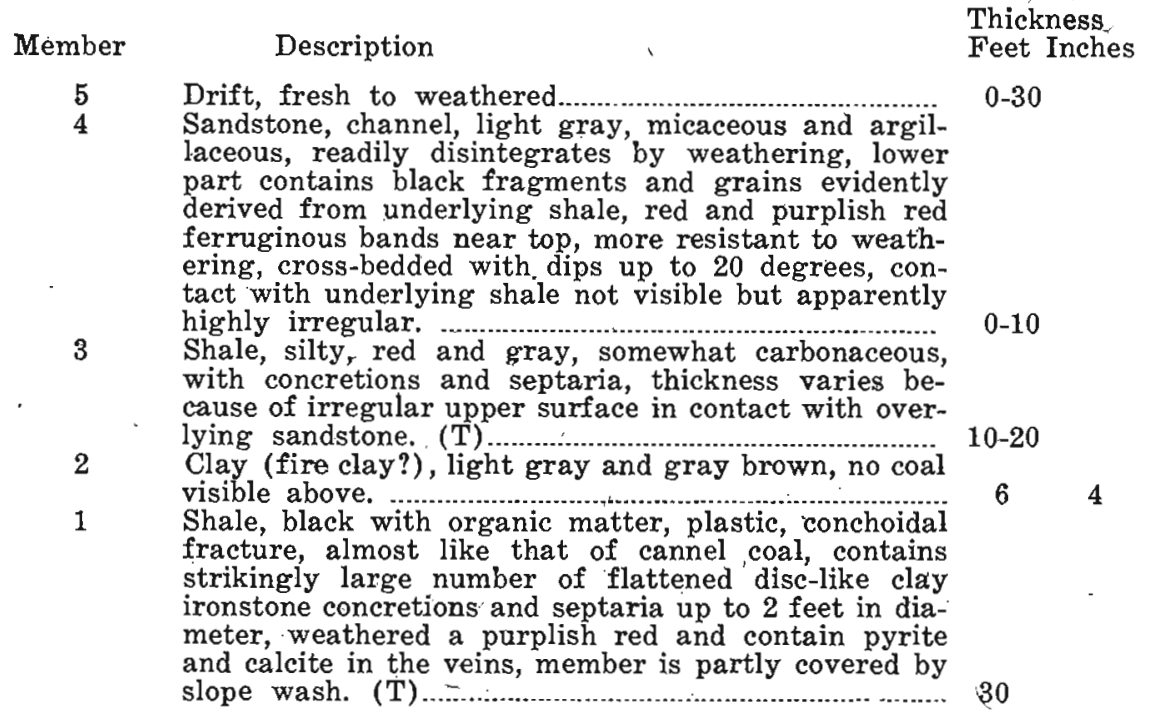

Members 1, 2 and 3 were being used in the plant mix in 1933. The concretions were separated by hand and had accumulated in large numbers on the floor of the pit. Drift overburden was being removed by hydraulic methods.

By 1942, with extension of the pit face to the east into the side of the valley, the thickness of the channel sandstone (member 4) had increased to approximately 15 feet. Septaria and other concretions were no longer present in abundance in members 1 and 3 . Lenses of weakly cemented white sandstone, up to a few feet thick, had made their appearance in the lower part of member 1 which however was not worked to the same depth as in 1933.

At present (1942) the different members are mixed in proportions such as will produce the desired result. A mix ${ }^{50}$ consisting of 15 percent of member 1,35 percent of member 2 and 50 percent of member 3 is used for much of the ware. Kilns are burned at 1850$2050^{\circ} \mathrm{F}$.

Raw material was secured prior to 1918 from a pit on the west side of the river, probably abaridoned because of increasing thickness of overburden. Shale is at present moved across the river to the plant by aerial tramway.

The southernmost plant of the county is that of the Lehigh Sewer

${ }^{60}$ Communication from Mr. G. E. Schnurr. 
Pipe Co., approximately a mile southwest of Lehigh in the valley of Crooked Creek, with pit on the narth side of the valley in the NW1/4 sec. 13, Sumner Township, (T. 87 N., R. 28 W.).

Section: Lehigh Sewer Pipe Company,

Lehigh, Webster County. (1933)

\begin{tabular}{|c|c|c|c|}
\hline Member & Description & \multicolumn{2}{|c|}{$\begin{array}{l}\text { Thickness } \\
\text { Feet Inches }\end{array}$} \\
\hline $\begin{array}{l}13 \\
12\end{array}$ & Drift, principally till, unweathered in lower part..... & $0-30$ & \\
\hline & 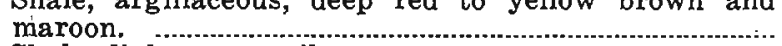 & 3 & 6 \\
\hline 11 & Shale, light gray, silty. ................ & & \\
\hline 10 & 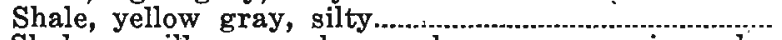 & 3 & 6 \\
\hline 9 & Shale, argillaceous, deep red or maroon, irregular & & \\
\hline 8 & Shale, sandy, massive, finely banded light and dark & & \\
\hline 7 & $\begin{array}{l}\text { gray, almost an argillaceous sandstone. } \\
\text { Shale, argillaceous, finely banded yellow, gray, dull }\end{array}$ & 5 & \\
\hline 6 & $\begin{array}{l}\text { red, dull purple, fissile. } \\
\text { Clay (underclay?), sandy, light gray, irregular frac- } \\
\text { ture, no coal smut visible above. }\end{array}$ & $432-5$ & 6 \\
\hline 5 . & $\begin{array}{l}\text { Clay (underclay ?), sandy, dull purple, irregular frac- } \\
\text { ture. }\end{array}$ & & \\
\hline $\begin{array}{l}4 \\
3 \\
\mathbf{2}\end{array}$ & $\begin{array}{l}\text { Shale, argillaceous, buff, fissile. } \\
\text { Sandstone, shaly, gray. } \\
\text { Sandstone, light gray, weakly indurated, partly cäl- }\end{array}$ & 4 & \\
\hline & Shale, buff at top, grading to carbonaceous below.... & $\begin{array}{l}3 \\
6\end{array}$ & \\
\hline
\end{tabular}

All of this section was being used in the plant mix except the indurated parts of members 2 and 3 . This section contains shale beds which are quite unlike in color and to a lesser degree in content of silt and sand. These differences, as elsewhere, are not appreciable in terms of ceramic properties. In any case the properties of the finished product may be controlled by proper admixture of material from the different horizons which may vary somewhat in plasticity, amount of shrinkage in the ware, and in other properties.

This vicinity has been the scene of a ceramic industry for several decades, and the side of the valley of Crooked Creek has been worked for shale and clay for many hundreds of feet. Because of the steepness of the valley sides the thickness of the drift overburden increases rapidly in short distances, so that any clay pit may expect to encounter this difficulty as it is extended into the valley side. The abundance and desirability of the raw material are apparent however from the history and extent of the industry here:

Summarizing, the shales and clays of the Des Moines series in Webster County contain an abundance of shale as well as, in some places, of underclay capable of producing a buff ware. They lie reasonably close to the surface on the sides of the deeper valleys such 
as that of the Des. Moines River and of the larger tributaries in their lower courses. The difficulty of increasing thickness of overburden is likely to arise as the workings from which shale and clay are secured is extended into the valley sides. The abundance and good quality of the material for the manufacture of heavy clay products is apparent from the history of the industry in the county.

Wright. The Des Moines series forms the top of the bedrock beneath heavy glacial drift in a belt extending through the southern townships. Boundaries are not certainly known because of the thick blanket of glacial drift and lack of outcrops, but the series is thought to underlie the following township areas:

The southwestern third of Eagle Grove.

All of Troy.

Woolstock with the exception of a narrow strip up to a mile in width along the northern boundary.

Wall Lake with the exception of a strip 2 miles long along the northern boundary.

The beds do not outcrop and little has been learned regarding chem from drilling records. While the series in this area is believed to contain an abundance of ceramic shales and clays, somewhat resembling those of the vicinity of Fort Dodge, they are inaccessible because of the generally thick overburden.

Summary. Shales and clays of the Des Moines series. Wherever the Des Moines series is present in appreciable thickness there is included a high proportion of shale and a smaller proportion of underclay, buff-burning and of somewhat refractory properties but still unsuited for high grade products. The lower 200 feet of the series is thought to contain more sandstone and underclay than that higher in the section. The shale and underclay are suited to the manufacture of a wide range of heavy clay products.

Because of the relatively thick mantle of the area north of Des Moines, beds of the series are generally inaccessible except in a relatively few places where deep valleys have been incised to their level. Most of the southern counties have many places where they are accessible along valleys. In the southwestern part of the State they are inaccessible for all practical purposes because of the thick martle. In the southeastern part they are again rather widely exposed or near the surface but many of the exposures are of sandstone and the deposits are comparatively thin.

SHALES AND CLAYS OF THE CRETACEOUS SYSTEM

The topmost bedrock in northwestern lowa and in much of the western and southwestern part of the State is that of the Creaceous system. 
Extent. The extent of the area underlain with the system is not certainly known because of the lack of outcrops. The solid Cretaceous area of northwestern Iowa is believed to include all or some part of Buena Vista, Cherokee, Clay, Crawford, Dickinson, Emmet, Harrison, Ida, Kossuth, Lyon, Monona, O'Brien, Osceola, Palo Altō, Plymouth, Pocahontas, Sac, Sioux and Woodbury Counties.

Another large irregularly shaped area of more than 1200 square miles extent underlies parts of Adair, Audubon, Calhoun, Carroll, Cass, Greene, Guthrie and Sac Counties. Another area of several hundred square miles extends irregularly over Adams, Cass, Mills, Montgomery and Pottawattamie Counties. Other small isolated areas are believed present in Adams, Kossuth, Montgomery and Page Counties. There may be other small areas elsewhere beneath the mantle, and it is recognized that areas mapped as isolated may be connected, and that areas mapped as solid may have many places from which the system is absent. The thickness ranges up to several hundred feet, but over much of the area is believed to be less than 100 feet.

General stratigraphy and structure. The system in Iowa is made up of interbedded clastic and limy sediments, including soft buff and white sandstone and siltstone, buff conglomerate ("peanut gravel"), gray and white sandy and silty shale and clay, calcareous clay and marl, and soft limestone and chalk.

The northwestern Iowa area, believed to include the Dakota, Graneros, Greenhorn and Carlile formations, contains considerable thicknesses of shaly and limy beds in the upper part, with the sandy and gravelly beds of the Dakota at depth. The other areas are comprised chiefly of weakly cemented sandstones and conglomerates and lesser amounts of gray clay and shale, all of the Dakota formation:

The detailed stratigraphy of the system is not well known over much of the area, because of the generally thick mantle of glacial clay and loess, and the absence of outcrops. Well records have furnished much of the available information.

The beds rest unconformably upon the underlying rocks and have a regional dip of a few or several feet per mile to the northwest. Reversals of the dip are probably present in places.

Uses. Shale and clay of the system in Iowa have proven suitable for the manufacture of ceramic wares, particularly of heavy clay products. They have been used at several places, but at present are used only in the vicinity of Sioux City. 
The occurrence and relations of Cretaceous shales and clays will be described for only a few of the counties where they occur. Those selected are counties where the beds are reasonably well known, or have been used, or have had attention attracted to them because of the known occurrence of shale and clay.

Adams. Beds of the Dakota formation form the top of the bedrock beneath areas totalling many square miles in the western part of the county, including the following township areas:

The northwestern part of Lincoln.

Central, western and southern Douglas.

Northern Nodaway.

There are many outcrops,"11 some of them meager, particularly in Douglas Township. Wood recognizes two units, "a lower-one consisting almost entirely of fine-grained sandstone, and an upper one of coarser sandstone and bright-colored clay." Other outcrops are described as containing clay with a high content of silt, and siltstone. A section from "south of the west quarter-section corner of section 19 Douglas township," believed to present the approximate average thickness, is given below:

Section: Douglas Townshin.

\begin{tabular}{|c|c|}
\hline Member & Description \\
\hline 4 & $\begin{array}{l}\text { Till, dark gray, unoxidized, unleached, with scattered } \\
\text { lime concretions, and definite layer of concretionary } \\
\text { lime marking contact with the bed, below. ........................... }\end{array}$ \\
\hline 3 & $\begin{array}{l}\text { Sandstone, brown, coarse-grained, some lenses con- } \\
\text { glomeritic, grains of quartz, iron oxide, and reddish } \\
\text { brown oxidized shale. }\end{array}$ \\
\hline 2 & $\begin{array}{l}\text { Shale, silty, and siltstone, light gray to drab, mas- } \\
\text { sive, with brown ferruginous concretions and thin } \\
\text { layers, and a few thin lenses of sandstone. Much of the } \\
\text { ferruginous concretionary material is derived from or } \\
\text { surrounds plant fragments. }\end{array}$ \\
\hline 1 & $\begin{array}{l}\text { Sandstone, buff, medium-grained; a strong massive } \\
\text { ledge. }\end{array}$ \\
\hline
\end{tabular}

The light-colored shales and clays, some silty and some lacking in silt, apparently are present in thicknesses of many feet in the Dakota areas of Adams County and presumably in adjoining Montgomery, Pottawattamie and Cass, but they are so interstratified with thick beds of sandstone and conglomerate that they are not believed to have potential value for industry of any size. It is believed that some at least are buff-burning and somewhat refractory, and these might be used for small scale operations. Depth of

51Wood, L. W., Geology of Adains County: Iowa Geol. Survey, vol. 37, pp. 316-321, 1941, 
overburden, in part sandstone, makes the shale, believed suitable for heavy clay products, of but little potential value.

Carroll. Beds of the Cretaceous system are believed to form the top of the bedrock beneath most of the eastern and northern parts of the county. ${ }^{\mathrm{B} 2}$ They are known from well records and from a few exposures along the Middle Raccoon River, the North Raccoon River, and Purgatory Creek.

Outcrops have been described as consisting principally of sandstone and conglomerate, with a smaller amount of light gray clay in the form of beds in thin seams. Large blocks of clay believed to have come from such Cretaceous occurrences in the area have been found' in the drift. From this it seems likely that deposits of this clay may exist in the rocks beneath the drift, possibly at the top. They may well be thin and irregular in thickness if similar in structure to light gray clay elsewhere in the Cretaceous of this part of Iowa.

Cass. Beds of the Dakota formation are believed to form the top of the bedrock beneath the mantle of a few townships in the northeastern townships and several in the southwestern townships. From outcrops and well records it is known that the Dakota of the county is almost entirely sandstone, although thin clay beds are present in some places. ${ }^{53}$ The clay is thought to be like that found near Red Oak, which burns to a buff color and is refractory. Judging by the known occurrences it does not exist in sufficient quantity or sufficiently free of overburden to be considered a potential resource.

Greene. Beds of the Dakota formation outcrop in Greene County and are believed to form the top of the bedrock of the western tier of townships. An occurrence of light gray clay northeast of Scranton in the NE1/4 sec. 26, Cedar Township, (T. 84 N., R. $32 \mathrm{~W}$.), has attracted attention during the past decade or two. The clay is in scattered exposures of Cretaceous rocks on both sides of a small valley tributary to that of the Raccoon River. The following is an approximate section of the exposures on the north side of the valley:

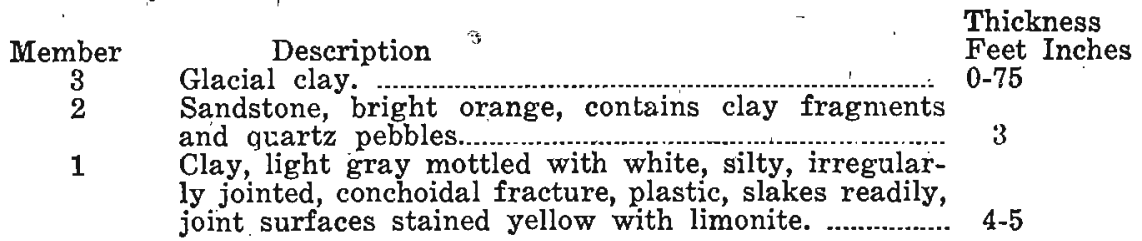

E2Bain, H. F., Geology of Carroll County: Iowa Geol. Survey, vol. 9, pp. 78-75, 1899. ESTilton, J. L., Geology of Cass County : Iowa Geol. Survey, vol. 27, pp. 203-209, 1917. 
The following is an approximate section of an outcrop on the side of the valley and a few rods from the one given above:

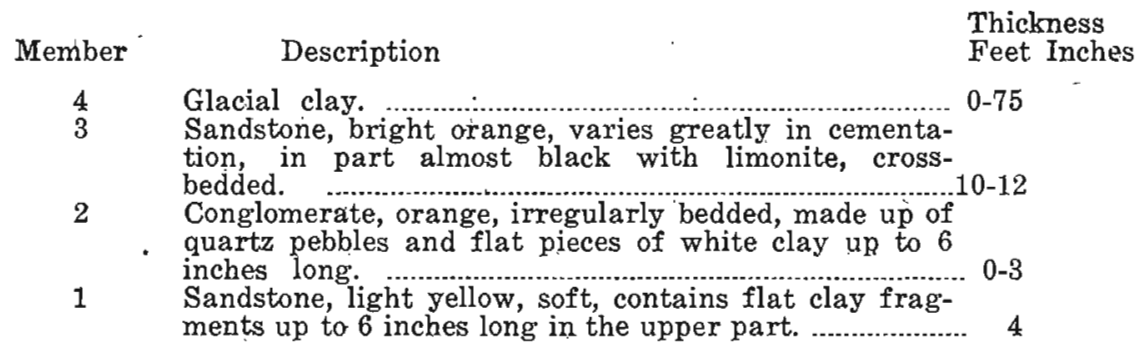

There are scattered exposures of conglomeratic sandstone and one of white clay nearby, and other outcrops of sandstone along the valley down to its confluence with that of the Raccoon River. Any other occurrences of white clay in this distance can only be rather small since otherwise they would show to some extent on the valley side.

Small amounts of the clay were used satisfactorily on a very small scale in the manufacture of art pottery by the Ames Art Pottery Co. of Ames and by a pottery company at Fort Dodge. The material is suited to the manufacture of cream or buff products such as pottery. These deposits are obviously so limited in quantity that they could not furnish the material for any sizeable industry. Other deposits of similar clay may be present elsewhere in the Dakota of Greene or surrounding counties. It is thought likely that any such deposits would be no more extensive than those described above.

Guthrie. Beds of the Dakota formation form the top of the bedrock beneath the mantle of most of Guthrie County with the exception of the eastern tier of townships. It is absent from strips up to approximately a mile wide along the course of the valley of the Middle Raccoon in Victory, western Highland and eastern Orange Townships; that of Brushy Fork in northern Seeley Township; that of the South Raccoon in southwestern Jackson and eastern Valley Townships; and that of Beaver Creek in northern Beaver Township.

The mantle of the county is generally thick but beds of the formation are exposed ${ }^{54}$ in places along both branches of the Raccoon River, Brushy Fork, Beaver Creek, Spring Branch and small tributaries of these streams. Bain reports thicknesses of as much as 100 feet. Most of this is sandstone and conglomerate of varying

*Bain, H. F., Geology of Guthrie County: Iowa Geol. Survey, vol. 7, pp. 451-459, 1897. 
degree of induration, but clay (or shale) up to 17 feet thick is interstratified in some places. Twenty feet of clay occurring near the fair grounds is stated by Bain to contain bands of sand. It is believed that some of this clay or shale is similar to that found irregularly interstratified with sandstone and conglomerate in outcrops in other counties which have been inspected in the course of this investigation. It is thought that while this clay is of relatively high quality it does not exist in Guthrie County in sufficient thickness, or sufficiently free of overburden or interstratified soft sandstone and conglomerate to make it a potential resource. Almost all of the outcrops are predominantly sandstone or conglomerate or both, and Bain states that the shale and clay members are the least widely distributed.

Montgomery. The Dakota formation is believed to form the top of the bedrock beneath most of Montgomery County with the exception of the southeastern corner and'most of the western half. It is absent from the greater part of West, Garfield, Jackson and Scott and from much of Lincoln, Sherman, Red Oak and Grant Townships.

There are numerous outcrops ${ }^{55}$ in a number of places along the larger valleys, and the formation is also known from well records. It is believed to average a few score feet in thickness. Conglomerate, sandstone, and shale or clay are present, and of these, sandstone is in the greatest amount and most widespread. The overlying mantle of glacial clay and loess ranges up to as much as 160 feet in thickness and is thought to average approximately 75 feet.

The shale or clay has thus far been found below the sandstone or in lenses within it. In some of the occurrences it is a light cream, drab or gray in color, has a conchoidal fracture, slakes easily, and is plastic when wet. It burns to a light colored product at a high temperature and is therefore suitable for use in the manufacture of pottery and buff face-brick. Material from the formation was at one time used in the manufacture of pottery and by brick plants in the vicinity of Red Oak, but the pits from which it was secured have long since become obscured through disuse.

Two localities where the material outcrops were examined, one of them near the site of a pottery which once operated southeast of Red Oak. An approximate section of nearby exposures (fig. 12) on a small tributary of the Nishnabotna River in the SW $1 / 4$ sec. 27 , Red Oak Township, (T. 72 N., R. 38 W.), is given below. 1895 .

woLonsdale, E. H., Geology of Montgomery County: Iowa Geol. Survey, vol. 4, pp. 412-427, 


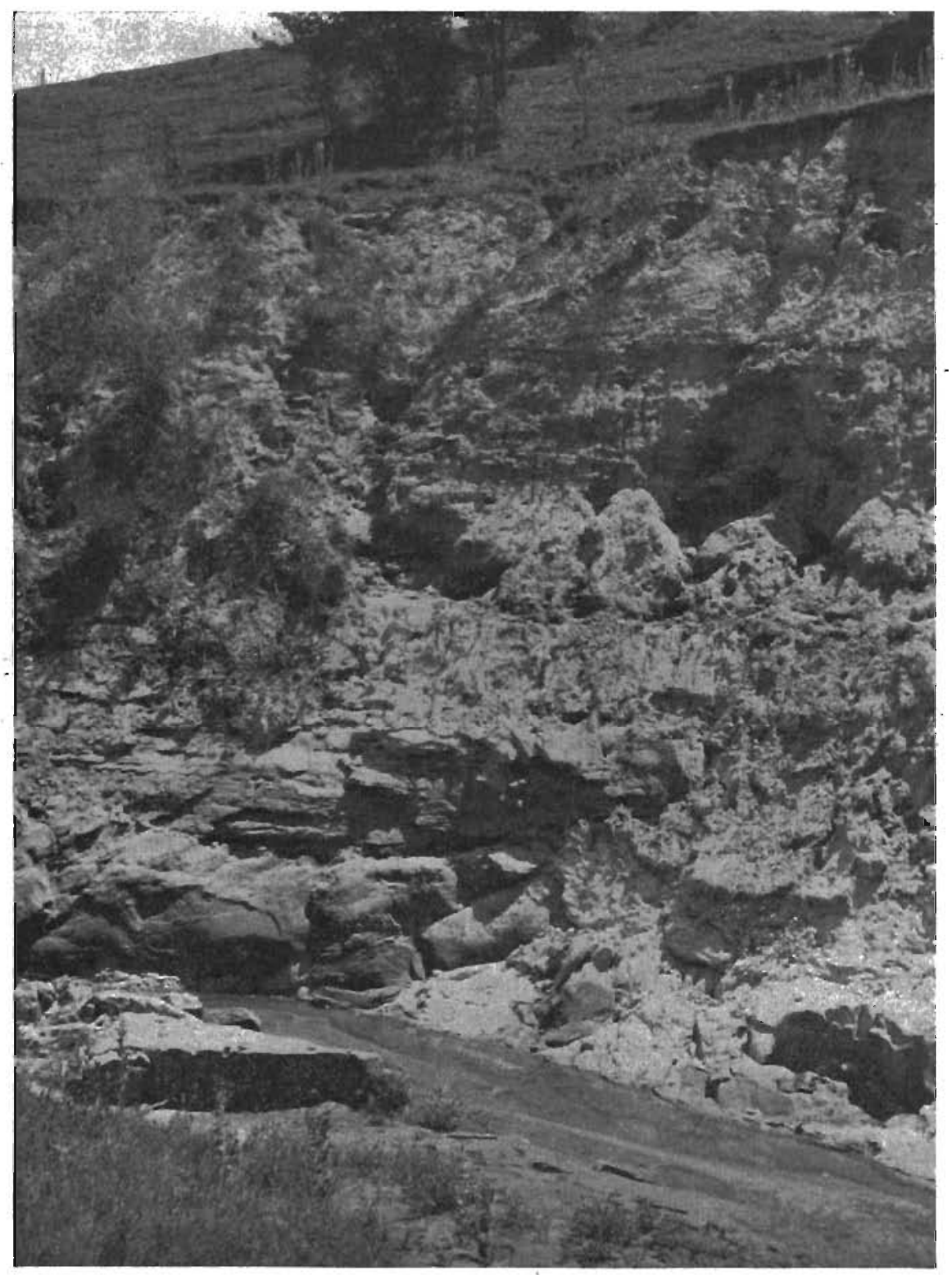

Figure 12. Interbedded Cretaceous sandstone and clay southeast of Red Oak, Montgomery County. 


\begin{tabular}{|c|c|}
\hline Member & Description \\
\hline $\begin{array}{l}6 \\
5\end{array}$ & $\begin{array}{l}\text { Sandstone, weathered. } \\
\text { Clay, gray, with numerous interbedded sandstone } \\
\text { layers. }\end{array}$ \\
\hline 4 & $\begin{array}{l}\text { Sandstone, cross-bedded, containing layers of light } \\
\text { gray clay up to several inchs thick, and fragments } \\
\text { of clay in places. }\end{array}$ \\
\hline 3 & $\begin{array}{l}\text { Sandstone, ferruginous, conglomeratic, containing } \\
\text { many clay fragments. }\end{array}$ \\
\hline $\begin{array}{l}2 \\
1\end{array}$ & $\begin{array}{l}\text { Clay, white and gray, sandy, plastic. (T) } \\
\text { Sandstone, white. }\end{array}$ \\
\hline
\end{tabular}

Scattered outcrops nearby are sufficiently different from the above to show that the section changes within short distances. Ceramic tests on member 2 of the above section, reported in the Tests on Iowa.Shales and Clays, show it to be a highly refractory, light buff-burning clay. It is in such small quantity, so uneven in distribution, and lies beneath such heavy overburden that its exploitation on a sizeable scale would not be profitable. Similar material secured from exposures near the present waterworks in Red Oak, probably was used by the pottery company which once operated in that city.

Some years ago attention was attracted to an occurrence of lightbuff clay on the east side of the valley of the Nishnabotna River in the SW $1 / 4$ sec. 17, Grant Township, (T. 71 N., R. 28 W.), on land owned by Mr. Pim. The clay is present beneath the bottom of a gravel pit of weakly cemented Cretaceous conglomerate, which had been removed to the level of the clay. The lower 5 feet of the conglomerate contains clay fragments in the form of slabs or blocks up to several feet in length and several inches in thickness. The buff clay is a few feet thick and is underlain by a similar clay, dull red in color. Presence of the deposit for a few hundred feet along the valley is indicated by a line of springs and seeps at about the same level. The clay is overlain by at least a few score feet of conglomerate and mantle. The thickness of the clay has not been determined, although beds of the Missouri series are believed to lie not many feet below the bottom of the pit. The clay greatly resembles in appearance that from the locality southeast of Red Oak, and if it resembles it in structure it is uneven in distribution and not more than a few feet thick. This clay also may be buff-burning and refractory, but its questionable thickness and its occurrence in association with the conglomerate and beneath thick overburden makes it of small potential value. This is also believed to be the case for any other occurrences of shale or buff-burning clay in the Dakota formation of Montgomery County. 
Plymouth.58 Beds of the upper part of the Cretaceous system as it is represented in Iowa are believed to form the top of the bedrock beneath all of Plymouth County. It is generally covered with mantle, much of it loess, scores of feet thick, and outcrops are confined almost entirely to the valley of the Big Sioux River and the lower parts of the larger tributary valleys. Particularly notable outcrops are at the confluence of the valley of Broken Kettle Creek with that of Big Sioux. The beds are also known from the numerous wells drilled through them to the Dakota aquifer in the lower part.

Sandstone is believed to predominate in the lower part of the system in Plymouth County, shale in the middle, and chalk and marl in the upper part. Some lignite is also present. Because of the slight regional dip to the northwest the lowest beds exposed are in the southern part of the area, but even these are in the upper part of the section.

The section described by Bain north of the confluence of Big Sioux and Broken Kettle Valleys in sec. 32, Sioux Township, (T. 91 N., R. 48 W.), is given to show the character of the Cretaceous in this county:

\begin{tabular}{|c|c|c|}
\hline Member & Description & $\begin{array}{l}\text { Thickness } \\
\text { Feet Inches }\end{array}$ \\
\hline 6 & $\begin{array}{l}\text { Limestone in thin beds, interstratified with } 4 \text { to } 10 \\
\text { inches of chalk. }\end{array}$ & 90 \\
\hline 5 & $\begin{array}{l}\text { Shale, buff, sandy, contains thin layers of sandstone } \\
\text { and ferruginous concretions. }\end{array}$ & 30 \\
\hline $\begin{array}{l}4 \\
3\end{array}$ & $\begin{array}{l}\text { Shale, dark blue to drab, fine-grained, argillaceous. } \\
\text { Sandstone, fine-grained, calcareous, light buff to } \\
\text { white. }\end{array}$ & 10 \\
\hline $\begin{array}{l}2 \\
1\end{array}$ & $\begin{array}{l}\text { Lignite. } \\
\text { Fireclay, white to. light gray, only slightly exposed, } \\
\text { found by digging. ........... }\end{array}$ & 1 \\
\hline
\end{tabular}

Bain believes the fire clay suitable for the manufacture of fire brick, but from the chemical analyses cited it would appear that they would not be as suitable as clays used elsewhere in the manufacture of refractory products.

This clay lies at approximately the river level; it has excessive overburden and a poor roof for drift mining. Member 4 is suitable for the manufacture of heavy clay products but also lies beneath excessive overburden. It is thought to lie beneath similar thicknesses elsewhere and thus to have but little potential value as a clay resource.

Pottawattamie. ${ }^{57}$ Beds of the Dakota formation are at the top

\footnotetext{
Bain, H. F., Geology of Plymouth County: Iowa Geol. Survey, vol. 7, pp. 328-335, 1897. oTUdden, J. A., Geology of Pottawattamie County: Iowa Geol. Survey, vol. 11, pp. 233-242, 1901.
} 
of the bedrock beneath the southeastern townships of Pottawattamie County. They are thought to underlie all of Center, Wright, Grove and Waveland; and parts of Valley, Lincoln, Belknap and Macedonia Townships. Boundaries of the formation are not definitely known because of the thick cover of glacial clay and loess, estimated to average 140 feet in thickness beneath the uplands.

The formation is known from a few outcrops and from well records. The outcrops are mostly sandstone overlain by shale, and well records show a similar section. Shale outerops in the NE1/4 sec. 36 , Wright Township, (T. 75 N., R. 38 W.), and sec. 1, Waveland Township, (T. 74 N., R. 38 W.). The general section given for the locality by Udden and believed to represent approximately the maximum thickness in the county is:

\begin{tabular}{|c|c|c|}
\hline Member & Description & $\begin{array}{l}\text { Thickness } \\
\text { Feet Inches }\end{array}$ \\
\hline & $\begin{array}{l}\text { Clay, grayish white or dark, weathers yellow and } \\
\text { red, occasional streaks of fine sand and dark carbona- }\end{array}$ & \\
\hline & ceous seams, contains concretionary lumps of siderite. & 37 \\
\hline 1 & Sandstone, fine-grained, uniform white or gray, part- & \\
\hline & 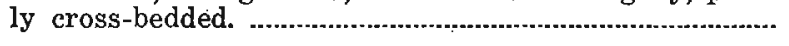 & 42 \\
\hline
\end{tabular}

Sac. ${ }^{58}$ Beds of the upper part of the Cretaceous system as it is represented in Iowa form the top of the bedrock of all Sac County. The mantle of glacial clay and loess averages a few score feet in thickness, and outcrops, of the bedrock are present only along Raccoon River in the vicinity of Grant City. Sandstone, shale, clay and chalk are present in the outcrops. The clay considered most promising as a ceramic material has a thickness of 15 feet and is described by MacBride as a fissle, drab-colored clay resembling fire clay in appearance. This material is said to have at one time been considered for use in brick manufacture, but so far as known was never used. The shales are undoubtedly suitable for heavy clay products manufacture and some of the clay may be of the buff-burning sort found elsewhere in the system in other western counties, but the heavy overburden would prevent their use by any sizeable industry.

Sioux. ${ }^{59}$ The beds of the Cretaceous system form the top of the bedrock beneath all of Sioux County. The mantle, drift and much loess, averages approximately 75 feet in thickness. Outcrops of the bedrock, few in number, are known only from the western part of

\footnotetext{
58MacBride, T. H., Geology of Sac and Ida Counties: Iowa Geol. Survey, vol. 16, pp. 526-531, 1906.

sowilder, F. A., Geology of Sioux County: Iowa Geol. Survey, vol. 10, pp. 108-117, 1900.
} 
the county along the valley of Big Sioux River. Shales are also exposed or close to the surface at two other localities, one in sec. 22, Logan Township, (T. 94 N., R. 48 W.), the other in sec. 12, Buncombe Township, (T. 95 N., R. 48 W.). Some, knowledge of the system in the county has also come from the records of wells drilled to the Dakota sandstone.

Shale, limestone and shale horizons occur in order above the sandstone. The upper shale is described by Wilder as an argillaceous, noncalcareous fissile variety, principally slate gray color but in part 'with shades between red and black. It contains gypsum but not in quantity sufficient to interfere with its use. The lower shale is harder and darker, grades into the limestone above, and is more calcareous. The upper shale was found suitable for use in the manufacture of bricks in a plant at Hawarden.

Woodbury. ${ }^{60}$ 'Beds of the Cretaceous system form the top of the bedrock beneath all of Woodbury County. The mantle of drift and loess averages at least a few score feet and outcrops of the bedrock are present only along the bluffs of the Missouri River in the vicinity of Sergeant Bluff and in Sioux City, and along the bluffs of the Big Sioux River north of Sioux City. Records of wells to the Dakota have also contributed to knowledge of the system in the county.

Sandstone, shale, and limestone make up the series which reaches a thickness of approximately 500 feet at Sioux City. Owing to the regional dip, higher and higher beds are present north from Sergeant Bluff along the valley of the Missouri River.

The lower part, the Dakota, has sandstone and shale, with shale predominating, near the bottom, in outcrops at Sergeant Bluff. Shale beds predominate higher in the section, as at Sioux City. Limestone and chalk are more abundant in the still higher part as shown by outcrops north of Sioux City.

The shales and clays have been used in the ceramic industry at Sioux City and Sergeant Bluff for many years.

The shale pit of the Sergeant Bluff plant of the Sioux City Brick and Tile Co. is northeast of Sergeant Bluff in sec. 30, Woodbury Township, (T. 88 N., R. 47 W.). Shale and clay have been taken from a distance of several hundred feet along the bluff, and in 1934 were being secured from an opening northwest of the plant (fig. 13).

${ }^{00}$ Bain, H. F., Geology of Woodbury County: Iowa Geol. Survey, vol. 5, pp. 242-298, 1896. 


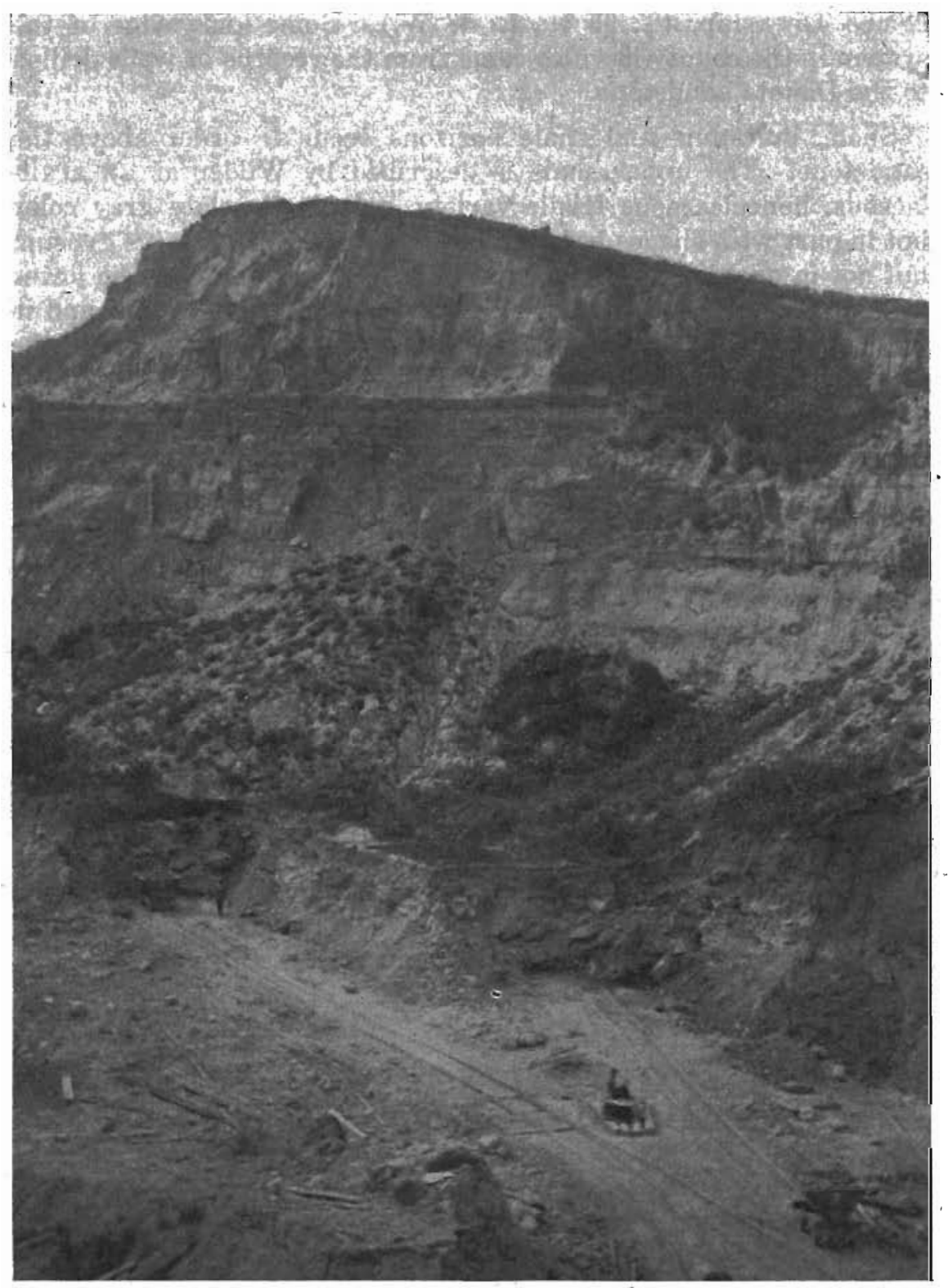

Figure 13. Shale pit of the Sioux City Brick and Tile Company, at Sergeant Bluff, Woodbury County. 
Section: Sioux City Brick and Tile Co., Sioux City, Woodbury County, (1933)

\begin{tabular}{|c|c|c|}
\hline Member & Description & $\begin{array}{l}\text { Thickness } \\
\text { Feet Inches }\end{array}$ \\
\hline $\begin{array}{l}6 \\
5\end{array}$ & 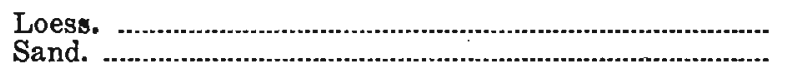 & $\begin{array}{l}4-30 \\
1-4\end{array}$ \\
\hline & Sandstone, light brown, well defined joints, massive & 00 \\
\hline 3 & & \\
\hline 2 & $\begin{array}{l}\text { stone. } \\
\text { Shale, light gray to dove gray, in part argillaceous, } \\
\text { but mostly containing silt, stratification indistinct, } \\
\text { joints irregular and dipping 45 degrees or less, con- } \\
\text { tains scattered plant impressions and fragments, par- } \\
\text { ticularly numerous in a zone near the top. (T) }\end{array}$ & $0-25$ \\
\hline 1 & $\begin{array}{l}\text { Shale, gray and gray brown, silty, a zone near the } \\
\text { middle contains much carbonaceous material. (T).... }\end{array}$ & \\
\hline
\end{tabular}

Members 1, 2 and 6 were the basis of the raw material being used in 1935. Where members 3 and 4 were of minor thickness and 5 absent the entire section was used.

The shale burns to a buff color and a hard ware can be produced from it. Loess is included in order to lower the burning temperature somewhat.

Shale and clay were formerly secured from a pit northeast of the plant and several rods from the present one. The exposures here are higher than those described above.

Section: Abandoned Pit at Sergeant Bluff, Woodbury County.

Member

Description

Thickness

Feet Inches

3 - Sandstone, brown, prominent jointing, 1 foot near the middle is hard and dark brown with limonite..........

2 Shale and shaly sandstone interbedded, in part strongly cemented with limonite.

1 Shale, argillaceous and sandy; dark gray from carbonaceous matter, grading to thin lignite beds toward the top.

25

3

23

Heavy clay-products plants have operated for many years in the Riverside district in the western part of Sioux City. Recently shale and clay have been secured from the east side of the valley of Big Sioux River in sec. 33 , T. 89 , N., R. 47 W. The section at the pit (fig. 14) operated in 1933 is giviven below:

Section: Sioux City Brick and Tile Co.,

Sioux City, Woodbury County, (1933)

Member
15
14

Description

Thickness

Feet Inches

Loess.

Sand and gravel. 
- Clay, buff, silty, weathered. (T)

Feet Inches

Shale, gray, silty, weathered.

6

Shale, buff, silty, weathered, contains gypsum crusts

and nodules.

Shale, banded light and dark gray, silty.

Sandstone, soft, argillaceous, banded with limoni-

tic streaks.

Sandstone, slabby, brown, calcareous.

Shale, gray, light and dark banded, silty, much like member 10 .

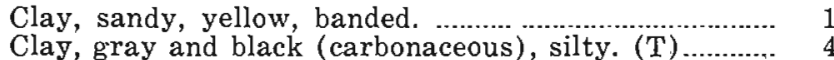

Clay, banded, dark. gray, contains considerable num-

ber of interstratified carbonaceous layers.

Lignite.

Sandstone, yellow.

Clay, banded light and dark, contains numerous

plant fragments and clay ironstone concretions. (T)

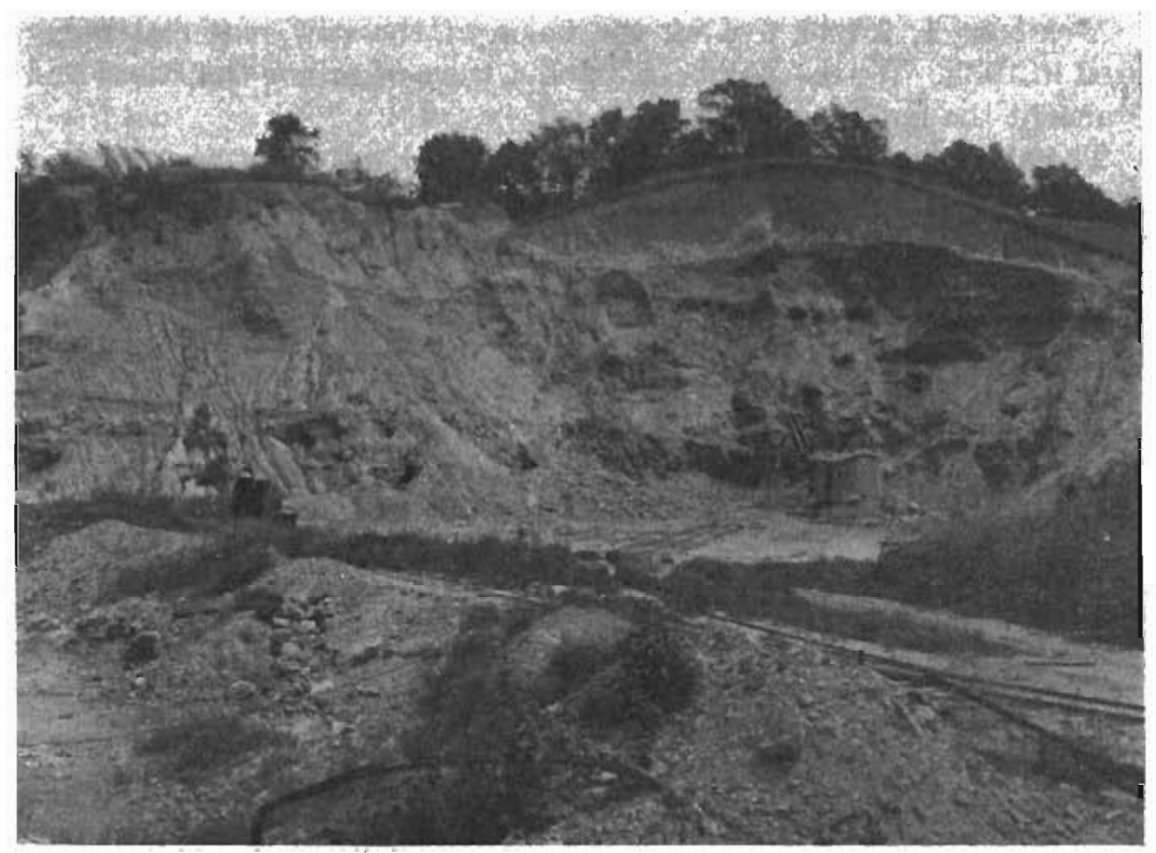

Figure 14. Shale pit of the Sioux City Brick and Tile Company of Sioux City, Woodbury County.

All members of the above up to 14 were used except the hard and unweathered sandstone of 8 and 9 . Quite definite stratification and much silty shale are notable features of the above section. The upper part of the section is notably weathered, and pyrite nodules and selenite crystals are abundant throughout.

Later a pit was opened 200 yards west of the above, believed to be somewhat lower than the previous section. 


\begin{tabular}{|c|c|c|c|}
\hline \multirow[b]{2}{*}{ Member ' } & $\begin{array}{l}\text { Section: Sioux City Brick and Tile Co., } \\
\text { Sioux City, Woodbury County. (1935) }\end{array}$ & \multirow{2}{*}{\multicolumn{2}{|c|}{ Thickness }} \\
\hline & Description & & \\
\hline 7 & & & \\
\hline 6 & Shale, slabby, sandy, weathered, contains gypsum as & 10 & \\
\hline & a white powder and in veinlets. & 5 & 6 \\
\hline 5 & $\begin{array}{l}\text { Shale or clay, much like member } 4 \text { but contains more } \\
\text { light colored }\end{array}$ & 10 & \\
\hline 4 & $\begin{array}{l}\text { Shale, carbonaceous, with white silty bands or } \\
\text { streaks, becoming less numerous toward top, where } \\
\text { it is principally black argillaceous shale, contains } \\
\text { gypsum in small crystals, zone about } 6 \text { feet from bot- }\end{array}$ & & \\
\hline 3 & $\begin{array}{l}\text { tom is limonitic, } \\
\text { Sandstone, soft, yellow, strongly cemented with lim-...................... }\end{array}$ & 16 & 6 \\
\hline & onite at top. & $3-4$ & \\
\hline 2 & $\begin{array}{l}\text { Shale, containing many sandy streaks, mostly finely } \\
\text { banded, contains sandy layers up to } 2 \text { inches strongly }\end{array}$ & & \\
\hline 1 & Shale, gray, no banding, starchy fracture, resembles & 0 & \\
\hline
\end{tabular}

Summarizing, the Cretaceous system of Woodbury County contains abundant shale suitable for heavy clay products, but these are not readily accessible except along the bluffs of Missouri and Big Sioux Rivers in the vicinity of Sioux City and Sergeant Bluff. Horizons particularly accessible in the vicinity of Sergeant Bluff are buff-burning and possibly somewhat refractory.

\section{CERAMIC TESTS ON IOWA SHALES AND CLAYS}

Many representative samples of shale and clay were collected in the course of the field study and 36, chosen for various reasons, were subjected to the tests recommended by the Standards Committee of the American Ceramic Society. ${ }^{61}$ Some of those tested were selected because they were considered typical of the material of certain pits, others because they were considereed typical of much of the material used from a formation or series such as the Des Moines, and still-others because they were stated to be markedly different in some property such as refractoriness. It is believed that the selection has been made so as to include a wide range of horizons and localities. These shales and clays were-noticeably different in appearance in outcrop, or upon megascopic examination-in color, content of silt, sand or carbonaceous material, in apparent plasticity, and in other characteristics.

The results of the tests are presented in table 4, and a description and an explanation of each of the tests will be given in the following pages, so that their purpose may be understood.

${ }^{1}$ Beecher, M. F., Report for the year 1922, Committee on Standards, Am. Ceramic Soc. Year Book, 1921-1922, Jour.. Am. Ceramic Soc., vol. 5, pp. 31-62, 1922. 


\section{TESTS ON UNBURNED CLAYS AND SHALES}

Time of slaking is intended to show the readiness of the material to fall apart in water, a matter which is of importance in its use, since generally clays are pugged or mixed with water prior to molding. The clay is mixed with 50 percent of finely ground flint, pugged and made into cubes. After these have been dried to $110^{\circ} \mathrm{C}$. they are cooled and submerged on a screen in water of $25^{\circ} \mathrm{C}$. The time required for all of the material to crumble and pass through the screen is the time of slaking.

Volume shrinkage is the shrinkage of volume which the wetted and molded clay undergoes upon drying at $110^{\circ} \mathrm{C}$. It has obvious value in that it discloses the extent to which clay ware will shrink in volume upon drying prior to burning. The volume shrinkage is arrived at by determining the difference between the volume of test bricks ( $11 \frac{1}{3}$ by $1 \frac{1}{8}$ by $1 \frac{1}{8}$ inches) when freshly made and again after drying. The volume is determined with a standard volumeter. It is expressed as a percent of the dry volume.

Linear shrinkage is the percent linear shrinkage as determined from the data secured in measuring the volume shrinkage and by the formula given below. A knowledge of the shrinkage is of importance to the user of clays inasmuch as it throws light upon the behavior to be expected of the clay ware in drying and in burning. -A clay with a high linear and volume shrinkage might be expected to crack in burning; one with a low linear and volume shrinkage might yield a product open in texture and low in strength. The percent linear shrinkage is derived from the following formula:

$$
a=\left[1-\sqrt[3]{\frac{1-b}{100}}\right] \times 100
$$

in which $b=$ percent volume shrinkage and $a=$ percent linear shrinkage.

Water of plasticity is the water present in a clay, when it is in a sufficiently plastic condition so that it is suitable for molding into ware. It is stated in percent. A knowledge of the amount of the water of plasticity is useful' in that it indicates the manner in which the clay will work, and the behavior to be expected of it in drying and burning. It is determined by mixing the clay to the proper consistency and making test pieces of a standard size ( $11 / 8$ by $11 / 8$ by $17 / 8$ inches). These are weighed in the moist condition, and again after drying to constant weight at $110^{\circ} \mathrm{C}$. The difference between the two weights constitutes the water of plasticity and is expressed in percent of the dry weight.' 
Shrinkage water is that portion of the water of plasticity which is driven off up to the point where shrinkage ceases. The amount of this is related to the possible cracking to be expected of the ware in drying. It is determined from the formula:

$$
\mathrm{t}_{1}=\frac{\mathrm{V}_{\mathrm{p}}-\mathrm{V}_{\mathrm{d}}}{\mathrm{W}_{\mathrm{d}}} \times 100
$$

wherein $t_{1}=$ the percent shrinkage water.

$\mathrm{V}_{\mathrm{p}}=$ the plastic volume in cubic centimeters.

$\mathrm{V}_{\mathrm{d}}^{\mathrm{p}}=$ the dry volume in cubic centimeters.

$\mathrm{W}_{\mathrm{d}}=$ the dry weight in grams.

Pore water is that portion of the water of plasticity which is driven off from the point where shrinkage ceases until the clay piece has reached approximately constant weight at $110^{\circ} \mathrm{C}$. A knowledge of this is useful in controlling the drying and burning of a clay. Since it is the difference between the water of plasticity and the shrinkage water, it is arrived at by subtracting the percent of shrinkage water from the percent of water of plasticity. It also is expressed in percent.

Transverse strength is the strength of the dried but unburned clay, expressed as the modulus of rupture in pounds per square inch. This is of obvious use to the clay products manufacturer inasmuch as it indicates the strength of the ware prior to burning and therefore the way in which it will stand up in the manufacturing process up to that point. For the purpose of this test, the clay is dried to $76^{\circ} \mathrm{C}$., mixed with an equal amount of dry silica sand, and then made to a plastic consistency and pugged by hand. It is molded into test pieces 7 inches long and 1 inch in cross section. These are dried, first in the air and finally in the drying oven to $110^{\circ} \mathrm{C}$., and then cooled in a dessicator. These test pieces are then broken in a suitable machine which determines the load at the time of rupture. The following formula is used:

in which

$$
M=\frac{3 P 1}{2 \cdot b d^{2}}
$$

$M=$ the modulus of rupture in pounds per square inch.

$P=$ the breaking load in pounds.

$1=$ the distance between knife edges in inches.

$\mathrm{b}=$ the breadth of the bar in inches.

$\mathrm{d}=$ the depth of the bar in inches.

Ten bars are broken and the average modulus of rupture reported. 


\section{TESTS ON BURNED CLAYS AND SHALES}

In order that the properties of the clay upon burning may be determined, test pieces ( $11 / 8$ by $1 \frac{1 / 8}{8}$ by $1 \frac{7 / 8}{8}$ inches) are prepared, dried, and the dry volume determined. They are then heated or burned in a refractory muffle, the temperature being controlled by means of Seger cones and by a thermocouple.

The use of these Seger pyrometric cones requires some explanation for those who are not familiar with clay ware manufacture. They are small cone-shaped test pieces used to determine the softening or fusing point of clay and clay ware. They are made of different mixtures of clay and fluxes, and the complete series of 64 cones represents a range in temperature from $590^{\circ} \mathrm{C}$. for cone 022 , to $2000^{\circ} \mathrm{C}$. for cone 42 . The numbers run from cone 022 , through 021,020 , etc., to cone 1 and then from cone 1 up to cone 42 . Each cone above cone 022 is approximately $20^{\circ} \mathrm{C}$. higher than the one below it. In use, as the softening or fusing temperature of a cone is reached it gradually bends over until its tip touches the base on which it rests. "The kiln is then stated to have reached the corresponding cone number. Similarly ware may be stated to have been burned to a certain cone number.

In this test work the temperature readings are reported in terms of cones. The heating is conducted at the rate of $45^{\circ} \mathrm{C}$. per hour from the start of the firing until a heat treatment is reached, and $20^{\circ} \mathrm{C}$. an hour from that point onward. A test piece is withdrawn at cone 010 and following that at intervals of two cones. The removal of the test piece is made quickly in each case, so that the furnace does not cool off appreciably. The test pieces as removed are covered with hot sand and when sufficiently cooled, are placed in a dessicator. They are then weighed (Wf) to $0.1 \mathrm{gram}$. Following this they are placed in distilled water, boiled for two hours, and cooled while still immersed in the water. The excess moisture is then removed and the piece weighed to $0.1 \mathrm{gram}$ (Sf): The volume (Vf) of the respective test pieces is also determined by measurement in a volumeter, using distilled water a's the liquid.

The apparent porosity is the porosity as shown by the amount of water taken up or retained when the specimen is boiled. It is expressed in percent and is determined with the use of the following formula :

$$
\mathrm{P}=\frac{\mathrm{Sf}-\mathrm{Wf}}{\mathrm{Vf}} \times 100
$$

where $\mathrm{P}=$ the percent apparent porosity. 
Sf $=$ weight of saturated fired test piece in grams.

$\mathrm{Wf}=$ weight of the fired test piece in grams.

Vf $=$ volume of the fired test piece in cubic centimeters.

This is of importance in showing the amount of apparent pore space and the solidity of the fired or burned products. It also indicates the stage attained in the burning process.

The volume change is the volume change developed in the process of burning or firing and is represented by the difference in volume between the burned and unburned test piece. A knowledge of this volume change developed at a succession of temperatures obviously shows the extent to which fusion and vitrification have proceeded. The dry volume of the unburned test piece is determined by soaking it in kerosene until saturated and then determining the volume in a volumeter using kerosene as the fluid. The volume of the burned test piece is also determined, as explained previously. The volume change is expressed in percent, based on the dry volume of the unburned test piece.

Apparent specific gravity is the specific gravity or weight per unit per volume of the water-impermeable portion of the test piece. It is thus the specific gravity of the solid material plus the sealed pores or cavities. Used in connection with bulk speeific gravity it throws light upon the degree of burning attained and on the amount of the closed cavities in the burned product. It is computed from the formula:

$$
G=\frac{W f}{V f-(\text { Sf }-W f)}
$$

in which $G=$ the apparent specific gravity.

Wf $=$ the weight of the burned test piece.

Vf $=$ the volume of the burned test piece.

$\mathrm{Sf}=$ the volume of the saturated burned test piece.

Bulk specific gravity is the specific gravity of the composite bulk; it may also be described as the specific gravity of the solid material plus the sealed pores or cavities plus the water-permeable pores. It is thus the weight per unit of exterior volume. As previously noted, this item is of value when used with the apparent specific gravity inasmuch as it gives an indication of the degree of burning attained and the nature of the openings in the burned product. It is computed from the formula:

$$
G_{b}=\frac{W f}{V f}
$$

in which $G_{0}$, is the bulk specific gravity. 
TABLE 4

Tests On Iowa Clays and Shales

\begin{tabular}{|c|c|c|c|c|c|c|c|c|c|c|c|c|c|c|c|c|c|}
\hline \multirow[b]{2}{*}{ Source of Clay } & \multicolumn{2}{|c|}{ TESTS } & \multicolumn{5}{|c|}{ ON UNBURNED CLAY } & \multicolumn{7}{|c|}{ TESTS ON BURNED CLAY } & \multirow[b]{2}{*}{ Remarks } & \multicolumn{2}{|c|}{ SAG TEST } \\
\hline & 空品 & 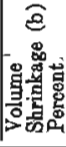 & 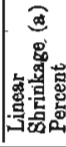 & 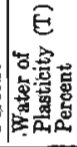 & 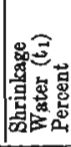 & 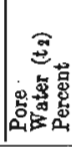 & 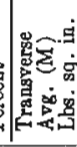 & 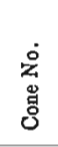 & 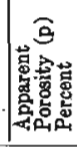 & 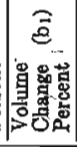 & 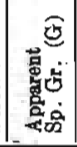 & | & $\begin{array}{l}\text { 总 } \\
\text { 总 } \\
\text { 尊 }\end{array}$ & 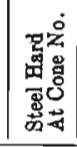 & & $\begin{array}{l}\dot{8} \\
\dot{0} \\
\dot{8} \\
0\end{array}$ & 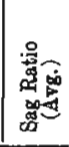 \\
\hline \multirow[t]{2}{*}{$\begin{array}{l}\text { Adel Clay Products Co... } \\
\text { Member } 1 \ldots \ldots \ldots \ldots \ldots\end{array}$} & 5.1 & 12.5 & 4.0 & 22.8 & 6.81 & 18.19 & 250.7 & $\begin{array}{l}06 \\
04\end{array}$ & $\begin{array}{l}31.6 \\
29.7\end{array}$ & $\begin{array}{r}1.06 \\
4.14\end{array}$ & $\begin{array}{l}2.61 \\
2.51\end{array}$ & $\begin{array}{l}1.79 \\
1.78\end{array}$ & $\begin{array}{l}17.07 \\
18.95\end{array} \mid$ & & \multirow[b]{2}{*}{$\begin{array}{l}\text { Burns light red. No tendency to warp } \\
\text { or craok. }\end{array}$} & & \\
\hline & & $\cdots \cdot$ (n... & $\cdots \cdots$ & $\left(\begin{array}{c}\cdots \cdots \\
\cdots \cdots \cdots \\
\cdots \cdots\end{array}\right.$ & & $\begin{array}{ll}\cdots \cdots \\
\cdots \cdots \\
\cdots \cdots \\
\cdots \cdots\end{array}$ & & $\begin{array}{r}02 \\
1 \\
2 \\
3 \\
5\end{array}$ & $\begin{array}{l}27.5 \\
28.7 \\
21.0 \\
19.8 \\
12.2\end{array}$ & $\mid \begin{array}{r}9.04 \\
4.61 \\
10.94 \\
13.84 \\
17.70\end{array}$ & $\begin{array}{l}2.69 \\
2.56 \\
2.50 \\
2.51 \\
2.41\end{array}$ & $\begin{array}{l}1.88 \\
1.82 \\
1.88 \\
1.98 \\
2.11\end{array}$ & $\begin{array}{r}14.61 \\
15.80 \\
10.85 \\
9.82 \\
5.75\end{array}$ & $\begin{array}{r}2 \\
\cdots \cdots \\
\cdots \cdots \\
\cdots \cdots\end{array}$ & & & \\
\hline \multirow[t]{3}{*}{$\begin{array}{l}\text { Adel Clay Products Co.... } \\
\text { Member } 2\end{array}$} & 12.1 & 30.4 & 9.3 & 23.9 & $i \bar{b} .6$ & 8.3 & 210.6 & $\begin{array}{l}06 \\
04 \\
02\end{array}$ & $\begin{array}{l}27.2 \\
22.3 \\
21.0\end{array}$ & $\begin{array}{r}7.6 \\
2.8 \\
10.8\end{array}$ & $\begin{array}{l}2.64 \\
2.49 \\
2: 34\end{array}$ & $\begin{array}{l}1.92 \\
1.95\end{array}$ & 14.1 & 02 & \multirow{3}{*}{$\begin{array}{l}\text { Burns light red. Does not warp, crack, } \\
\text { or swefl. }\end{array}$} & $\begin{array}{l}5 \\
01\end{array}$ & .016 \\
\hline & & & …... & (........ & $\cdots$ & …... & & $\begin{array}{r}02 \\
1\end{array}$ & $\begin{array}{l}21: 0 \\
18.0\end{array}$ & $\begin{array}{r}10.1 \\
8.7\end{array}$ & $\begin{array}{l}2.64 \\
.2 .50\end{array}$ & $\begin{array}{l}2.08 \\
2.05\end{array}$ & $\begin{array}{l}10.1 \\
8.8\end{array}$ & & & & \\
\hline & & & & (........ & & (n.... & $\ldots \ldots$ & $\stackrel{2}{3}$ & $\begin{array}{l}14.3 \\
14.1\end{array}$ & $\begin{array}{l}8.6 \\
7.9\end{array}$ & $\begin{array}{l}2.44 \\
2.34\end{array}$ & $\begin{array}{l}2.09 \\
2.01\end{array}$ & $\begin{array}{l}6.8 \\
7.1\end{array}$ & $\cdots$ & & & \\
\hline \multirow[t]{2}{*}{$\begin{array}{l}\text { Adel Clay Products Co... } \\
\text { Member } 4\end{array}$} & 7.45 & 18.3 & 6.7 & $\mid \begin{array}{l}32.3 \\
\cdots \cdots \\
\cdots \cdots\end{array}$ & $\begin{array}{l}\mathrm{i} 0.5 \\
\cdots \cdots \\
\cdots \cdots \\
\cdots\end{array}$ & 2.18 & 218.7 & $\begin{array}{r}5 \\
06 \\
04 \\
02 \\
1 \\
2\end{array}$ & $\begin{array}{l}14.0 \\
29.1 \\
24.5 \\
11.8 \\
17.4\end{array}$ & $\begin{array}{r}7.6 \\
9.8 \\
14.3 \\
26.4 \\
15.6\end{array}$ & $\begin{array}{l}2.46 \\
2.60 \\
2.29 \\
3.62 \\
2.49\end{array}$ & $\begin{array}{l}2.14 \\
1.85 \\
1.91 \\
2.16 \\
1.95\end{array}$ & $\begin{array}{r}6.6 \\
15.8 \\
12.9 \\
5.3 \\
9.2\end{array}$ & 02 & \multirow[t]{2}{*}{$\begin{array}{l}\text { Burng light red up to cone 2; vitrifies at } \\
\text { higher temperature and takes on } \\
\text { darker color. No tendeney to orack } \\
\text { or swell. }\end{array}$} & 01 & .0345 \\
\hline & & & & & & & & $\begin{array}{l}3 \\
3 \\
5\end{array}$ & $\begin{array}{r}6.6 \\
0.83\end{array}$ & $\begin{array}{l}32.5 \\
27.1\end{array}$ & $\begin{array}{l}4.59 \\
3.67\end{array}$ & 2.44 & $\begin{array}{l}2.7 \\
3.6\end{array}$ & & & & \\
\hline \multirow[t]{3}{*}{$\begin{array}{l}\text { Adel Clay Products Co.... } \\
\text { Member } 5\end{array}$} & 5.4 & 18.6 & 5.8 & 30.1 & 10.2 & 10.0 & 354.7 & $\begin{array}{l}06 \\
04\end{array}$ & $\begin{array}{l}31.6 \\
27.5\end{array}$ & $\begin{array}{l}2.15 \\
10.1\end{array}$ & $\begin{array}{l}2.50 \\
2.54\end{array}$ & $\begin{array}{l}6.71 \\
1.84\end{array}$ & $\begin{array}{l}18.0 \\
14.9\end{array}$ & 02 & \multirow[t]{3}{*}{ Burns light red. Vitrifies at cone 5.} & 01 & .0134 \\
\hline & & & $\cdots$ & $\cdots \cdots$ & $\cdots \cdots$ & (n)... & $\cdots \cdots$ & $\begin{array}{r}02 \\
1 \\
2\end{array}$ & $\begin{array}{l}18.9 \\
22.1\end{array}$ & $\left|\begin{array}{l}12.9 \\
18.4\end{array}\right|$ & $\begin{array}{l}2.35 \\
2.49 \\
2.4\end{array}$ & 1.01 & $\begin{array}{r}9.8 \\
11.4\end{array}$ & & & & \\
\hline & & & & $\cdots \cdots$ & $\because \cdots$ & $\cdots \cdot$ & & $\begin{array}{l}4 \\
3 \\
5\end{array}$ & 11.3 & $\left|\begin{array}{l}-3 \\
21.3 \\
23.5\end{array}\right|$ & $\begin{array}{l}\text { racked } \\
2.36 \\
2.28\end{array}$ & 2.09 & 0.4 & & & $\cdots \cdot$ & \\
\hline \multirow[t]{4}{*}{$\begin{array}{l}\text { Centerville Clay Products Co.......... } \\
\text { Member } 2\end{array}$} & 6.1 & 16.3 & 4.8 & 27.6 & $\begin{array}{l}3.6 \\
\end{array}$ & 19.0 & 164.5 & $\begin{array}{l}0 . \\
06 \\
04\end{array}$ & $\begin{array}{l}1.10 \\
34.7 \\
25.9\end{array}$ & $\begin{array}{l}23.0 \\
13.5 \\
12.7\end{array}$ & $\begin{array}{l}2.28 \\
2.96 \\
2.50\end{array}$ & $\begin{array}{l}2.23 \\
1.94 \\
1.83\end{array}$ & $\begin{array}{l}0.62 \\
17.9 \\
14.8\end{array}$ & 02 & \multirow[t]{4}{*}{$\begin{array}{l}\text { Burns light red. Tendency to crack and } \\
\text { swell above cone } 1 \text {. }\end{array}$} & $0 \mathrm{i}$ & .0682 \\
\hline & & & & {$[\ldots$,} & & 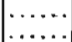 & {$\left[\begin{array}{l}\cdots \\
\ldots \ldots\end{array}\right.$} & $\begin{array}{r}02 \\
1\end{array}$ & $\begin{array}{l}9.7 \\
3.7\end{array}$ & \begin{tabular}{|l|}
25.0 \\
17.3
\end{tabular} \mid & $\begin{array}{l}2.44 \\
2.17\end{array}$ & $\begin{array}{l}2.18 \\
2.09\end{array}$ & $\begin{array}{l}4.4 \\
1.8\end{array}$ & $\ldots$. & & & \\
\hline & & & & & & ron & & 2 & Sprelle & & aracked & & & & & & \\
\hline & & & & & & & & & SwFole & & 2.32 & 2.28 & .79 & & & & \\
\hline
\end{tabular}

鰎 

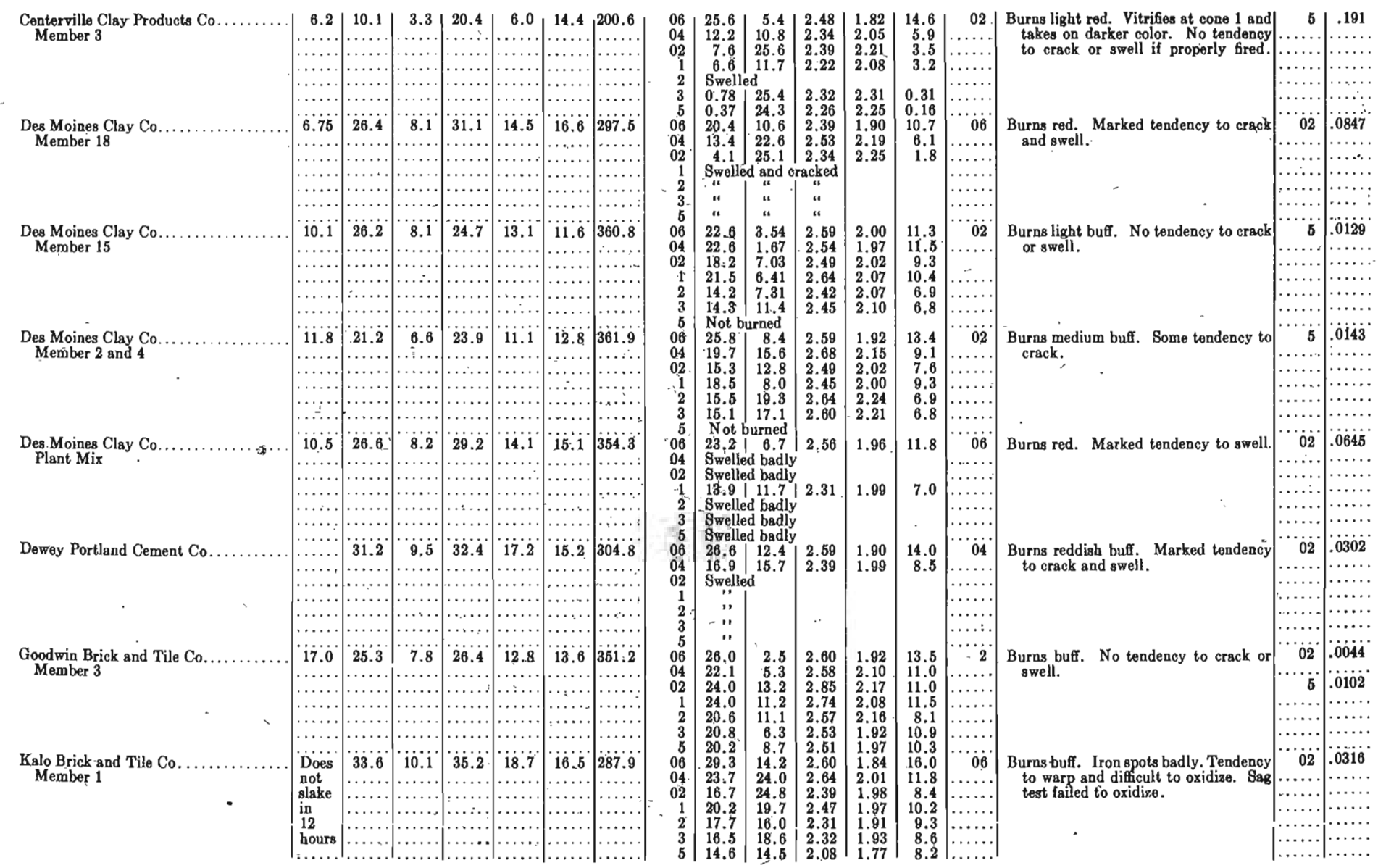

$$
\text { 䓒 }
$$


Tests On Iowa Clays and Shales-Continued

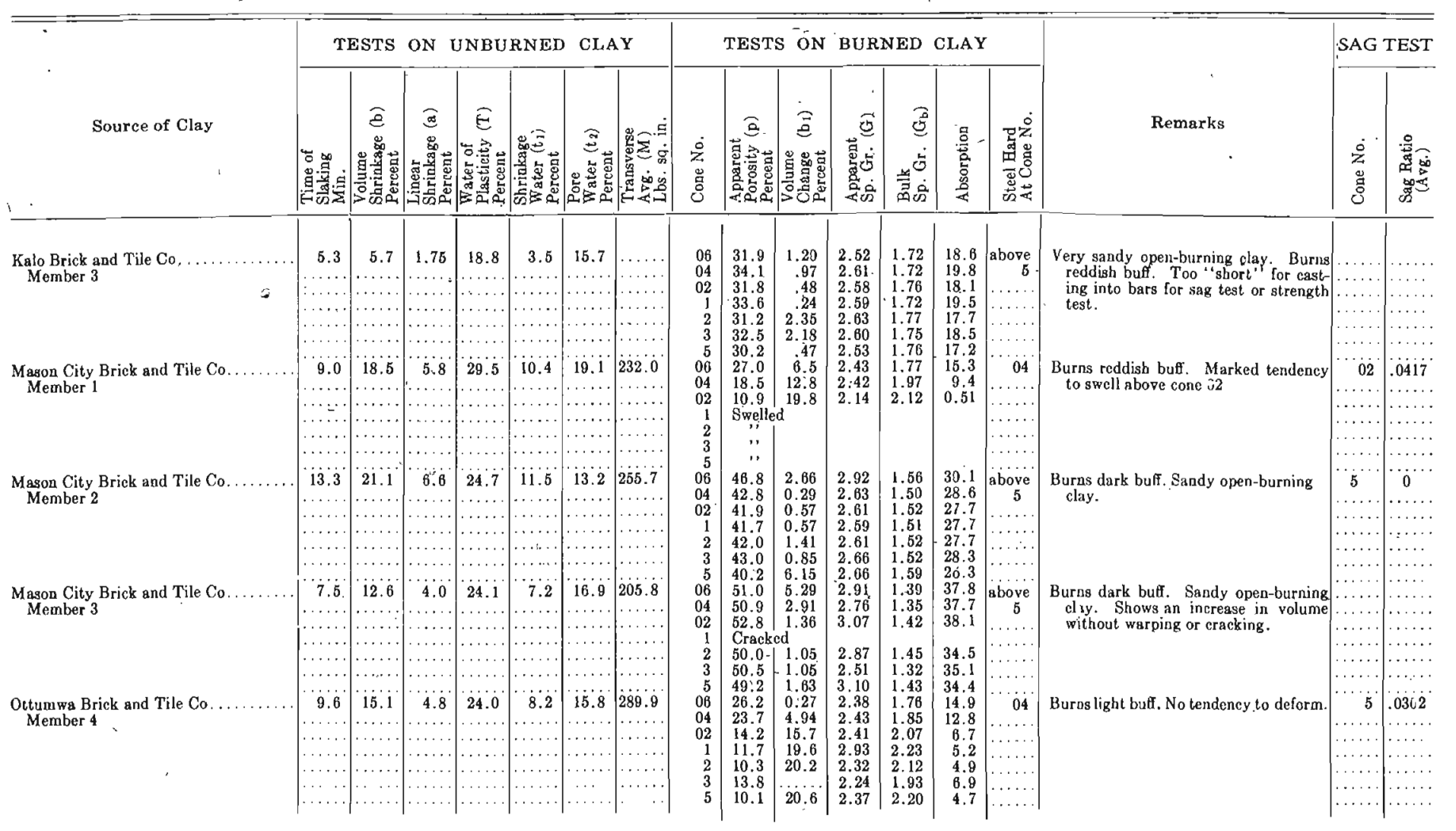



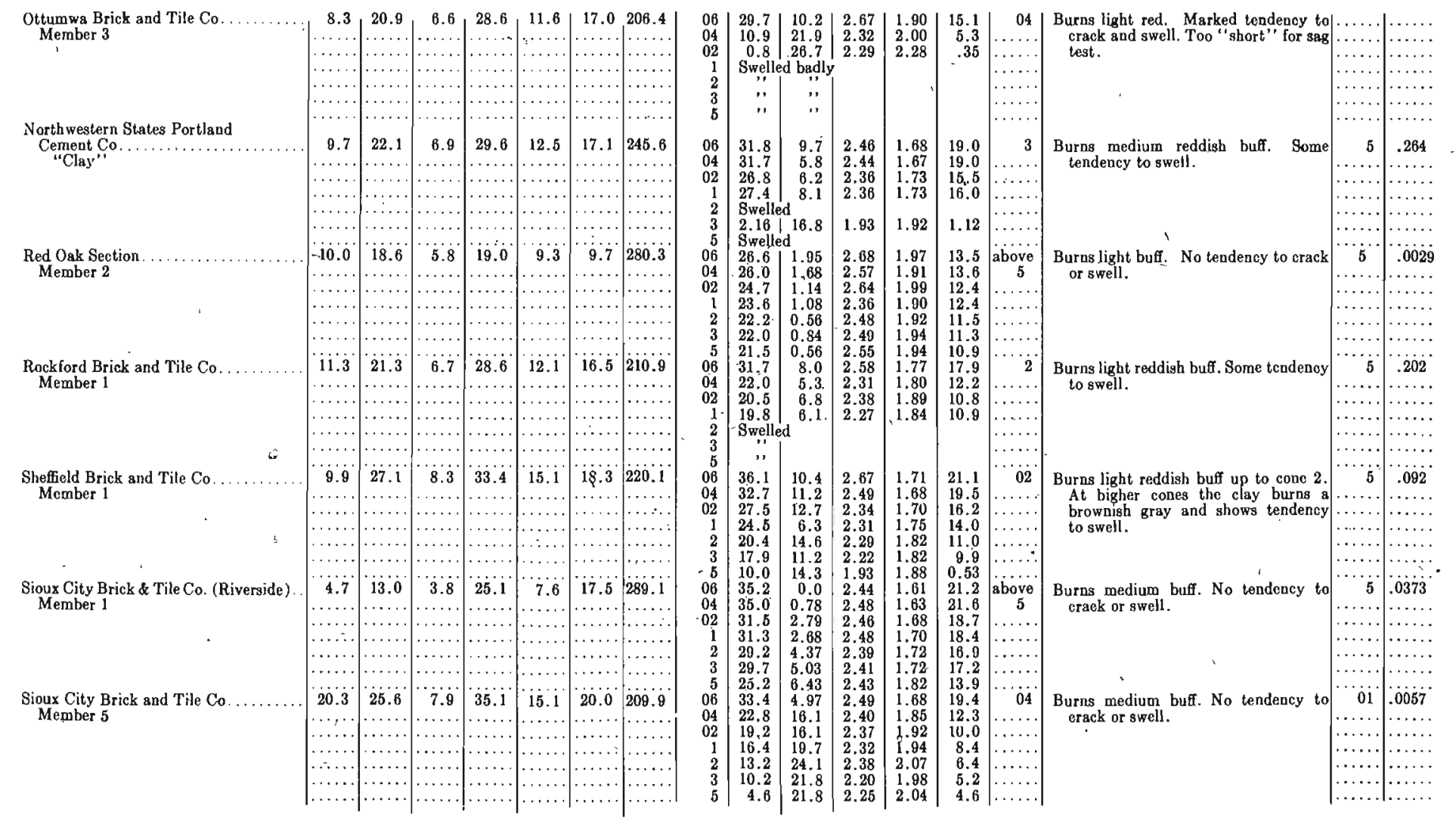

匍 


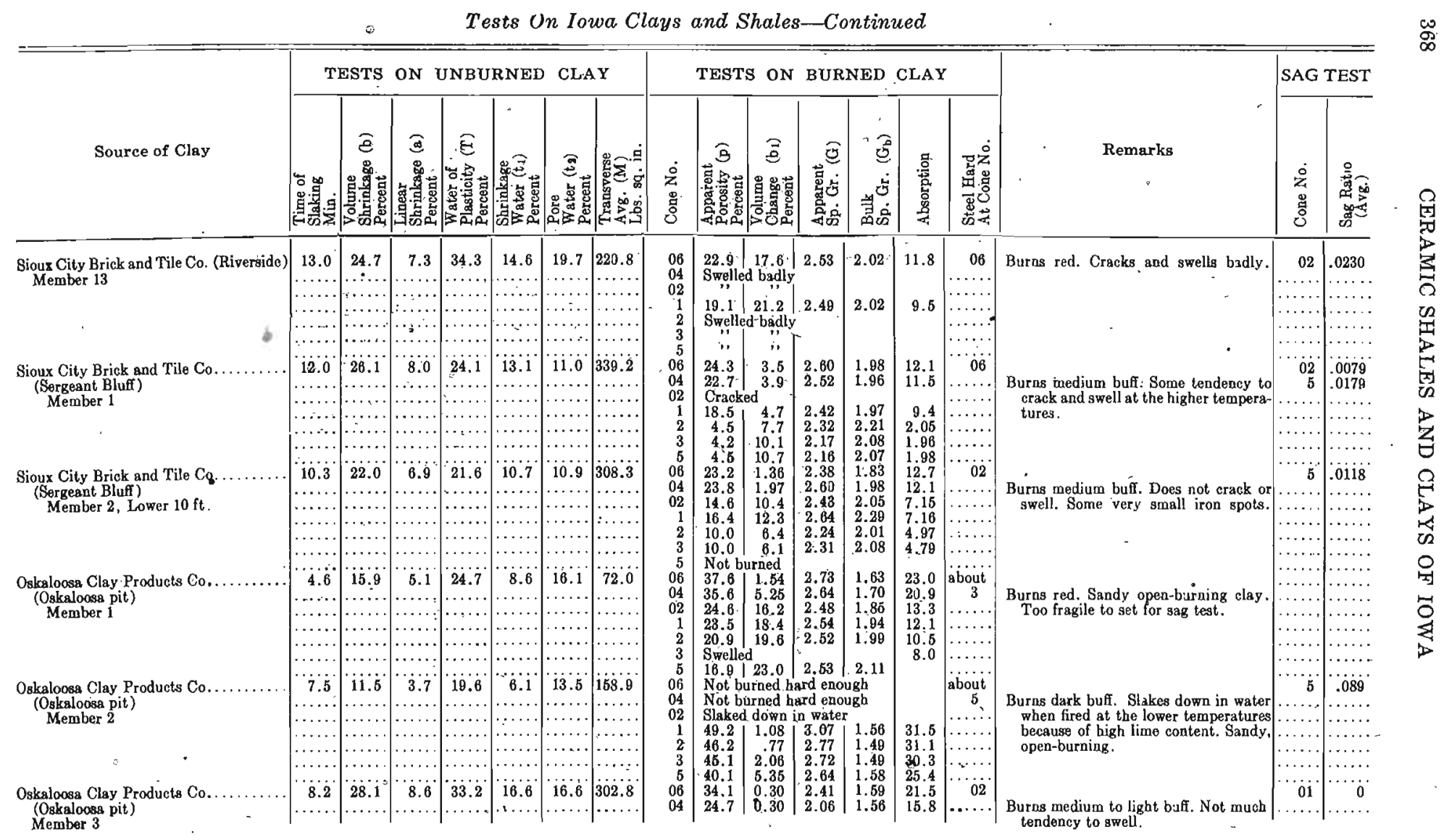




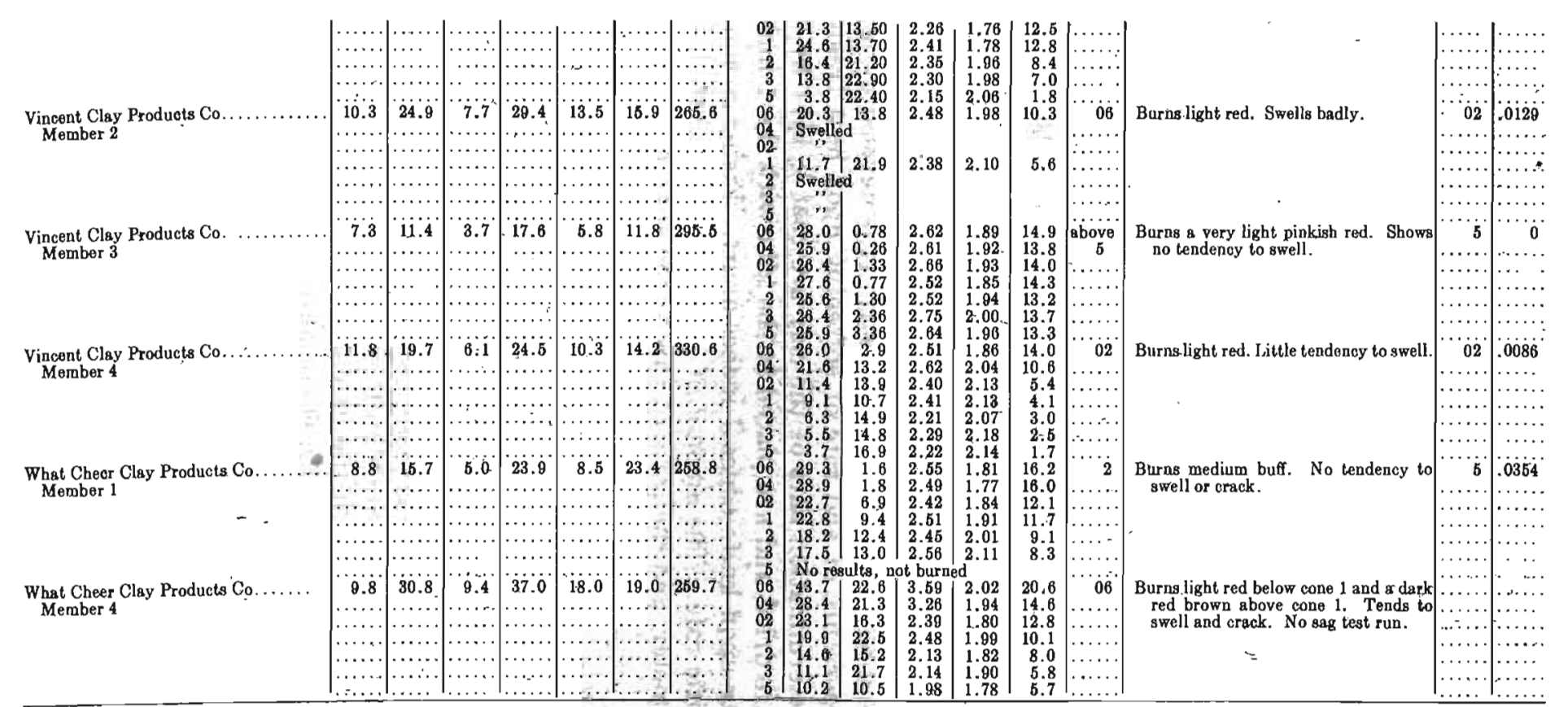

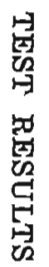
*These tests were ragde upon samples colected by the writer. Tests were made by Mr. A. L. Bock in the laboratories of the Department of Ceramic En-
gineering of Iowa State College, under the supervision of Prof. Paul E. Cox. The shales and clays included in this table are marked (T) where referred to elsewhere in the report. 
Absorption is reported as a percentage of the weight of the dry sample and represents the water absorbed by the test piece. It measures the degree to which burning has proceeded. It is obtaind by dividing the weight in grams of water absorbed by the weight in grams of the dry test piece.

Hardness. The point at which steel hardness is attained is reported under this heading. It is determined by testing the burned specimen with a piece of steel. It measures the extent or degree to which vitrification has been reached.

Color changes and behavior in burning. Under the heading of "Remarks" any other changes noted in the course of the burning are recorded. These may include color changes and such things as warping and cracking. Many of the clays and shales showed a tendency to swell or crack in these small-scale tests. Most of these would probably be found to fire without trouble under the more prolonged firing conditions used in commercial kilns. The behavior in these tests shows however that the possibility of trouble in this regard does exist.

Sag or warpage ratio is the ratio of the amount of deflection developed in burning to the length of a test bar. It is devised to determine the temperature of and rate of softening upon heat treatment. In this determination bars of the clay are cast $1 / 2$ by 1 by 9 inches. These are dried and are placed in the kiln with the 1-inch dimension resting upon knife edges 7 inches apart. Firing is conducted at a specific rate. The amount of deflection is measured in tenths of a millimeter, and the ratio of this to the span of 7 inches is computed.

Summary of tests. Standard tests have been conducted on these shales and clays, and results show them to range considerably in the various properties, but hardly more than would be expected of a range of shales and clays used in heavy clay products manufacture.

These tests, conducted upon both unburned and burned ware; are recognized by ceramists as giving as good an idea at least of the manufacturing properties of a shale or clay as can be secured in such small-scale tests, although the extent to which they indicate behavior in manufacturing practice is not agreed upon. The tests and their significance are well understood by manufacturers of ceramic ware and by ceramic engineers. 


\section{CHEMICAL ANALYSES OF IOWA SHALES AND GLAYS}

No chemical analyses have been made in the course of this study, but partial analyses made in the laboratories of the PennsylvaniaDixie Cement Co. of West Des Moines and the Northwestern States Portland Cement Co. of Mason City, and kindly furnished by the management of those companies, are listed in table 5. Sodium, potassium, water and carbon dioxide have not been determined, but the analyses are useful in that they disclose the percent of the other constituents.

Nos. 1 to 28 inclusive (table 5) are presumably from the Des Moines series and are considered representative of the materials used in the ceramic industry. Nos. 29 to 37 inclusive are from the Missouri series. They are not used in the ceramic industry, being generally unsuitable because of the high lime content. Nos. 1 to 37 inclusive are from the Pennsylvania-Dixie Cement Co., and 38 to 45 from the Northwestern States Portland Cement Co. The latter are from the Devonian beds in the vicinity of Mason City.

Chemical analyses of shales and clays are of limited use to a clay products manufacturer, since only the general physical properties can be deduced therefrom. A high silica content indicates the presence of silica in the form of silt or sand, and such material may be found to be lacking in plasticity and to burn at a high temperature. Iron, calcium, magnesium, sodium and potassium act as fluxes and tend to lower the burning temperature, particularly true of sodium and iron. Iron gives a red color to the product and calcium a buff color. High calcium and magnesium also generally mean a high carbon dioxide content, with resultant swelling upon burning, and the possible development of free lime.

TABLE 5

Analyses of Iowa Shales and Clays

No. Source and Description of Clay or Shale

$\mathrm{SiO}_{2} \quad \stackrel{\mathrm{Al}_{2} \mathrm{O}_{3}}{\mathrm{Ferent}_{2} \mathrm{O}_{3}} \quad \mathrm{CaO} \quad \mathrm{MgO}$

Standard Clay Products Co., Harvey,

Marion County.

1. Black shale, old pit $\begin{array}{lllll}72.4 & 13.8 & 3.6 & 0.3 & 0.6\end{array}$

$\begin{array}{llllll}2 . & \text { Clay with the appearance of fire clay.......... } 77.2 & 14.6 & 1.9 & 0.4 & 0.6\end{array}$

$\begin{array}{llllll}3 . & \text { Plastic clay underlying No. 2....................... } 65.9 & 18.9 & 3.4 & 0.3 & 0.8\end{array}$

Wabash Railroad cut near Harvey, Marion County.

4. Black shale.

United Brick and Tile Co., Carlisle, Warren County.

5. Yellow shale, 16 feet, (Top). ...................... 68.6

6. Pale blue-gray shale, 5 feet (Middle)......... 61.2

7. Blue-gray shale, 2 feet (Bottom) 
Goodwin Brick and Tile Co., southeast

Des Moines, Polk County.

8. Yellow sandy clay.

9. Red sandy clay east of No 8 (Top)

10. Gray clay (10 feet) and blue shale (10 feet)

11. "Cap" rock, 8 inches.

$76.2-10.8$

12. Hard gray shale, 5 feet

55.4

13. Black shale, 5 feet.

11.3

owa Pipe and Tile Co., Des Moines, Polk

County.

15. Shale, 6 feet, under upper "cap" rock

16. Shale, 6 feet, under second "cap" rock..... 52.6

Exposures on the Valley Drive on property

of Des Moines Water Works, Polk County.

17. Top 10 feet.

18. Blue shale, bottom of exposure, 10 feet.... 50.9

Road cut, $21 / 2$ miles west of West Des Moines,

Pollk County.

19. Yellow clay or shale, 13 feet (Top)

20. Blue-gray shale, 7 feet.

$66.3 \quad 11.5$

21. Blue-gray shale, 7 feet (Bottom)

67.2

Des Moines Clay Co., Des Moines, Polk County.

Hard blue-gray shale belov

23. Brittle blue-gray shale, above "cap" rock.

Pit at Van Meter, Dallas County.

60.00

61.2

68.9

10.8

5.7 $1: 4 \quad 1.0$

$\begin{array}{llll}18.4 & 11.7 & 2.2 & 1.7\end{array}$

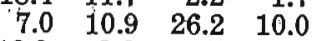

$\begin{array}{rrrr}18.3 & 8.0 & 1.5 & 2.0\end{array}$

$\begin{array}{llll}23.4 & 1.3 & 1.5 & 1.0\end{array}$

$\begin{array}{llll}11.5 & 9.3 & 1.4 & 1.0\end{array}$

24. Red shale below "cap" roek.

Vincent Clay Products Co, south of Fort Dodge,

Webster County.

25. Red granular clay.

U. S. Gypsum Co., Fort Dodge, Webster County.

26. Blue-gray and red shale, 6 feet (Top).

27. Dark gray-blue and red shale, 6 feet.

28. Light gray-blue and red shale, 6 feet (Top).

Quarry, $31 / 2$ miles north of Winterset, east of

69.5

19.2

$\begin{array}{lll}7.2 & 0.3 & 1.0\end{array}$

Highway 16, Madison County.

29. Black shale, 2 feet (Top)

30. Gray-blue shale, 9 feet

12.8

12.2

21.4

6.4

$\begin{array}{ll}0.6 & 2.0\end{array}$

1. Limy shale, 10 inches

$69.1 \cdot 12.4$

$68.4 \quad 16.1$

16.1

59.5

18.7

58.8

21.

21.0

22.4

53.1

21.6

5.5

$\begin{array}{ll}1.7 & 1.4\end{array}$

32. Limy shale, 14 inches. (Bottom) ....................... 23.8

Quarry $1 / 2$ mile west of Earlham, Madison County.

33. Six feet of shale at top of quarry. 66.3

17.7

4.1

4.0

$0.4 \quad 1.4$

Winterset, Madison County.

34. Sample of 28 cars blue and black shale beneath 18 feet of limestone. 51.6

17.1

15.8

$\mathbf{7 . 1}$

$\begin{array}{lll}3.1 & 3.2 & 2.3\end{array}$

$\begin{array}{lll}3.6 & 2.7 & 0.3\end{array}$

Quarry of Hawkeye Portland Cement Co.,

Earlham, Madison County.

35. Upper ledge of shale; blue shale.

36. Black shale. 57.5

13.7

$\begin{array}{lll}4.8 & 1.0 & 0.7\end{array}$

37. Yellow, limy shale. 50.1

12.8

$\begin{array}{ll}5.3 & 10.1\end{array}$

Northwestern States Portland Cement Co. shale 60.3

40.1

13.

10.9
8.9

5,2

3.0

pit, Mason City Cerro Gordo County.

38. "Blue" clay; used in the ceramic industry

at Mason City.

49.00

19.73

2.95

19.41

$50.20^{\circ}$

40. Same

53.88

20.74

3.99

4.62

20.84

42. Same

53.2

43. Same

54.28

20.75

20.43

3.04

4.65

44. Same

.56 .20

$21.11 \quad 3.89$

$\begin{array}{ll}7.72 & 3.87\end{array}$

$\begin{array}{ll}5.88 & 4.06\end{array}$

$1.32 \quad 4.15$

$2.64 \quad 3.80$

$2.96 \quad 3.54$

45. Same

$\begin{array}{ll}2.64 & 3.57\end{array}$

$2.80 \quad 3.60$

$2.44 \quad 2.79$ 


\section{INDEX}

\section{$\mathbf{A}$}

Abstract, 269

Adams County, Cretaceous system 347

Adel Clay Products Co., 273, 305; ceramic tests, 364 ; section, 305-308

Alluvial clay, 278

Ames Pottery Company, 349

Appanoose County, ceramic tests in. 364-365; Des Moines series in, 299. 300

Arey, M. F., cited, 338

Audubon County, Des Moines series in, 301; surface clay in, $285-288$

\section{B}

Bain, H. F., cited, 299, 310, 318, 324, $348,349,353,355$

Ballast, 272

Ball clay, 276

Beecher, M. F., cited, 359; lowa fire clays, 271

Bellevue Clay Products Co., 286

Benton County, Sheffield formation in, 294; surface clay in, 285

Beyer, S. W., cited, 271, 301, 311

Beyer, S. W. and Williams, I. A., eited, $285,286,310,318,322,337$

Beyer, S. W. and Young, L. E., cited, 323

Bissell, G. S., cited, 271

Boone County, Des Moines series in, 301; section in, 301

Brick, use, 272

Burned clays and shales, ceramic tests of, 362-370; absorption of, 370; apparent porosity, 362 ; apparent specific gravity of, 363 ; bulk specific gravity of, 363 ; color changes of, 370 ; hardness of, 370 ; sag or war-. page ratio of, 370 ; volume change of, 363

Butler County, Sheffield formation in, 294
C

Calhoun County, Des Moines series in, 302

Carlisle Brick and Tile Co., 373; section at, 338

Carroll County, Cretaceous system in, 348; Des Moines series in, 302

Cass County, Cretaceous system in, 348

Centerville Clay Products Co., 273; ceramic tests, 364-365; section at, 300 .

Ceramic glazed brick or tile, 275

Ceramic plants, distribution of, plate 1

Ceramic products, 301

Ceramic shales and clays, 301,302

Ceramic tests, 359-370; on burned clays and shales, $362-370$; summary of, 370 ; tabulation of, 364-369; on unburned clays and shales, $360-361$

Ceramic ware, 271

Cerro Goxdo County, ceramic tests in, 366-367; chemical analyses in, 372 ; Juniper Hill shale in, 290; Sheffield formation in, 294

Cerro Gordo member, 289, 292

Chemical analyses, 371 ; tabulation of, $371-372$

China, 373

Clay, alluvial, 278; ball, 276; chemical composition of, 281 ; composition of, 280 ; of Des Moines series, 296345 ; estuarine, 279 ; fire, 273,276 ; general geology of, 281; glacial, 278; lacustrine, 278; marine, 279; mineral composition of, 280 ; minerals of, 280 ; of Niagaran series, 288 ; origin of, 277; paper, 276; residual, 278 ; slip, 276; surface, $280,283-$ 285

Clay and shale, report of, 271 ; value of, 276

Clayton County, Maquoketa shäle in, 286 
Clermont Brick and Sand Co., 273, 287

Clinton County, 286; Des Moines series in, 302 ; Niagaran clays in, 288

Coal, 279

Common brick, 275

Crawford County, Des Moines series in, 302

Qretaceous, shales and clays of, 345 ; extent of, 346 ; stratigraphy of, 346 ; structure of, 346 ; uses of, 346

Cretaceous system, 345-359; in Adams County, 347; in Carroll County, 348; in Cass County, 348; in Greene County, 348-349; in Guthrie County, 349 ; in Montgomery County, 350352; in Plymouth County, 353; in Pottawattamie County, 353-354; in Sac County, 354; in Sioux County, 354-355; in Woodbury County, 355359

\section{D .}

Dakota formation, see Cretaceous system

Dallas County, ceramic tests in, 364; chemical analyses in, 372; Des Moines series in, 302-309; sections of Des Moines series in, 304, 305, 309

Davenport Brick and Tile Co., section at, 330

Definitions, 275

Delaware County, Maquoketa shale in, 286

Des Moines Clay Co., 273; ceramic tests, 365 ; chemical analyses, 372 ; section. at, $325-326$

Des Moines series, 283-345; in Appanoose County, 299-300; in Audubon County, 301; in Boone County, 301; in Calhoun County, 302; in Carroll County, 302; in Clinton County, 302; in Crawford County, 302; in Dallas County, 302-309; in Des Moines County, 309-310; in Franklin County, 310; in Greene County, 310; in Grundy County. 310; in Guthrie County, 310; in Hardin County, 311; in Harrison
County, 312; in Henry County, 312; in Humboldt County, 312; in Jackson County, 312; in Jasper County, 313; in Jefferson County, 313; in Johnson County, 314; in Keokuk County, 314-316; ' in Lee County, 316; in Louisa County, 316; in Lucas County, 316-317; in Madison County, 317-320; in Mahaska County, 318; in Marion County, 320; in Marshall County, 322; in Monroe County, 323; in Muscatine County, 324 ; outcrops in, 298-299; overburden on, 298; in $\mathrm{Po}$ cahontas County, 324; in Polk County, 324-328; in Poweshiek County, 328; in Sac County, 328; in Scott County, 329-330; in Shelby County, 330; in Story County, 330331; summary of, 345 ; in Van Buren County, 331-334; in Wapello County, 334-336; in Wàrren County, 337-338; in Washington County, 336-337; in Wayne County, 338; in Webster County, 338-345 ; in Wright County, 345

Des Moines series, shales ${ }^{-}$and clays, extent of, 296 ; relations of, 296 ; stratigraphy of, 297; structure of, 296 ; thickness of, 296-297

Dewey Portland Cement Co., 330; ceramic tests at, 365

Drain tile, 275

Dubuque County, Maquoketa shale in, 286

\section{$\mathbf{E}$}

Estuarine clay and shale, 279

\section{$\mathbf{F}$}

Face brick, 275

Fay, A. H., cited, 277

Fayette County, Maquoketa shale in, 286

Fire clay, 273, 276, 279

Floor brick, 275

Floyd County, ceramic tests in, 367; Juniper Hill shale in, 290

Foster, Monroe County, section at, 323 
Franklin County, ceramic tests in, Jasper County, Des Moines series in, 367; Des Moines series in, 310; 313

Sheffield formation in, 294

\section{, $\mathbf{G}$}

Galpin, S. L., cited, 288 , 310,332 ; refractory clay and shale, 271

Garrison Brick and Tile Co., 273, 284

Geologic map of Iowa, plate 1

Glacial clay, 278

Gladbrook Press Brick and Tile Co., 273,284

Goodwin Tile and Brick Co., 273, 325, 326 ; ceramic tests, 365 ; chemical analyses, 372 ; sections at, 303-306, 327

Gordon, C. H., cited, 332

Greene County, Cretaceous system in, 348-349; Des Moines series in, 310

Grundy County, Sheffield formation, 294

Guthrie County, Cretaceous system. in, 349; Des Moines series in, 310311

\section{$\mathbf{H}$}

Hancock County, Juniper Hill shale in, 290; Sheffield formation in, 294

Hardin County, Des Moines series in, 311

Harrison County, Des Moines series in, 312

Hawkeye Portland Cement Co., chemical analyses, 372 .

Henry County, Des Moines series in, 312; surface clay in, 285

Humboldt County, 312-313

\section{I}

Iowa County, Sheffield formation in, 29.5

Iowa Geological. Sưrvey, 269, 270

Iowa Pipe and Tile Co., 325, 326; chemical analyses, 372

Iowa Sewer Pipe and Tile Co., 274

$$
\text { J }
$$

Jackson County, Des Moines series in, 312

Jefferson County, Des Moines series in, 313

Johnson County, Des Moines series in, 314; Sheffield formation in, 295

Johnston Clay Works, 274, 339; section, 341

Juniper Hill member, 283, 289-293

\section{$\mathbf{K}$}

Kalo Brick and Tile Co., 274, 339; ceramic tests, $365-366$; section at, 324-343

Kaolin, 276

Keokuk County, ceramic tests in, 369; Des Moines series in, 314-316

Keyes, C. R., cited, 316

Kimballton Brick and Tile Co., 374

Kossuth County, Juniper Hill shale in, 290

\section{$\mathbf{L}$}

Lacustrine clay, 278

Ledges. State Park, 297.

Lee County, Des Moines series in, 316

Lehigh Portland Cement Co., Juniper Hill shale, 292

Lehigh Sewer Pipe Co., 274; section at, 344; Lime Creek formation, 283, 289-293; distribution of, 289

Loess, 279

Lonsdale, E. H., cited, 350

Louisa County, Des Moines series in, 316

Lucas County, Des Moines series in; 316-317

Lugn, A. L., cited, 316

\section{M}

Macbride, T. H., cited, 354

McHose, F. C. and Son, 274; section at, 331

Madison County, chemical analyses in, 372

Mahaska County, ceramic tests in, 368; Des Moines series in, 318

- Maquoketa formation, 283; distribu- 
tion of, 285 ; exposiures of, 286

Marine clay and shale, 279

Marion County, chemical analyses in, 371; Des Moines series in, 320-322

Marshall Gounty, Des 'Moines series in, $322-323$

Mason City Brick and Tile Co., 274, 289-290; ceramic tests, 366; Juniper Hill shale at, 290; section at, 290 291

Marston, A., cited, 271

Metcalf, R. W., cited, 276

Mineral production in Iowa, 271

Monroe County, Des Moines series in, 323-324

Montgomery County, ceramic tests in, 367; Cretaceous system in, $350-352$ Mortar mix, 27.5

Muscatime County, Des Moines series in, 324

Mystic coal, 300

\section{$\mathbf{N}$}

Nelson Clay Works, 274

Niagaran series, clays in, 283,288

Norton, W. H., cited, 329

North Cärolina, 278

Northwestern States Portland Cement Co., ceramic tests, 367 ; chemical analyses, 372; Juniper Hill shale at, 291-292

\section{$\mathbf{O}$}

Operators, 273-274

Origin of clay, 277

Oskaloosa Clay Products Co., 274; ceramic tests, 368; Harvey section, 320-322; Oskaloosa section, 319

Ottumwa Brick and Tile Co., 274; ceramic tests, 366-367; section at, 335-336

$$
\mathbf{P} \quad \text { s }
$$

Pàper clay, 276

Paving brick, 275

Platteville formation, 283

Plymouth County, Cretaceous system in, 353
Pocahontas County, Des Moines series in, 324

Polk County, ceramic tests in, 365; chemical analyses in, 372; Des Moines series in, 324-328

Portland cement, 275

Postrille Tile works, 287

Pottawattamie County, Cretaceous system in, 353-354

Pottery, 272, 311-312, 314

Poweshiek County, Des Moines series in, 328

Producers, clay products, $272-274$

\section{$\mathbf{R}$}

Railroad ballast, 275

Redfield Brick and Tile Co., 274

Red Oak section, ceramic tests at, 367

Residual clay, 278

Road surfacing, 275

Rockford Brick and Tile Co., 274; ceramic tests at, 367; Juniper Hill shale section, 292

Roxy Clay Works; 284

\section{$\mathbf{S}$}

Sac County, Cretaceous system in, 354; Des Moines series in, 328-329

Salt glazed brick or tile, 275

Sandstone, Des Moines series, 297, 302

Savage, T. E., eited, 312, 313

Schnurr, G. E., cited, 343

Scott County, ceramic tests in, 365 ; Des Moines series in, $\mathbf{3 2 9 - 3 3 0}$

Sedimentary rocks, $281-282$

Sewer brick, 275

Sewer pipe, use, 272

Shale, chemical composition of, 281; composition of, 280; Cretaceous, 345-359; of Des Moines series, 296345 ; estuàrine, 279 ; general geology of, 281; Juniper Hill, 289; Maquoketa, 285; marine, 279; mineral composition of, 280; of Sheffield formation, 293; of Upper Devonian series, 289

"Sheffield Brick and Tile Co., 274, 293- 
295 ; ceramic tests, 367

Sheffield formation, 283, 293-295; distribution, 293-294

Sioux City Brick and Tile Co., 274; ceramic tests, 367-368; sections at, 356-359

Sioux County, Cretaceous system in, 354-355

Slip clay, 276

Stainbrook, M. A., cited, 289, 293

Standard Clay Products Co., chemical analyses, 371

Stookey, S. W., cited, 328

Stoneware, 272, 276

Story County, Des Moines series, 330331

Straight, H. R., cited, 308

Structural clay tile, 275

Structure, 282

Surface clay, 279, 283-285; in Audubon County, 284; in Benton County, 284 ; in Henry County, 284; in Tama County, 284

\section{$\mathbf{T}$}

Tama County, 294; Sheffield formation in, 294; surface clay in, 285

Tester, A. C., geologic map of Iowa, 271

Tile, use, 272

Tilton, J. L., cited, 337, 348

Tilton, J. L. and Bain, H. F., cited, 317

Tyler, P. M., cited, 276

\section{U}

Udden, J. A., cited, $313,316,324,344$, 353

Unburned clays and shales, ceramic tests of, 360-361; linear shrinkagc of, 360 ; pore water of, 361 ; shrinkage water of, 361 ; time of slaking of, 360 ; transverse strength of, 361 ; volume shrinkage of, 360 ; water of plasticity of, 360
Underclay, 279, 313; in Des Moines series, 298; in Van Buren County, 332-333

Unglazed facing tile, 275

United Brick and Tile Co., 274, 309; chemical analyses, 371 ; section at, 309

U. S. Gypsum Co., chemical analyses, 372

\section{$\mathbf{V}$}

Value of clay and shale, 276

Van Buren County, Des Moines series of, 331-334; underclay in, 332-333

Vincent Clay Products Co., 274 ; ceramic tests, 369 ; section at, 340

\section{W}

Wapello County, ceramic tests in, 366367; Des Moines series in, 334-336

Warren County, chemical analyses in, 371; Des Moines series in, 337-338

Washington County, Des Moines series in, 336-337

Wayne County, Des Moines series in, 338

Webster County, ceramic tests in, 365366,369 ; chemical analyses in, 372 ; Des Moines series in, 338-339

Weems, J. D., cited, 271

What Cheer Clay Products Co., 274; ceramic tests, 369 ; section at, 315

Whittemore, O. J., cited, 341

Wilder, F. 'A., cited, 339, 354

Williams, I. A., cited, 271,313

Winneshiek County, Maquoketa shale in, 286

Winfield Brick and Tile Co., 274, 284

Winnebago County, Juniper Hill shale in, 290

Wood, L. W., cited, 347

Woodbury County, ceramic tests in, 367-368; Cretaceous system in, 355359

Wright County, Des Moines series in, 345 
